\title{
The Effects of Impurities on the Performance of Silicon Solar Cells
}

K. A. Yamakawa

September 1, 1981

Prepared for

U.S. Department of Energy

Through an agreement with

National Aeronautics and Space Administration

by

Jet Propulsion Laboratory

California Institute of Technology

Pasadena, California

(JPL PUBLICATION 81-76) 


\section{DISCLAIMER}

This report was prepared as an account of work sponsored by an agency of the United States Government. Neither the United States Government nor any agency Thereof, nor any of their employees, makes any warranty, express or implied, or assumes any legal liability or responsibility for the accuracy, completeness, or usefulness of any information, apparatus, product, or process disclosed, or represents that its use would not infringe privately owned rights. Reference herein to any specific commercial product, process, or service by trade name, trademark, manufacturer, or otherwise does not necessarily constitute or imply its endorsement, recommendation, or favoring by the United States Government or any agency thereof. The views and opinions of authors expressed herein do not necessarily state or reflect those of the United States Government or any agency thereof. 


\section{DISCLAIMER}

Portions of this document may be illegible in electronic image products. Images are produced from the best available original document. 


\title{
The Effects of Impurities on the Performance of Silicon Solar Cells
}

\author{
K. A. Yamakawa
}

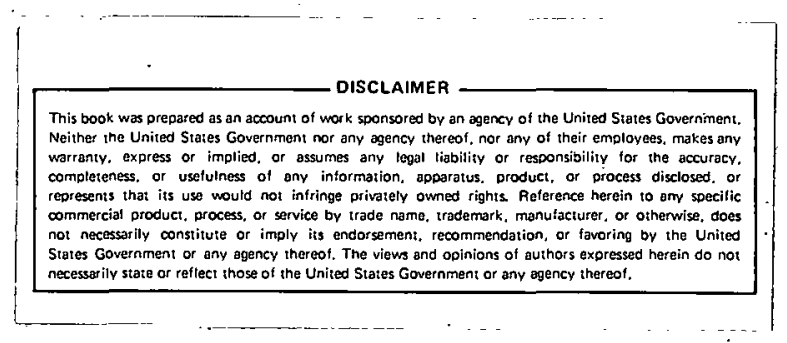

September 1, 1981

Prepared for

U.S. Department of Energy

Through an agreement with

National Aeronautics and Space Administration

by

Jet Propulsion Laboratory

California Institute of Technology

Pasadena, California 
Prepared by the Jet Propulsion Laboratory, California Institute of Technology, for the Department of Energy through an agreement with the National Aeronautics and Space Administration.

The JPL Flat-Plate Solar Array Project is sponsored by the Department of Energy (DOE) and forms part of the Photovoltaic Energy Systems Program to initiate a major effort toward the development of cost-competitive solar arrays.

This report was prepared as an account of work spunsured by the United States Government. Neither the United States nor the United States Department of Energy, nor any of their employees, nor any of their contractors, subcontractors, or their employees, makes any warranty, express or implied, or assumes any legal liability or responsibility for the accuracy, completencss or uscfulness of any information, apparatus, product or process disclosed, or represents that its use would not infringe privately owned rights.

Reference herein to any specific commercial product, process, or service by trade name, trademark, manufacturer, or otherwise, does not necessarily constitute or imply its endorscment, recommendations, or favoring by the United States Government or any agency thereof. The views and opinions of authors expressed herein do not necessarily state or reflect those of the United States Government or any agency thereof. 
The major factors that determine the tolerable concentrations of impurities in silicon feedstock for solar cells used in power generation are discussed in this report. It is concluded that a solar-grade silicon can be defined only for a specific manufacturing process. It is also concluded that it is the electrical effects, efficiency and resistivity, that are dominant in determining tolerable concentrations of impurities in the silicon feedstock. Crystal growth effects may become important when faster growth rates and larger crystal diameters are developed and used. 


\section{ACKNOWLEDGMENT}

This work was sponsored by the U.S. Department of Energy through an interagency agreement, DE-AI01-76ET20356, with the National Aeronautics and Space Administration (Task RD 152, Amendment 66).

The author gratefully acknowledges the Westinghouse Research and Development Center, and Hemlock Semiconductor Corporation as major contributors to the work performed and described in this report. 
CONTENTS

SUMMARY

I. INTRODUCTION .................... . . 1-1

II. PREPARATION OF MATERIALS ................. 2-1

A. IMPURITY SELECTION .................. 2-1

B. INGOT PREPARATION ................. 2-1

C. INGOT CHARACTERIZATION .............. 2-4

III. IMPURITY ANALYSIS ................... 3-1

A. INGOT IMPURITY CONCENTRATIONS ............. 3-1

B. UNINTENTIONALLY ADDED IMPURITIES ........... 3-1

IV. ELECTRICAi CHARACTERIZATION OF MATERIAL . . . . . . . . 4-1

A. Electrical MEASUREMENTS .............. 4-1

B. TEST SOLAR CELLS ................. . 4-1

C. SOLAR CELLS USING STANDARD COMMERCIAL PROCESS . . ...

V. SOLAR-CELL MODEL ..................... . . 5-1

A. MODEL APPROACH AND ASSUMPTIONS ...........

B. DERIVATION OF MODEL ................. 5-1

VI. EFFICIENCY CONSIDERATIONS FOR SILICON FEEDSTOCK . . . . . 6-1

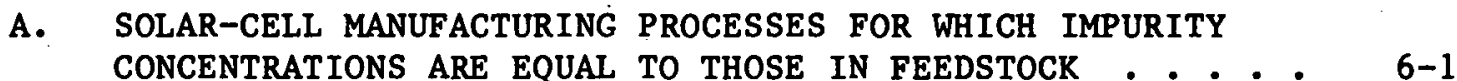

B. SOLAR-CELL MANUFACTURING PROCESSES WHERE REDISTRIBUTION

OF IMPURITIES OCCURS ............... . 6-7

VII. SILICON SOLAR-CELL IMPURITY EFFECTS SLIDE RULE . . . . • • . 7-1 SAMPle Calculation . . . . . . . . . . . . . . 7-1 
VIII. BORON AND PHOSPHORUS

IX. CRYSTAL STRUCTURE BREAKDOWN

$\mathrm{X}$.

CONCLUSIONS $10-1$

XI. REFERENCES

APPENDIX

A. NORMALIZED EFFICIENCY AS A FUNCTION OF THE CONCENTRATION OF EPECIFIC IMPURITIES IN UNITS OF NO

\section{Flgures}

2-1. Silicon Ingot Sampling ............... 2-5

5-1. Minority Carrier Lifetime versus Relative Short-Circuit Current . . . . . . . . . . . . 5-3

5-2. Variation in Electrically Active Impurity Concentration as a Function of the Metallurgically Added Impurity Content of As-Grown Ingots ............ 5-4

5-3. Normalized Open-Circuit Voltage as a Function of Normalized Short-Circuit Current for Impurity-Doped Solar-Cells Made on $4 \mathrm{ohm}-\mathrm{cm}$ Silicon . . . . . . . . 5-9

5-4. Normalized Efficiency as a Funcelon of Normalized Short-Circuit Current . . . . . . . . . . 5-10

6-1a. Impurity Concentration in Solar Cell versus Impurity Concentration in Units of $\mathrm{N}_{\mathrm{ox}}$, p-Base, a $/ \mathrm{cm}^{3} . . . . . . . . . . . . . .66=2$

6-1b. Impurity Concentration in Solar Cell versus Impurity Concentration in Units of $\mathrm{N}_{\mathrm{Ox}}$, p-Base, ppma ...... 6-3

6-2a. Impurity Concentration in Solar Cell versus Impurity Concentration in Units of $\mathrm{N}_{\mathrm{ox}}$, n-base, a/cm ${ }^{3} . . . .26-4$

6-2b. Impurity Concentration in Solar Cell versus Impurity Concentration in Units of $\mathrm{N}_{\text {ox }}$, n-base, ppma ...... 6-5

6-3. Normalized Efficiency as a Function of Impurity

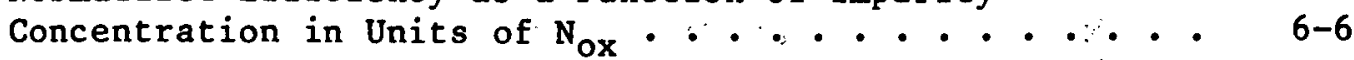

6-4. Normalized Efficiencies for Multiply-Doped 4 ohm-cm p-Base Solar Cells . . . . . . . . . . 
6-5. Impurity Concentration Buildup for Sequential

Replenishment . . . . . . . . . . . . . . . .

6-6. Impurity Concentration Buildup for Continuous

Replenishment ................ 6-14

6-7a. Impurity Concentration in Feedstock versus Impurity

Concentration in Units of $\mathrm{N}_{\mathrm{ox}}, \mathrm{a} / \mathrm{cm}^{3}$

(Czochralski Growth) ................

6-7b. Impurity Concentration in Feedstock versus Impurity

Concentration in Units of $\mathrm{N}_{\mathrm{ox}}$, ppma

(Czochralski Growth)

7-1. Slide Rule (a - Front, b - Back) .......... 7-2

7-2. Scale Set for Fe for Case I at (A). Impurity

Concentration in Solar Cell for 10\% Degradation

in Efficiency $7 \times 10^{-3}$ ppma .......... . . . . .

7-3. Scale Set for Five Replenishments for Case II at (A).

Impurity Buildup Factor of 46 is Obtained at (B) . . . 7-3

7-4. Scale Set at Impurity Buildup Factor of 46 for Fe at (A). Impurity Concentration in Feedstock for 10\% Degradation in Efficiency, 25 ppma at (B) for Case II . . . . . 7-4

8-1. Resistivity of Silicon at $300^{\circ} \mathrm{K}$ as a Function of Acceptor or Donor Concentration . . . . . . . . 8-2

8-2a. Resistivity as a Function of Fraction of Melt Solidified for Boron-Doped Silicon Compensated with Phosphorus (1 ohm $=\mathrm{cm})$. . . . . . . . . .

8-2b. Resistivity as a Function of Fraction of Melt Solidified for Boron-Doped Silicon Compensated with Phosphorus $(0.5 \mathrm{ohm}-\mathrm{cm})$.......... $8-4$

8-2c. Resistivity as a Function of Fraction of Melt Solidified for Boron-Doped Silicon Compensated with Phosphorus $(0.3 \mathrm{ohm}-\mathrm{cm})$. . . . . . . .

8-2d. Resistivity as a Function of Fraction of Melt Solidified for Boron-Doped Silicon Compensated with Phosphorus (0.1 ohm-cm) . . . . . . . . . 8-6

8-3 Phosphorus Buildup in Melt as a Function of the Ratio of the Volume of Crystal Grown to the Volume of the Melt......................

9-1 Measured and Calculated Values of the Critical Impurity Concentration, $\mathrm{C}^{\mathrm{L}^{*}}$, at the Start of Crystal Structure Breakdown . . . . ......... 
9-2. Impurity Concentration for Crystal Structure Breakdown as Functions of Pull Rate and Ingot Diameter . . . . . . 9-3

\section{Figures}

A-1.

through Normalized Efficiency as a Function of Impurity.

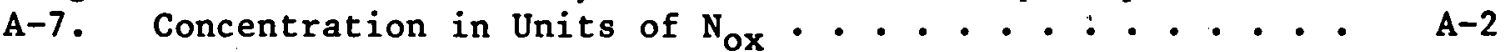

\section{Tables}

2-1. Typical Impurity Concentrations in Metallurgical

Silicon ..................... 2-1

2-2. Impurity Matrix ............... .... 2-2

2-3. Polycrystálline Silicon Analysis ............ 2-3

2-4. Characteristics of Dopant Materials . . . . . . . 2-4

3-1. Typical Detection Limits of Analytical Techniques

Employed in this Investigation ......... 3-2

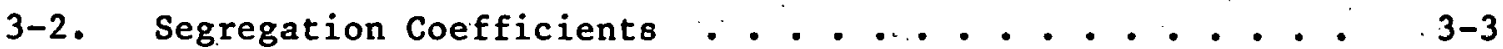

3-3. Neutron Activation Analysis for Impurities Not

Intentionally Added . . . . . ........ 3-4

5-1. Mode1 Coefficients for Singly-Doped, p-Base

5-2. Model Coefficients for Singly-Doped, n-Base
Solar Cells $5-6$

6-1. Impurity Concentrations for Multiply-Doped Ingots

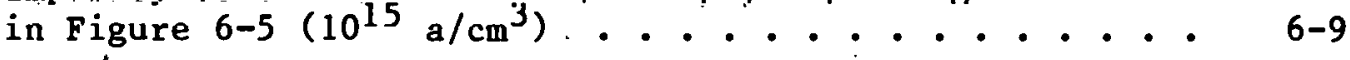


The major factors that determine the tolerable concentrations of impurities in silicon feedstock for solar cells used in power generation are the effects of: (1) impurities on the efficiency of solar cells; (2) boron and phosphorus on resistivity and ingot yield; and (3) total impurity concentrations in the silicon feedstock on crystal growth.

The effects of impurities on the diffusion length and efficiency, are species-dependent. The effects are most severe for the elements $\mathrm{Ta}, \mathrm{Zr}, \mathrm{Mo}$, $\mathrm{W}, \mathrm{Nb}, \mathrm{V}$ and $\mathrm{Ti}$ where concentrations in the range of $10^{-6}$ to $10^{-5}$ parts per million atomic (ppma) produce degradations of 5 to $10 \%$ in solar-cell performance; however, $\mathrm{Cr}, \mathrm{Mn}, \mathrm{Fe}, \mathrm{Co}, \mathrm{Al}, \mathrm{Ni}$ and $\mathrm{Cu}$ have successively smaller effects. For $\mathrm{Cu}$, the impurity concentration for a $10 \%$ degradation in cell performance is about 10 ppma. The segregation coefficients of these elements are small, in the range of $10^{-3}$ to $10^{-8}$, so that solar-cell manufacturing processes that include unidirectional freezing of silicon melt, under near equilibrium conditions (as in the Czochralski method), can relax the purity requirement of the feedstock material. At the same time, the limitation on the total impurity concentration in the silicon feedstock that prevents crystal structure breakdown must be considered. The tolerable impurity concentration in the silicon feedstock also depends on the specific procedure used in crystal growth. An example is replenishment growth in the Czochralski method where the tolerable impurity concentration for a given impurity species depends on the number of replenishments and on the fraction of the melt grown between replenishments. Therefore, acceptable impurity levels in silicon can be defined only for a specific process or type of process. In some processes, as in the edge-defined film growth method, there is no redistribution of impurities in the feedstock, and the average impurity concentration in the solar cell is essentially as that in the silicon feedstock.

Section VI includes graphs that can be used to calculate the tolerable impurity concentration for a specific process. A slide rule which facilitates the determination of tolerable impurity concentration as a function of the degradation in solar-cell performance has been developed, and is described in Section VII. A sample calculation (see Figure 7-2) is shown for the tolerable concentration of iron in the silicon feedstock for a $10 \%$ degradation in cell performance using a process where no redistribution of impurities occurs during the process, as in the edge-defined film growth method; it gives a value of $7 \times 10^{-3}$ ppma. A calculation for iron for the Czochralski process (see Figure 7-4) is shown using five replenishments and growing $90 \%$ of the melt between replenishments. For a $10 \%$ degradation in cell performance, a value of about 25 ppma is obtained.

Boron and phosphorus are treated separately because their segregation coefficients are close to unity (i.e., 0.8 and 0.35 , respectively), and because their effects are primarily to alter the resistivity. The upper limit of the tolerable boron concentration in silicon is determined by the lowest resistivity silicon that can be used in the manufacture of solar cells. The low, nominal resistivity for solar cells with present technology is about $0.3+1 \mathrm{ohm}-\mathrm{cm}$, which sets an upper limit to the tolerable boron concentration in silicon feedstock to about 2 ppma. The presence of phosphorus as an 
impurity along with boron leads to compensated material. Compensated material limits the yield of usable crystal because of the rise in resistivity of the grown ingot due to the difference in the segregation coefficients of boron and phosphorus. A greater degree of compensation is tolerable for low-resistivity silicon. For $0.3 \mathrm{ohm}-\mathrm{cm}$ silicon and for five replenishments, using the Czochralski method, the tolerable phosphorus impurity concentration is about 0.5 ppma for a yield of $90 \%$ of usable silicon crystal.

When the total impurity concentration in the melt from which silicon is grown exceeds a critical.value, the crystal structure breaks down. The critical value is largely species-independent, but is a function of the diameter of: the crystal grown and the rate at which it is grown. For crystais of $10 \mathrm{~cm}$ in diameter pulled by the Czochralski method at a rate of about $8 \mathrm{~cm} / \mathrm{h}$, the critical impurity concentration is in the range of 200 to 500 ppma and for five replenishments about a factor of 5 less. In general, it is the electrical characteristics that determine the tolerable concentration of impurities in solar-grade silicon rather than crystal growth effects. If, however, larger crystals and higher growth rates are used, limitations on crystal growth may become a facçor. 
In the development of processes for the production of silicon solar cells to generate electrical power, a number of factors must be considered to arrive. at a cost-effective system. An important factor is the solar-cell efficiency required for this system. The presumption is made that, if requirements on cell efficiency are relaxed, the cost of each cell is reduced:- Cell efficiency is largely determined by the concentration of impurities in the silicon feedstock used. Thus, it is important to investigate the effects of impurities on the performance of the solar cells and try to relate this to the tolerable impurity content in the silicon feedstock used. This report addresses these effects and gives a preliminary definition of solar-grade silicon. The definition is based on the work done by the Westinghouse Research and Development (R\&D) Center and Hemlock Semiconductor under contract to JPL, within the Materials Task of the U.S. Department of Energy (DOE) Low-Cost Solar Array Project (References 1-3). Supporting work was done by C. T: Sah Associates (References 4-7), Northrop Research and Technology Center (Reference 8), Monsanto (Reference 9), Spectrolab (Reference 10) and Solarex (Reference 11).

- Three major factors must be considered to determine the tolerable impurity content in the silicon feedstock: (1) the effect of impurities on the diffusion length of minority carriers and, thus, on the efficiency of the solar cell; (2) the effects of boron impurity on the resistivity and of phosphorus compensation on the yield of usable silicon; and (3) the total concentration of impurities in the silicon feedstock above which structural breakdown of crystal growth occurs.

This report includes a sumnary of the investigation. The summary is followed by an abbreviated derivation of a model consistent with the experimental data. The results of the model are then applied to the selection of suitable silicon in terms of the allowable degradation in solar-cell performance. This definition is followed by the effects of boron and phosphorus contamination and, finally, the effect of the total concentration of impurities in silicon feedstock on crystal growth. 


\section{A. IMPURITY SELECTION}

Impurities were selected primarily from those which commonly occur in metallurgical-grade silicon, a feedstock material for many low-cost silicon processes. Data for a representative example of these impurities are given in Table 2-1. The impurity matrix used in these studies is given in Table 2-2. This matrix includes impurity elements that could be introduced by materials of construction and chemical reactants used in silicon production and in sheet and device fabrication.

\section{B. INGOT PREPARATION}

Czochralski growth was the main method of crystal production; a 1 imited number of float-zone ingots, and single-crystal ribbons produced by the dendritic web method were also studied. An NRC-2805 and a Hamco CG-800

Table 2-1. Typical Impurity Concentrations in Metallurgical Silicona

Al

B

C

Cr

$\mathrm{Cu}$

$\mathrm{Fe}$

Mn

$\mathrm{Ni}$

P

$\mathrm{Ti}$

$\mathrm{V}$

$\mathrm{Zr}$
1300

11

250

390

60

4200

120

100

10

500

230

30

${ }^{a}$ See Reference 2. 
Table 2-2. Impurity Matrix

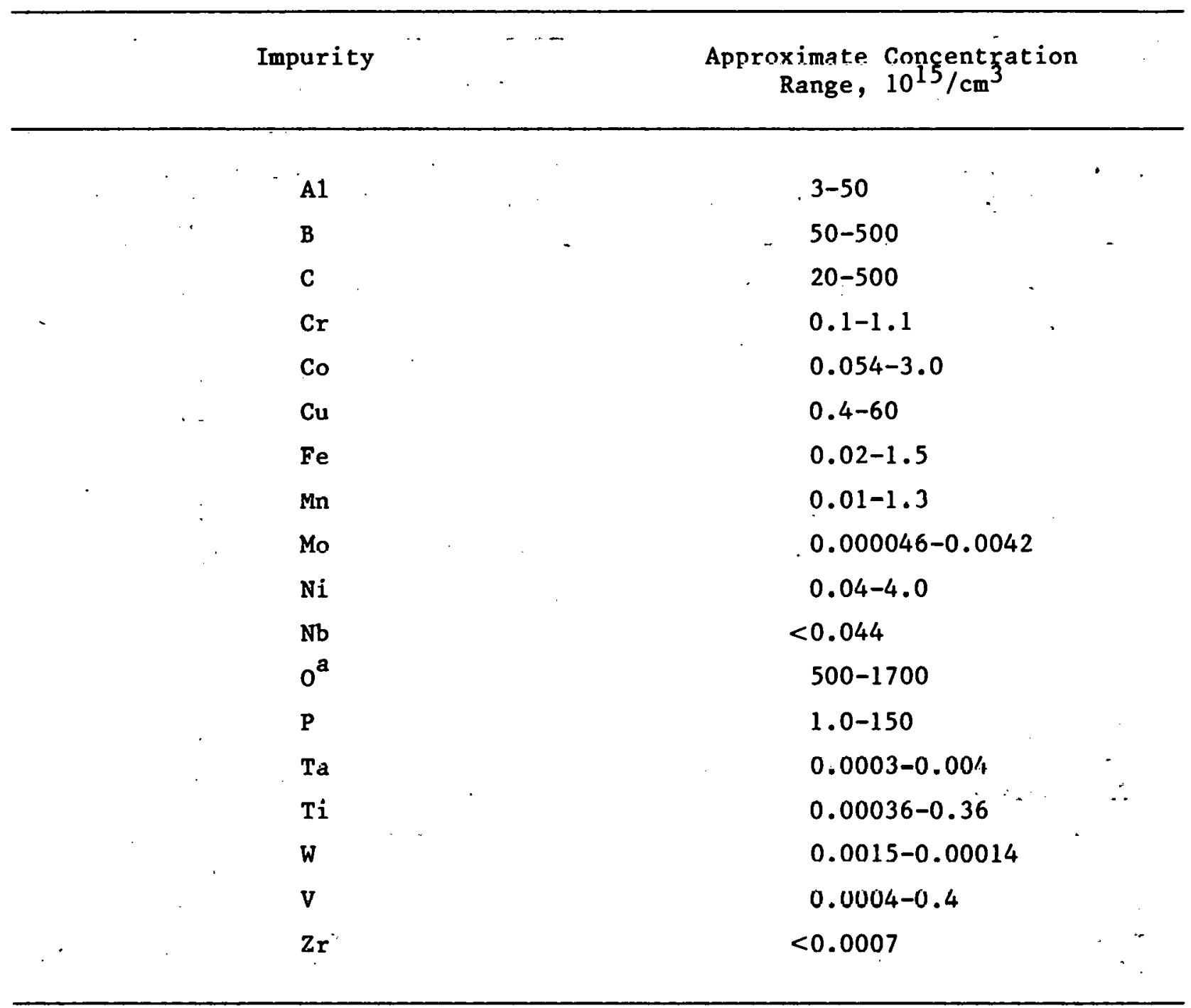

a Oxygen and carbon concentrations measured in approximately 50 ingots doped with additional impurities. Two carbon-doped ingots prepared to determine effects of carbon.

crystal growth furnaces were used during the program. A new quartz crucible was used for each ingot. Before loading the crucible into the furnace, the graphite heating element and graphite furnace parts were baked out for a period of $4 \mathrm{~h}$ at $1500^{\circ} \mathrm{C}$. Vacuum bakeout was employed with the NRC furnace; an argon ambient was used with the HAMCO CG-800. Semiconductor-grade silicon nuggets (Hemlock Semiconductor Corporation) or one-piece crucible charges were used throughout this entire program. Typical characteristics of this material are given in Table 2-3. The impurities in the polycrystalline silicon are so low in concentration that their presence does not affect solar-cell performance. Numerous undoped baseline audit ingots were prepared to evaluate the 
Table 2-3. Polycrystalline Silicon Analysis

\begin{tabular}{|c|c|c|c|}
\hline \multirow{2}{*}{$\begin{array}{l}\text { Crystal Method } \\
\text { Impurity }\end{array}$} & \multicolumn{3}{|c|}{ Analytical Method } \\
\hline & $\begin{array}{l}\mathrm{NAA}^{\mathrm{a}} \\
\mathrm{ppba}\end{array}$ & $\begin{array}{l}\text { SSMS }^{b} \\
\text { ppba }^{b}\end{array}$ & $\begin{array}{c}\text { SSMS } / \text { Freeze-Out } \\
\text { ppba }\end{array}$ \\
\hline \multirow{2}{*}{$\begin{array}{l}\mathrm{Cr} \\
\mathrm{Cu}\end{array}$} & $<4 \times 10^{-2}$ & $<3$ & 20.01 \\
\hline & $6 \times 10^{-3}$ & $<20$ & 20.01 \\
\hline $\mathrm{Fe}$ & $<2$ & $<30$ & 20.1 \\
\hline $\mathrm{Mn}$ & $<1.5$ & $<3$ & 20.01 \\
\hline $\mathrm{Ni}$ & $<0.2$ & $<30$ & ND \\
\hline $\mathrm{Ti}$ & $<4$ & $<5$ & ND \\
\hline 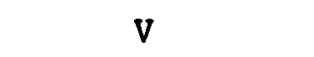 & -- & $<3$ & ND \\
\hline $\mathrm{Zn}$ & - & $<5$ & ND \\
\hline $\mathrm{Zr}$ & -- & $<12$ & ND \\
\hline \multicolumn{4}{|c|}{$\begin{array}{l}\text { a Neutron Activation Analysis. } \\
\text { b Spark Source Mass Spectroscopy. } \\
{ }^{c} \text { SSMS analysis of impurities concentrated by float zoning. }\end{array}$} \\
\hline
\end{tabular}

charge material and potential contamination from the growth furnaces. No degradation has been observed in the cell performance of devices made from these ingots.

The form and purity of each metal used to dope the silicon ingots and web crystals are 1 isted in Table 2-4. Where possible, four nines purity (or better) grades of metal were chosen, $\mathrm{V}, \mathrm{Ni}$ and Mo are notable exceptions. Worst-case trace impurities were expected to be no greater than $1 / 1000$ the concentration of the primary metal dopant.

Czochralski crystal growth conditions were:

(1) Pull-speed ranged between 7 and $8.5 \mathrm{~cm} / \mathrm{h}$.

(2) Crystal rotation rate was about $10 \mathrm{rpm}$.

(3) Most ingots were $3 \mathrm{~cm}$ in diameter.

(4) A11 crystals were oriented along $\langle 111\rangle$ and grown in argon atmosphere. 
Table 2-4. Characteristics of Dopant Materials

\begin{tabular}{lcl}
\hline Impurity & Purity, \% & \multicolumn{1}{c}{ Form } \\
\hline Al & 99.99 & Wire \\
B & $>99.9999$ & Doped silicon rod \\
C & 99.999 & Graphite rod \\
Cr & 99.999 & Pellets \\
Co & 99.99 & Polyrgystal rod \\
Cu & 99.9997 & Zult refiuled iuguls \\
Fe & 99.999 & Spunge \\
Mn & 99.99 & Flake \\
Mo & 99.98 & Pellets \\
Ni & 99.98 & Sponge wire \\
Nb & 99.99 & Polycrystal rod \\
P & $>99.9999$ & Doped silicon rod \\
Ta & 99.99 & Polycrystal rod \\
Ti & 99.95 & Crystal \\
W & 99.999 & Polycrystal rod \\
Va & 99.9 & Detudrile \\
Zr & 99.99 & Foil \\
\hline
\end{tabular}

\section{INGOT CHARACTERIZATION}

About 200 ingots were produced and characterized. The target resistivities were achieved without difficulty, and the etch-pit densities were typically less than $10^{3} / \mathrm{cm}^{2}$ on materials used to produce solar cells. About $30 \%$ of the ingots had zero dislocation densities, although no special effort was made to achieve this result. Carbon and oxygen concentrations were measured on alternate ingots by infrared (IR) absorption spectroscopy, and the values were in the ranges $2 \times 10^{16}$ to $5 \times 10^{17} / \mathrm{cm}^{3}$ and $5 \times 10^{17}$ to $1.5 \times 10^{18} / \mathrm{cm}^{3}$, respectively. These values are common to Czochralski silicon.

Some complementary analytical methods were employed to characterize the crystal quality, chemistry, and electrical properties of the as-grown ingots. The sampling procedure is shown in Figure 2-1. Specimens for etch-pit density, IR transmission, spark source mass spectroscopy (SSMS), and neutron activation analysis (NAA) were taken primarily from region (1), although some analyses 


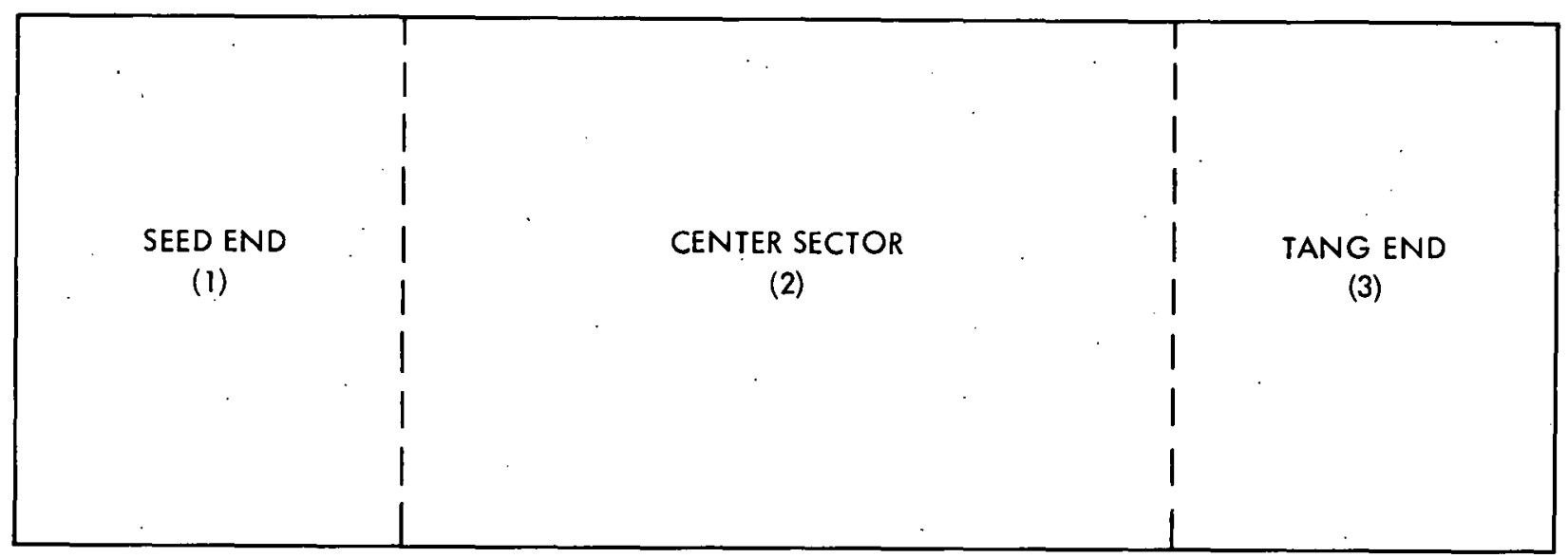

(1) $3 \mathrm{~cm}$ SEED ANALYTICAL MATERIAL (IR, SSMS, NAA, ETCHING)

(2) $12.5 \mathrm{~cm}$ SOLAR CELL BLANK MATERIAL

(3) $3 \mathrm{~cm}$ TANG ANALYTICAL MATERIAL (SSMS, NAA, ETCHING)

INGOT $=0.3-0.6 \mathrm{~kg}(3 \mathrm{~cm} \mathrm{DIA}), 2.8-3.3 \mathrm{~kg}(7.6 \mathrm{~cm} \mathrm{DIA})$

CHARGE $=0.85-1.5 \mathrm{~kg}(3 \mathrm{~cm}$ DIA $), 2.8-3.3 \mathrm{~kg}(7.6 \mathrm{~cm}$ DIA $)$

Figure 2-1. Silicon Ingot Sampling

were also performed on material from region (3). All wafers came from region (2). The ingot weight used through the seed-end analytical material and solar-cell blank slices was limited to no more than $25 \%$ of melt weight. This assured small variations of the impurity concentration along the length of material evaluated. NAA analyses of seed- and tang-end samples from several doped ingots indicated that total changes in impurity concentration along the length of the ingot are a maximum of $47 \%$ (i.e., in the case of manganese). Variation within the region devoted to solar-cell blanks was significantly less than this extreme.

The etch-pit density was measured on seed- and tang-end specimens following Sirtl etching, Reference 12. The slices examined were taken, from the extreme ends of regions (1) and (3) as shown in Figure 2-1. The etch-pit density of the solar-cell blanks was most comparable to that of the seed material, typically $10^{3} / \mathrm{cm}^{2}$ or less. Tang-end densities sometimes reached. $10^{5}$ to $10^{6} / \mathrm{cm}^{2}$ dislocations when structural breakdown occurred due to impurities. As much as $30 \%$ of the ingots were dislocation-free, although no special effort was taken to achieve this result. 
SECTION III

IMPURITY ANALYSIS

\section{A. INGOT IMPURITY CONCENTRATIONS}

To derive a quantitative relationship between solar-cell performance and ingot impurity content, a reasonably accurate determination of the metal concentrations is required for each test ingot. The maximum melt concentration attainable for most elements studied was in the range of $1 \times 10^{20} \mathrm{a} / \mathrm{cm}^{3}$ to $4 \times 10^{20} \mathrm{a} / \mathrm{cm}^{3}$. Higher melt concentrations resulted in polycrystalline ingot growth. This concentration range coupled with the extremely small effective segregation coefficients for many of the impurities results in ingot concentrations ranging from less than $10^{12} \mathrm{a} / \mathrm{cm}^{3}$ to values only as high as $1 \times 10^{16} \mathrm{a} / \mathrm{cm}^{3}$. This corresponds to required detection limits of from 0.02 to 200 parts per billion atomic (ppba). The accurate determination of impurity concentrations was one of the most difficult parts of this program.

The only methods generally applicable to these ranges are SSMS and NAA. Typical detection limits for these methods are given in Table 3-1 (see References 10 and 11). Samples from al1 ingots were analyzed by SSMS, and selected samples were subjected to NAA. (NAA was performed at General Activation Analysis, San Diego, California, and Kraftwerke Union A. G., Erlangen, West Germany.) For each ingot a vacuum cast melt sample analyzed by atomic absorption or emission spectroscopy completed the analytical data. By taking the ratio of the ingot impurity concentration, $C_{S}$, to the liquid impurity concentration, $C$, the effective segregation coefficient, ( $k_{e f f}$ ), was derived for each impurity. Segregation coefficients determined for the most heavily doped ingots were used to calculate the ingot impurity concentration in cases where the ingot impurity level fell below the detection limits of all the analytical methods. $\mathrm{Zr}$ and $\mathrm{Nb}$ have yet to be detected in a single crystal ingot. Thus, $\mathrm{Zr}$ and $\mathrm{Nb}$ concentrations represented upper 1 imits. The segregation coefficients obtained in this way are given in Table 3-2.

\section{B. UNINTENTIONALLY ADDED IMPURITIES}

In addition to direct analysis of the added metal concentration, an effort was made to ensure that unintentionally added impurities were not present in doped and undoped ingots. The sensitivity of the SSMS measurements is inadequate to detect the majority of potential contaminants below the concentration of about $1.5 \times 10^{14} \mathrm{a} / \mathrm{cm}^{3}$; therefore, NAA was used to examine 26 selected samples. A typical analysis is shown in Table 3-3; these concentrations are below those belleved to have an impact on solar-cell performance. 
Table 3-1. Typical Detection Limits of Analytical Techniques Employed in this Investigation ${ }^{a}$

\begin{tabular}{|c|c|c|c|c|}
\hline \multirow[b]{2}{*}{ Impurity } & \multicolumn{4}{|c|}{ Analytical Method } \\
\hline & $\begin{array}{c}\text { Resistivity } \\
\text { ppba }\end{array}$ & $\begin{array}{c}\text { Infrared, } \\
\text { ppba }\end{array}$ & $\begin{array}{l}\text { SSMS, } \\
\text { ppba }\end{array}$ & $\mathrm{NAA}^{\mathrm{b}}, \mathrm{ppba}$ \\
\hline A1 & 4 & & 50 & --- \\
\hline $\mathbf{B}$ & $<1$ & & & --- \\
\hline $\mathrm{C}$ & & $3.5 \times 10^{-2}$ & 500 & $\ldots$ \\
\hline $\mathrm{Cr}$ & & & 3 & $0.04 / 5$ \\
\hline Co & & & 50 & $0.006 / 31$ \\
\hline $\mathrm{Cu}$ & & & 15 & $0.006 / 3$ \\
\hline $\mathrm{Fe}$ & - & & 30 & $21 / 20 \times 10^{3}$ \\
\hline$M n$ & & & 3 & $0.002 / 2$ \\
\hline Mo & & & 10 & $0.01 / 5$ \\
\hline $\mathrm{Ni}$ & & & 30 & $0.2 / 8 \times 10^{3}$ \\
\hline $\mathrm{Nb}$ & & & 3 & --- \\
\hline 0 & & 1.100 & & --- \\
\hline $\mathrm{T} \mathbf{a}$ & & & 10 & $0.001 / 5$ \\
\hline $\mathbf{T i}$ & & & 5 & $0.5 /-$ \\
\hline $\mathbf{w}$ & & & 3 & $\quad 0.0001 / 13$ \\
\hline $\mathrm{Va}$ & & & 3 & $220 /-$ \\
\hline $\mathbf{Z r}$ & & & $12-15$ & $0.5 / 200$ \\
\hline
\end{tabular}

asee References 13 and 14 .

$\mathrm{b}_{\text {Kraftwerke Union data/General Atomic data. }}$ 
Table 3-2. Segregation Coefficients

\begin{tabular}{lc}
\hline Element & Segregation Coefficient \\
\hline Al & $3 \times 10^{-2}$ \\
B & 0.8 \\
Co & $2 \times 10^{-5}$ \\
Cr & $1.1 \times 10^{-5}$ \\
Fe & $6.4 \times 10^{-6}$ \\
Mn & $1.3 \times 10^{-5}$ \\
Mo & $4.5 \times 10^{-8}$ \\
Ni & $1.3 \times 10^{-4}$ \\
Nb & $<4.4 \times 10^{-7}$ \\
P & 0.35 \\
Ta & $2.1 \times 10^{-8}$ \\
Ti & $2 \times 10^{-6}$ \\
V & $4 \times 10^{-6}$ \\
W & $1.7 \times 10^{-8}$ \\
Zr & $<1.6 \times 10^{-8}$ \\
& 210 \\
\hline
\end{tabular}


Table 3-3. Neutron Activation Analysis for Impurities Not Intentionally Added

\section{Concentration}

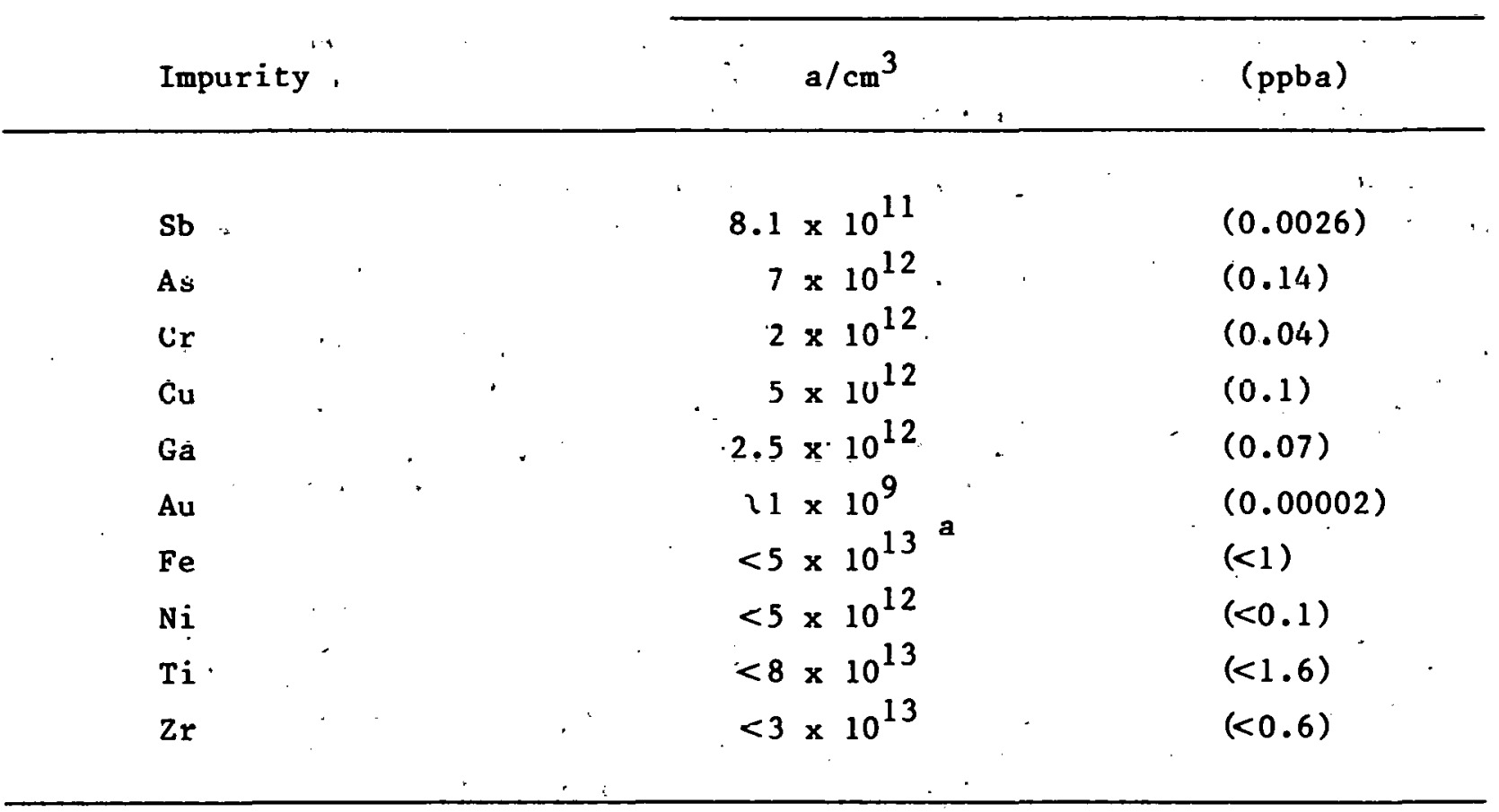

${ }^{a}$ Iron was detected at concentrations of $i \times 10^{14}$ to $1.7 \times 10^{14} \mathrm{a} / \mathrm{cm}^{3}$ in ingots heavily doped with nickel. 
SECTION IV

ELECTRICAL CHARACTERIZATION OF MATERIAL

\section{A. ELECTRICAL MEASUREMENTS}

A brief description of the electrical measurements made on wafers from impurity-doped ingots, the process used to fabricate solar cells, and the measurements made on solar cells is presented here.

Deep-Level Transient Spectroscopy (DLTS) measurements were made on wafers before and after processing into solar cells to characterize carrier recombination centers introduced by impurities and to investigate the effects of processing and gettering on recombination centers. These recombination centers, which are introduced by impurities, determine the minority carrier lifetime and diffusion length in silicon and, thus, the performance of solar cells. The energy levels, density, and capture rates of these centers were determined. Measurements were also made by C. T. Sah Associates on selected samples using the Thermally Stimulated Capacitance (TSCAP) method (see Reference 4).

As part of these studies, recombination 1 ifetime measurements were made on wafers before and after processing into solar cells by the photoconductive decay and the open-circuit decay methods. Lifetime and diffusion length measurements were also made by Northrop Research Center (see Reference 7) on solar-cell blanks and solar cells under a supporting contract from JPL. The results are in substantial agreement with the results obtained by the Westinghouse R\&D Center (see Reference 1, Vol. 1, Table 16).

\section{B. TEST SOLAR CELLS}

Test solar cells were fabricated from the impurity-doped ingots, and their performance characteristics were compared with baseline cells. The basic design of these cells consisted of $3000 \AA, 60 \mathrm{ohm} / \mathrm{sq}$ phosphorus diffusion into a $250 \mu \mathrm{m}$ thick, 2 to $4 \mathrm{ohm}-\mathrm{cm} \mathrm{p}$-type (boron doped) wafer. The active area was defined by a mesa etch 5 co $8 \mu \mathrm{m}$ deep and the active area was $1 \mathrm{~cm}^{2}$. The precleaned wafers were phosphorus diffused at $850^{\circ} \mathrm{C}$ for 50 min resulting in a junction depth of $0.35 \mu \mathrm{m}$. The front contact grid was a titanium-palladium-silver ( $\mathrm{Ti}-\mathrm{Pd}-\mathrm{Ag})$ metallization that was sintered at $550^{\circ} \mathrm{C}$ for $15 \mathrm{~min}$ in hydrogen. The average efficiency of baseline cells (no added impurities) was about $10 \%$ without anti-reflection (AR) coating. The average efficiency with coatings was $14.1 \%$. The usual experimental run consisted of 15 to 25 wafers from the metal-doped ingots along with 5 to 8 uncontaminated base wafers. Cell characterizations are given in Reference 1, Table 16. 
C. SOLAR CELLS USING STANDARD COMMERCIAL PROCESS

Solar cells were also fabricated and characterized by standard commercial processes using wafers from the Westinghouse impurity-doped ingots (see References 10 and 11 ). About 15 wafers from each impurity-doped ingot were fabricated into solar cells with baseline wafers. Standard AR coatings were applied: the cells were characterized by measurements of short-circuit current, open-circuit voltage, efficiency, fill factor and spectral response. These results were in substantial agreement with those obtained by the Westinghouse R\&D Center and are available in reports of the referenced contracts. 
SECTION $V$

SOLAR-CELL MODEL

\section{A. MODEL APPROACH AND ASSUMPTIONS}

The data obtained on the solar cells used in these studies (i.e., > 10,000 devices) have been correlated by an empirical model developed by the Westinghouse R\&D Center (see Reference 1). This model is one of the major bases on which solar-grade silicon can be defined. A review of the assumptions and an abbreviated derivation of this model are given in the following paragraphs. A more complete account is given in Reference 1.

The model assumes that the effective base diffusion length, $L_{n}$, characterizes the impurity effects. However, the diffusion length, or equivalently the minority carrier lifetime, is a difficult and time-consuming parameter to measure accurately.

Thus, the model uses the short circuit current, $I_{s c}$, of the solar cells fabricated from impurity containing silicon as the major indicator of the effects of impurities and then relates the short-circuit current to $L_{n}$. In addition, the solar spectrum is represented by an equivalent monochromatic illumination to obtain a solution in analytical form. The performance of impurity-doped cells is compared with that of baseline cells; the resultant efficiencies of the doped cells are given in normalized form relative to baseline cells.

\section{B. DERIVATION OF MODEL}

1. Relation Between Short-Circuit Current and Diffusion Length

The differential equation relating the diffusion length with the photo current for a single wavelength is:

$$
\mathrm{dI}_{\lambda}=\mathrm{qA}\left(\mathrm{N}_{\lambda} / \mathrm{L}_{\lambda}\right)\left(1-\mathrm{R}_{\lambda}\right) \cdot \exp \left[-\mathrm{x}\left(1 / \mathrm{L}_{\lambda}+1 / \mathrm{L}_{\mathrm{n}}\right)\right] \mathrm{dx}
$$

where it is assumed that the base width is large compared to the diffusion length, $L_{n}$, and the absorption length, $L_{\lambda}$, and:

$q=$ electronic charge

$\mathrm{A}=\mathrm{ce} 11$ area, $\mathrm{cm}^{2}$

$\mathrm{N}_{\lambda}=$ incident photons at wavelength $\lambda ; \mathrm{s}^{-1} / \mathrm{cm}^{2}$

$\mathrm{R}_{\lambda}=$ reflection coefficient at wavelength $\lambda$

$\mathrm{I}_{\lambda}=$ photocurrent for illumination with wavelength $\lambda$

The solution at a given wavelength is:

$$
I_{\lambda}=\frac{q A\left(N_{\lambda} / L_{\lambda}\right)\left(1-R_{\lambda}\right)}{\left[\frac{1}{L}+\frac{1}{L_{n}}\right]} \cdot 1-\exp \left[-x\left(1 / L_{\lambda}+1 / L_{n}\right)\right]
$$


For a wavelength near the middle of the solar spectrum, the absorption length $\mathrm{L}_{\lambda}$ is about $20 \mu \mathrm{m}$. Thus, for a nominal effective base thickness, the exponential term is approximately unity so that defining new variables:

$$
\begin{aligned}
I_{s c o} & =I_{s c}(\text { baseline sample) } \\
I_{n} & =\frac{I_{s c}(\text { impurity sample) }}{I_{\text {sco }}} \\
I_{n \infty} & =I_{s c}\left(L_{n}=\infty\right)=\frac{\mathrm{qAN}_{\lambda}\left(1-R_{\lambda}\right)}{I_{s c o}}
\end{aligned}
$$

and

$$
I_{n}=I_{n \infty} \frac{1}{L_{\lambda} / L_{n}+1}
$$

A least-squares fit of Equation (3) to experimental data given in Reference 1 is shown in Figure $5-1$. This provides the values $I_{n_{m}}=1.11$ and $L_{\lambda}=19.2 \mu \mathrm{m}$ which correspond to a wavelength of $869 \mathrm{~nm}$ which is in the mid-range of the solar spectrum. $I_{n \infty}$ and $L_{\lambda}$ are model constants. The diffusion length within the cells depends on the density of recombination centers. It is assumed that there are no concentration-dependent effects and so the density of centers, $\mathrm{N}_{\mathrm{T}}$, is proportional to the total concentration of metal impurity atoms, $\mathrm{N}_{\mathbf{x}} \cdot \mathrm{N}_{\mathrm{T}}$ need not equal $\mathrm{N}_{\mathbf{x}}$, as many metal atoms are only partially active as recombination centers. Figure 5-2 illustrates this point for $\mathrm{Cr}, \mathrm{V}, \mathrm{Ti}$ and $\mathrm{Mo}$.

The lifetime, $\tau$, as a junction of $\mathrm{N}_{\mathrm{T}}$ under low-level injection, can be approximated by:

$$
\tau=\frac{1}{\beta_{\mathrm{X}} \mathrm{N}_{\mathrm{T}}}
$$

where $\beta_{X}$, the capture rate of carriers due to recombination centers introduced by impurities $x$, and $\mathrm{N}_{T}$, are both measured by deep-level spectroscopy methods. Equation (4) can be expressed in terms of $N_{x}$ as:

$$
\tau=\frac{1}{\beta_{x^{2} x^{N} T}}
$$

where $a_{x}$ is a proportionality factor giving the fraction of impurities that introduce recombination centers. With several independent lifetimes, the effective lifetime is obtained by Mathiessen's rule as:

$$
\frac{1}{\tau}=\frac{1}{\tau_{0}}+\frac{1}{\tau_{x}}+\cdots \frac{1}{\tau_{z}}
$$

where $\tau_{0}$ is the lifetime observed in uncontaminated baseline samples and $\tau_{x} \ldots \tau_{z}$ are lifetimes associated with metals $x \ldots z$. 


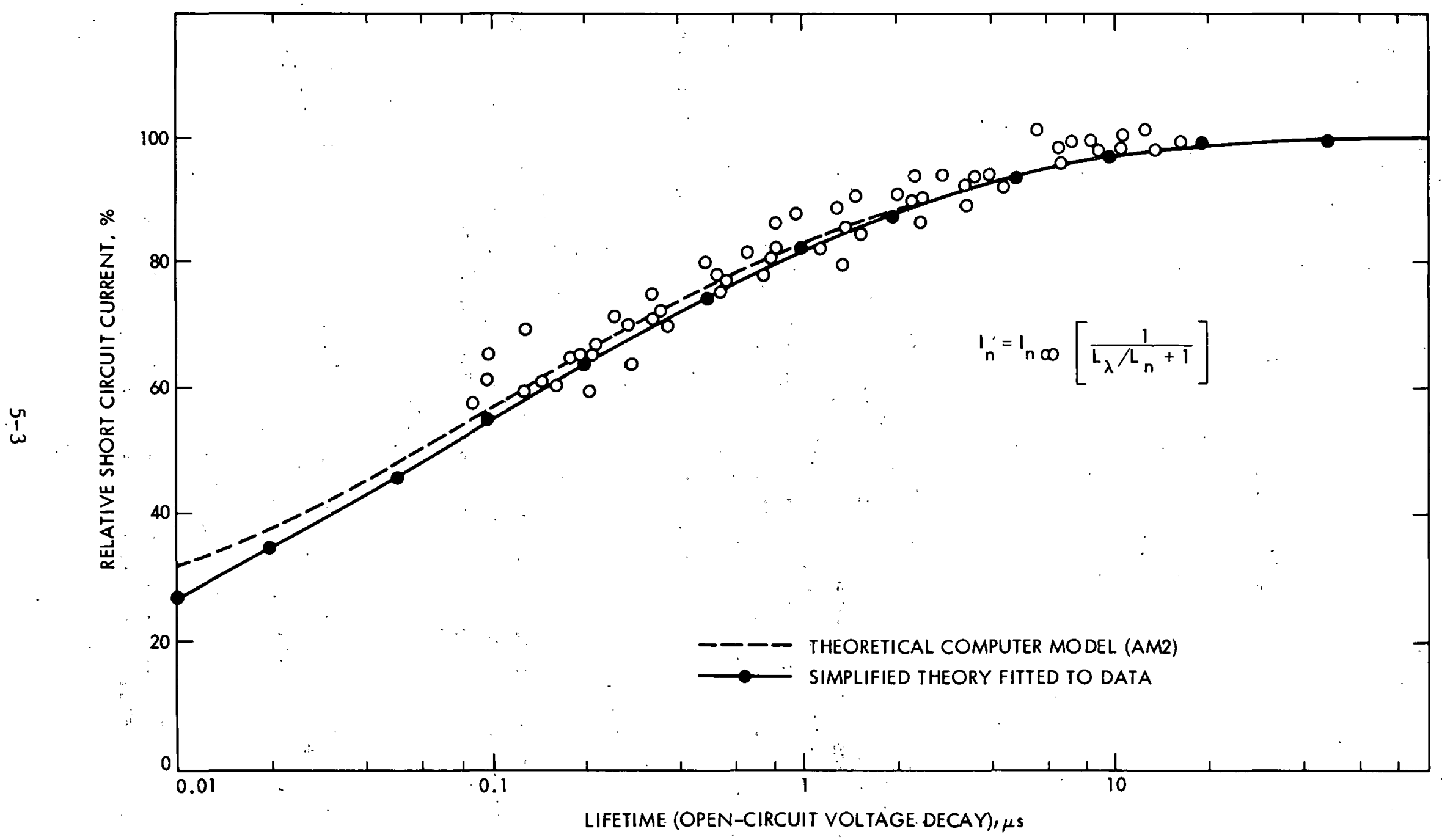

Figure 5-1. Minority Carrier Lifetime versus Relative Short-Circuit Current 


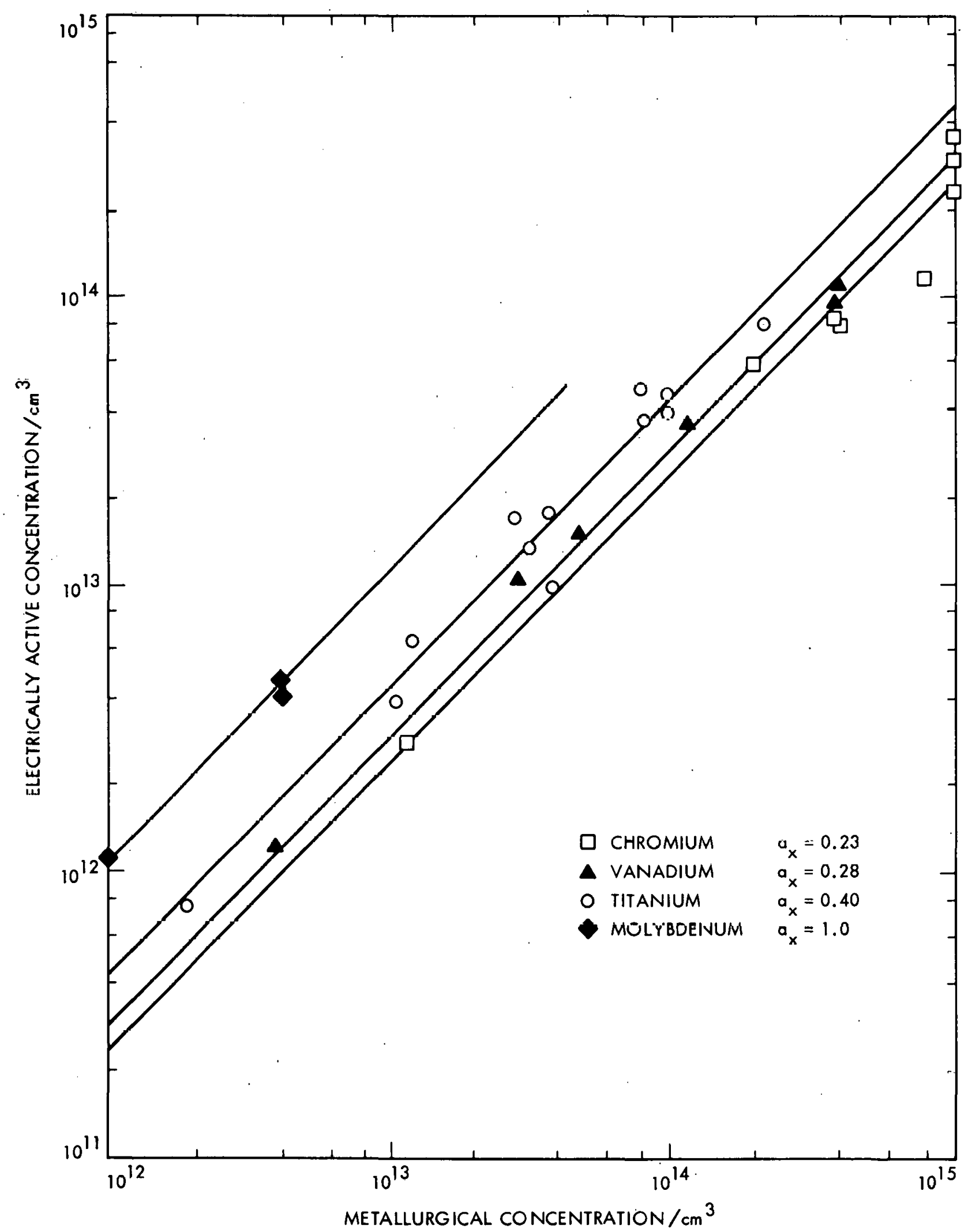

Figure 5-2. Variation in Electrically Active Impurity Concentration as a Function of the Metallurgically Added Impurity Content of As-Grown Ingots 
Equation (6) can be expressed in terms of the diffusion length, $L_{n}$, via the Einstein relation

$$
\mathrm{L}_{\mathrm{n}}^{2}=\mathrm{Dn} \tau
$$

as

$$
\frac{1}{L_{n}^{2}}=\frac{1}{L_{n}^{2}}+k_{x} N_{x}+\ldots+k_{z} N_{z}
$$

where

$$
k_{x}=\frac{\beta_{x} a_{x}}{D_{n}}
$$

Equation (7) can then be expressed as:

$$
\left(\frac{I_{n}}{I_{n}-1}\right)^{2}=L_{\lambda}^{2}\left[1 / L_{n o}^{2}+k_{x} N_{x}+\ldots k_{z} N_{z}\right]
$$

For samples containing single metal impurities, Equation ( 8 ) becomes

$$
\left(\frac{I_{n \infty}}{I_{n}}-1\right)^{2}=C_{1 x}+C_{2 x} N_{x}
$$

where $c_{1 x}$ and $c_{2 x}$ are defined as $L_{\lambda}^{2} / L_{\text {no }}^{2}$ and $L^{2} k_{x}$, respectively.

By defining $\mathrm{N}_{\text {ox }}=\mathrm{C}_{1 \mathrm{x}} / \mathrm{C}_{2 \mathrm{x}}$, we have

$$
\left(\frac{I_{n \infty}}{I_{n}}-1\right)^{2}=C_{1 x}\left(1+\frac{N_{x}}{N_{o x}}\right)
$$

Model constants $\mathrm{C}_{1 \mathrm{x}}, \mathrm{C}_{2 \mathrm{x}}$, and $\mathrm{N}_{\mathrm{ox}}$ were obtained by a least-squares fit to experimental data (see Reference 1, Table 16) for solar cells doped with impurities and are given in Tables 5-1 and 5-2 for p- and n-base material, respectively.

\section{Open-Circuit Voltage in Terms of the Short-Circuit Current}

The normalized open-circuit voltage is expressed in terms of the normalized short-circuit current in the following way. In the diffusion controlled model the normalized open-circuit voltage, $v_{n}$, can be expressed as shown in Equation (11); see Reference 13. 
Table 5-1. Mode1 Coefficients for Singly-Doped, p-Base Solar Cells

\begin{tabular}{llll}
\hline Impurity & \multicolumn{1}{c}{$\mathrm{C}_{1 \mathrm{x}}$} & \multicolumn{1}{c}{$\mathrm{C}_{2 \mathrm{X}}$} \\
\hline $\mathrm{A} 1$ & $1.2 \mathrm{E}-02$ & $2.9 \mathrm{E}-18$ & $4.4 \mathrm{E}+15$ \\
$\mathrm{Cr}$ & $9.2 \mathrm{E}-03$ & $6.7 \mathrm{E}-17$ & $1.3 \mathrm{E}+14$ \\
$\mathrm{Cu}$ & $1.2 \mathrm{E}-02$ & $3.0 \mathrm{E}-20$ & $4.1 \mathrm{E}+17$ \\
$\mathrm{Fe}$ & $1.2 \mathrm{E}-02$ & $4.7 \mathrm{E}-17$ & $2.5 \mathrm{E}+14$ \\
$\mathrm{Mn}$ & $9.8 \mathrm{E}-03$ & $5.3 \mathrm{E}-17$ & $1.8 \mathrm{E}+14$ \\
$\mathrm{Mo}$ & $1.3 \mathrm{E}-02$ & $12.0 \mathrm{E}-14$ & $6.0 \mathrm{~F}+12$ \\
$\mathrm{Ni}$ & $1.4 \mathrm{E}=02$ & $2.5 \mathrm{E}-18$ & $5.0 \mathrm{E}+15$ \\
$\mathrm{P}$ & $1.1 \mathrm{E}-02$ & $6.8 \mathrm{E}-21$ & $1.7 \mathrm{E}+18$ \\
$\mathrm{Ta}$ & $1.2 \mathrm{E}-02$ & $5.1 \mathrm{E}-14$ & $2.3 \mathrm{E}+11$ \\
$\mathrm{Ti}$ & $1.2 \mathrm{E}-02$ & $4.5 \mathrm{E}-15$ & $2.6 \mathrm{E}+12$ \\
$\mathrm{Va}$ & $1.3 \mathrm{E}-02$ & $5.4 \mathrm{E}-15$ & $2.5 \mathrm{E}+12$ \\
$\mathrm{Zr}$ & $1.0 \mathrm{E}-02$ & $2.7 \mathrm{E}-14$ & $3.6 \mathrm{E}+11$ \\
$\mathrm{~W}$ & $1.1 \mathrm{E}-02$ & $9.1 \mathrm{E}-15$ & $1.2 \mathrm{E}+12$ \\
$\mathrm{Co}$ & $1.2 \mathrm{E}-02$ & $1.0 \mathrm{E}-17$ & $1.1 \mathrm{E}+15$ \\
$\mathrm{Nb}$ & $1.2 \mathrm{E}-02$ & $7.4 \mathrm{E}-15$ & $1.6 \mathrm{E}+12$ \\
\hline
\end{tabular}

Table 5-2. Model Coefficients for Singly-Doped, n-Base Solar Cells ${ }^{a}$

\begin{tabular}{cccc}
\hline Impurity & $\mathrm{C}_{1 \mathrm{x}}$ & $\mathrm{C}_{2 \mathrm{x}}$ & $\mathrm{N}_{\mathrm{OX}}$ \\
\hline $\mathrm{Al}$ & $1.0 \mathrm{E}-02$ & $1.1 \mathrm{E}-18$ & $8.5 \mathrm{E}+16$ \\
$\mathrm{Cr}$ & $1.0 \mathrm{E}-02$ & $8.7 \mathrm{E}-17$ & $1.2 \mathrm{E}+14$ \\
$\mathrm{Cu}$ & $1.1 \mathrm{E}-02$ & $1.3 \mathrm{E}-19$ & $8.0 \mathrm{E}+16$ \\
$\mathrm{Fc}$ & $1.0 \mathrm{E}-02$ & $5.7 \mathrm{E}-17$ & $1.8 \mathrm{E}+14$ \\
$\mathrm{Mn}$ & $1.1 \mathrm{E}-02$ & $1.2 \mathrm{E}-17$ & $9.5 \mathrm{E}+14$ \\
$\mathrm{Ti}$ & $1.3 \mathrm{E}-02$ & $3.6 \mathrm{E}-16$ & $3.7 \mathrm{E}+13$ \\
$\mathrm{Va}$ & $1.3 \mathrm{E}-02$ & $3.3 \mathrm{E}-16$ & $4.1 \mathrm{E}+13$ \\
$\mathrm{Mo}$ & $1.1 \mathrm{E}-02$ & $8.5 \mathrm{E}-15$ & $1.3 \mathrm{E}+12$ \\
\hline
\end{tabular}

${ }^{a}$ Data for $\mathrm{Ni}$ do not fit a model based on lifetime reduction as the dominant impurity effect. 


$$
v_{n}=\frac{n V_{T}}{V_{o c o}} \ln \left(\frac{I_{s c}}{I_{o}}\right)
$$

and

$$
I_{0}=\frac{q A n_{i}^{2} D_{n}}{N_{A}^{L} n}
$$

where $n_{i}$ is the intrinsic carrier concentration per $\mathrm{cm}^{3}$, and $D_{n}$ is the minority carrier diffusivity in $\mathrm{cm}^{2} / \mathrm{s}$. Io can be expressed in terms of the normalized short-circuit current by using Equation ( 3 ) as:

$$
I_{0}=\frac{\mathrm{qAn}_{i}^{2} \bar{D}_{n}}{N_{A}} \frac{\bar{I}_{n \infty}}{L}\left(\frac{1}{I_{n}}-\frac{1}{I_{n \infty}}\right)
$$

Combining these equations gives the desired relation between the normalized open-circuit voltage and the normalized short-circuit current. The resulting equation is (see Reference 1, Vol. 2):

$$
v_{n}=E \ln \left(\frac{I_{n}}{\frac{1}{I_{n}}-\frac{1}{I_{n \infty}}}\right)+F
$$

where

$$
\mathrm{E}=\frac{\mathrm{nV}_{\mathrm{T}}}{\mathrm{V}_{\text {oco }}}
$$

and

$$
F=E \ln \left(\frac{N_{A} \dot{L} \dot{I}_{s c o}}{q A n_{i}^{2} D_{n} I_{n \infty}}\right)
$$

A least-squares fit of Equation (14) to experimental data for $4 \mathrm{ohm}-\mathrm{cm}$ p-base devices (see Reference 1) was made and shown in Figure 5-3. The result of the least-squares fit gives $E=0.0472$ and $F=0.8747$ where $N_{A}=3.5 x$ $10^{15} / \mathrm{cm}^{3}, D_{\mathfrak{n}}=32 \mathrm{~cm}^{2} / \mathrm{s}, L_{\lambda}=0.0019 \mathrm{~cm}, I_{s c o}=0.0225 \mathrm{AMP}, A=1 \mathrm{~cm}^{2}$, $\mathrm{v}_{\text {oco }}=0.556 \mathrm{~V}$. $\mathrm{I}_{\mathrm{n} \infty}$ and $\mathrm{L}_{\lambda}$ are deduced from the experimental data and the remaining values are measured.

\section{The Efficiency in Terms of the Short-Circuit Current}

The efficiency is related to the short-circuit current by using the approximate illuminated cell voltage-current Equation (12); see Reference 16.

$$
I=I_{B C}-I_{0} \exp \left(\frac{V}{n V_{T}}\right)
$$




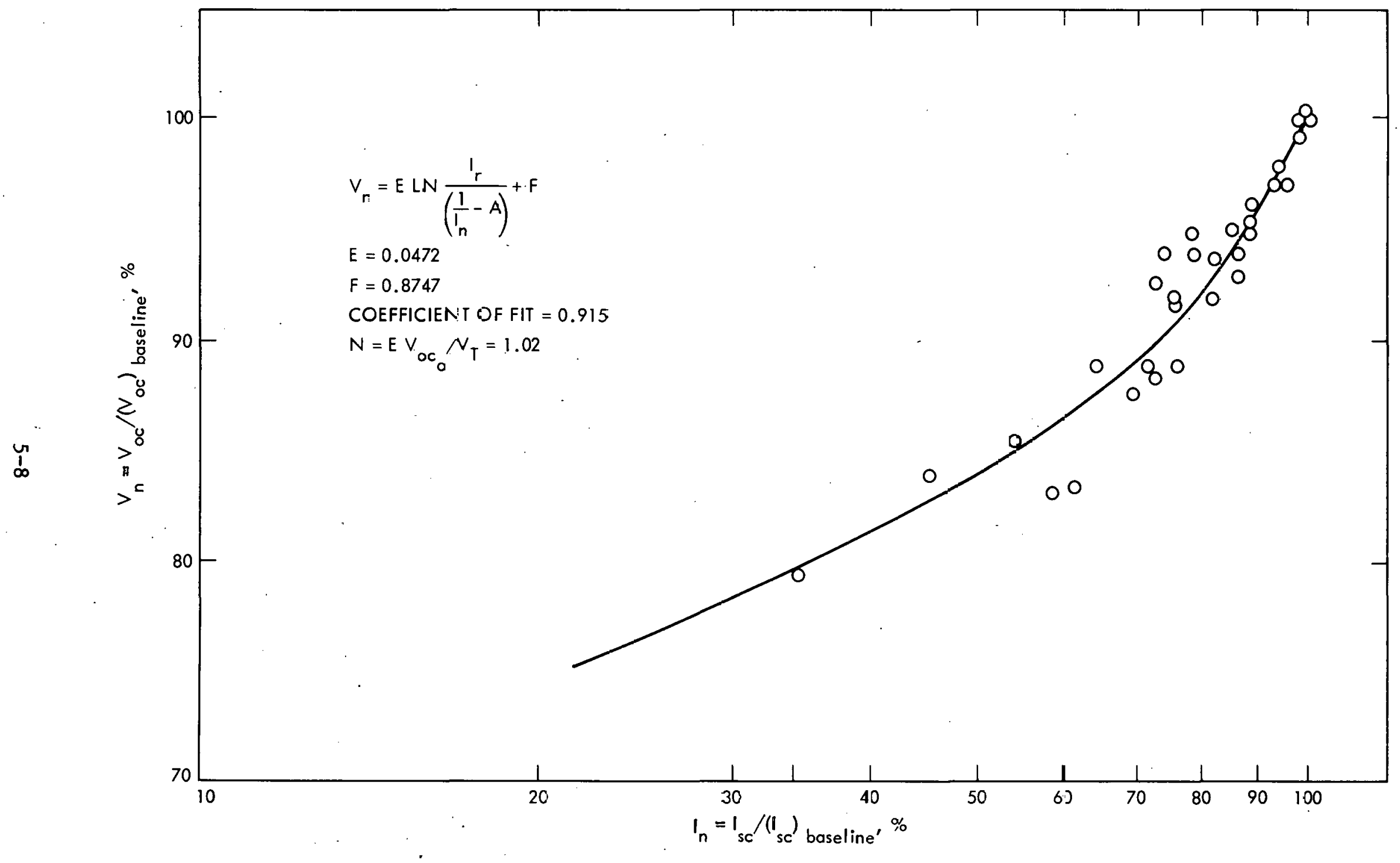

Figure 5-3. Normalized Open-Circuit Voltage as a Function of Norralized Short-Circuit Current for Impurity-Doped Solar Cells Made on 4 ohm-cm Silicon 
By substituting $I_{o}$ in terms of $I_{n}$ by Equation (12) and normalizing the voltage and currents gives

$$
i=I_{n}-G\left(\frac{1}{I_{n}}-\frac{1}{I_{n \infty}}\right) \exp \frac{V_{\text {oco }}}{n V_{T}}
$$

where

$$
G=\frac{q_{A n}^{2} D_{n}^{I} n}{N_{A} I_{\lambda}^{I} \operatorname{sco}}
$$

The normalized peak power is obtained from the cell when

$$
\frac{d p}{d v}=\frac{d(i v)}{d v}=i+v \frac{d i}{d v}=0
$$

thus, substituting Equation (17) for $i$ in Equation (18) we have:

$$
I_{n}-\left[G\left(\frac{1}{I_{n}}-\frac{1}{I_{n \infty}}\right)\right] \exp \frac{v V_{\text {oco }}}{n V_{T}}\left[1+\frac{v V_{\text {oco }}}{n V_{T}}\right]=0
$$

Numerically solving Equation (19) for the peak power voltage, $v_{p}$, and Equation (17), $i_{p}$, with $I_{n}$ as parameter, gives the normalized efficiency, $\eta / \eta_{0}$, where the zero subscripts denote baseline values.

$$
\frac{\eta}{\eta_{0}}=\frac{{ }_{i} v_{p}}{{ }_{p_{0}} v_{0}}
$$

The resulting curves of $\eta / \eta_{0}$ as a function of $I_{n}$ are in good agreement with the experimental data. As Equation (19) has no solution in closed form, an empirical approximation is obtained.

$$
\eta / \eta_{0}=0.872 I_{n}\left(1.128+0.128 I_{n}\right)^{12}
$$

This equation together with a sampling of experimental data is shown in Figure 5-4. 


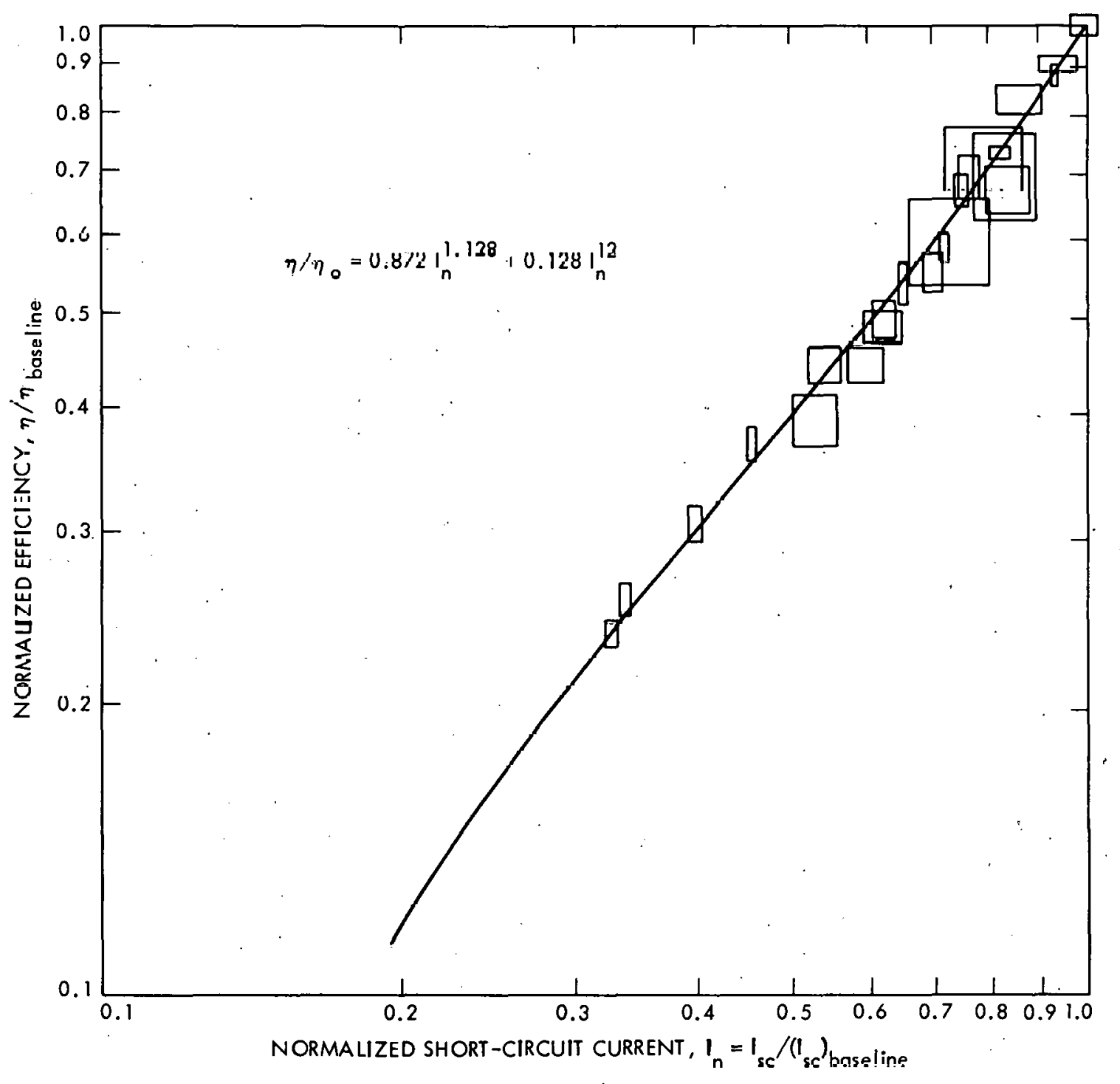

Figure 5-4. Normalized Efficiency as a Function of Normalized Short-Circuit Current 
SECTION VI

EFFICIENCY CONSIDERATIONS FOR SILICON FEEDSTOCK

\section{A. SOLAR-CELL MANUFACTURING PROCESSES FOR WHICH IMPURITY CONCENTRATIONS ARE EQUAL TO THOSE IN FEEDSTOCK}

1. Efficiencies of Solar Cells as a Function of Impurity Concentration for Single Impurities

The efficiencies of solar cells with single impurities, as a function of the impurity concentration, can now be obtained. The procedure is:

Equation (10) with the coefficients $C_{1 x}$ and $N_{o x}$ in Tables 2-1 and 2-2 is first used to obtain $I_{n}$; the normalized efficiency is then obtained from $I_{n}$ using Equation (21). In applying this model, it is convenient to express the impurity concentrations in units of $\mathrm{N}_{\mathrm{Ox}}$ where $\mathrm{x}$ refers to the specific impurity [see Equation (10)]. Values of $\mathrm{N}_{\mathrm{ox}}$ ranging from 0.1 to 100 for the specific impurities are given in Figures $6-1 \mathrm{a}$ and $6-1 \mathrm{~b}$ for p-base material and in Figures $6-2 a$ and $6-2 b$ for $n$-base materials for impurity concentrations expressed in atoms per cubic centimeter $\left(\mathrm{a} / \mathrm{cm}^{3}\right)$ and parts per million atomic (ppma), respectively. An impurity concentration of $\mathrm{N}_{\mathrm{ox}}=0.1$ corresponds very closely to a $1 \%$ degradation in solar-cell performance for all impurities considered. Thus, $0.1 \mathrm{~N}_{\mathrm{ox}}$ can be considered as the threshold impurity concentration beyond which the performance of solar cells containing that impurity degrades. These curves can be used to obtain an overall picture of how the various impurities affect the performance of solar cells. These curves also provide a convenient method of obtaining impurity concentrations for larger degradations in solar-cell performance through the parameter $\mathrm{N}_{\mathrm{Ox}}$. The normalized efficiency $\left(\eta / \eta_{0}\right)$, of solar cells with impurities is now calculated as a function of $\mathrm{N}_{\text {ox }}$; an average curve is given in Figure 6-3 with specific curves given in Appendix A (see Figures A-1 through A-7).

The degradation of solar cells with impurities can be expressed in terms of the normalized efficiency by referring to the proper curve. Although the curves shown in Figures $A-1$ through $A-7$ vary with $C_{1 x}$, the differences are sma11. As stated before, the normalized efficiency is very close to 0.99 for $\mathrm{N}_{\mathrm{ox}}=0.1$, the threshold impurity concentration, for all the impurities. Also, at $\mathrm{N}_{\mathrm{ox}}=0.5$ the normalized efficiency is very close to 0.95 . Thus, for small degradations in cell performance, the relation between $\mathrm{N}_{\mathrm{ox}}$ and the normalized efficiency can be expressed by a single curve. For large values of $\mathrm{N}_{\text {ox }}\left(\mathrm{i} . \mathrm{e}, \mathrm{N}_{\mathrm{ox}}=30\right.$ ), chromium (Figure $\mathrm{A}-2$ ), and nickel (Figure $\mathrm{A}-5$ ), the elements with the extreme values of $\mathrm{C}_{1 \mathrm{x}}$ (i.e., 0.92 and 1.4 , respectively), have degradation factors of 0.60 and 0.56 , respectively, which correspond to a difference of about $7 \%$. Therefore, for approximate calculations, one can assume that $C_{1 x}$ is independent of impurity species, and a single curve can be used to relate the normalized efficiency with $\mathrm{N}_{\text {ox }}{ }^{\circ}$ In Figure $\mathrm{A}-1, \mathrm{C}_{1 \mathrm{x}}$ is 1.2 , and this value is common to seven of the impurities investigated. Therefore, Figure A-1 is applicable to all impurities for approximate calculations and is shown as Figure 6-3 in the text. 


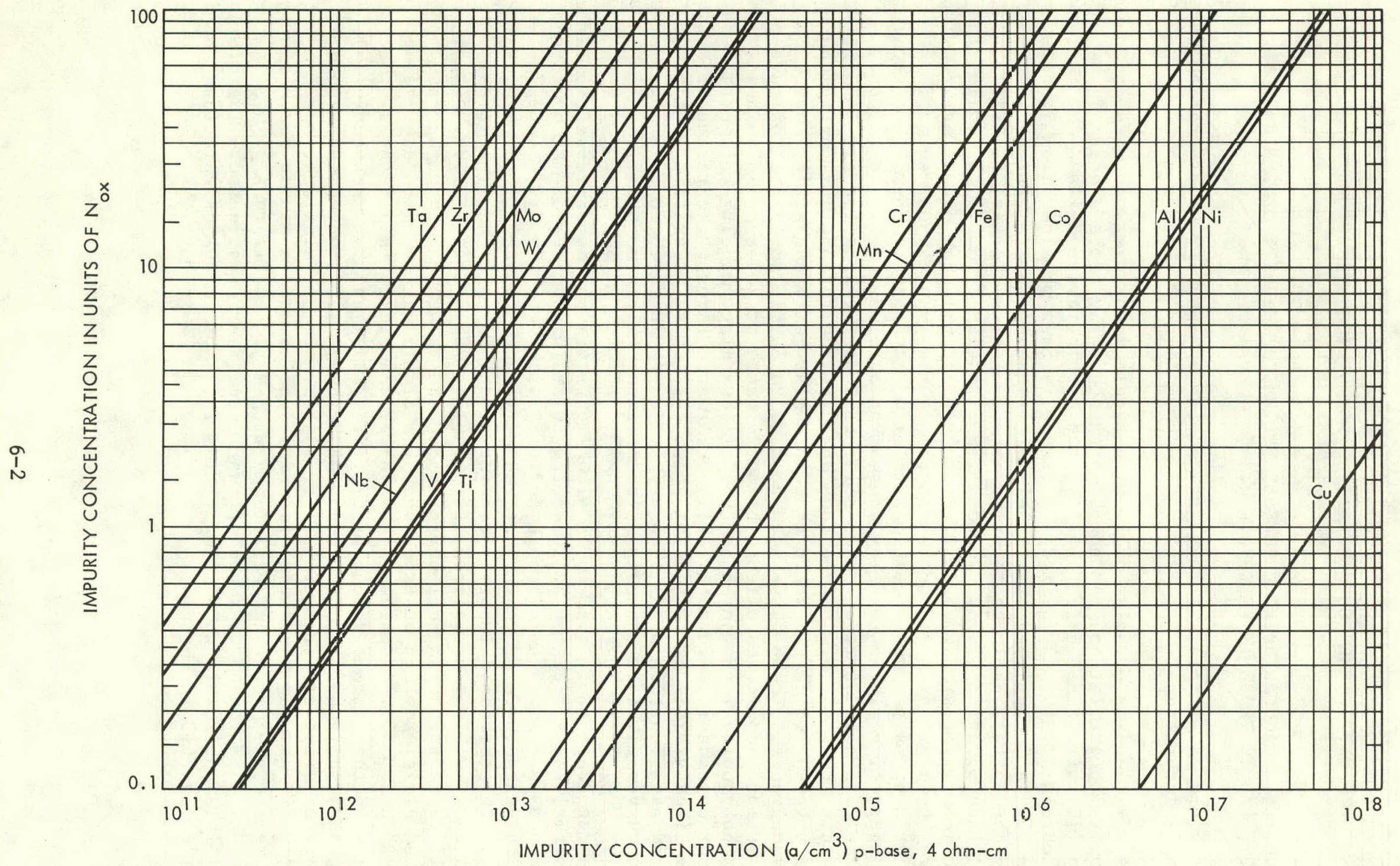

Figure 6-1a. Impurity Concentration in Solar Cell versus Impurity Concentration in Units of $\mathrm{N}_{\mathrm{ox}}, \mathrm{p}$-base, $\mathrm{a} / \mathrm{cm}^{3}$ 


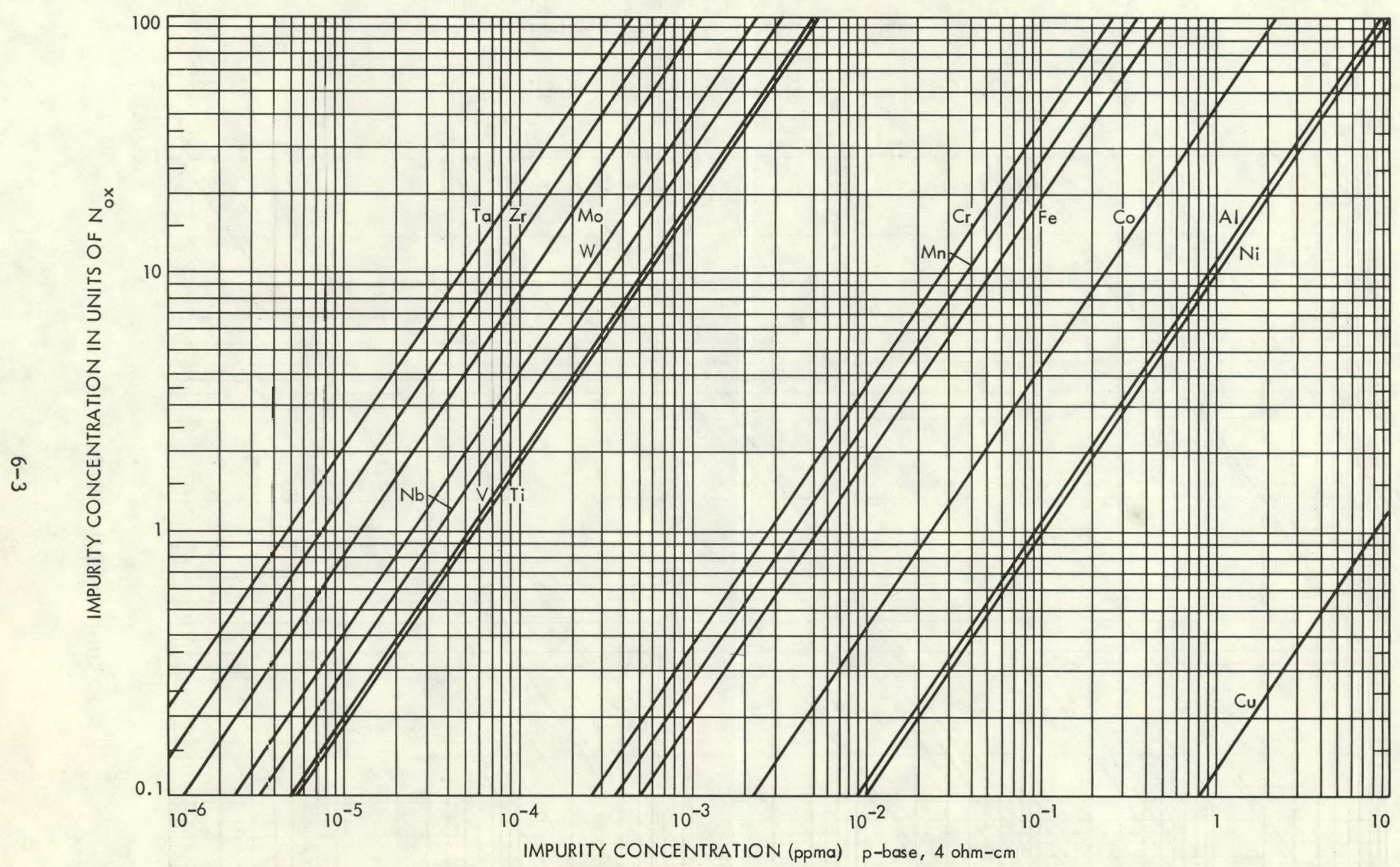

Figure 6-1b. Impurity Concentration in Solar Cell versus Impurity Concentration in Units of $\mathrm{N}_{\mathrm{ox}}$, p-base, ppma 


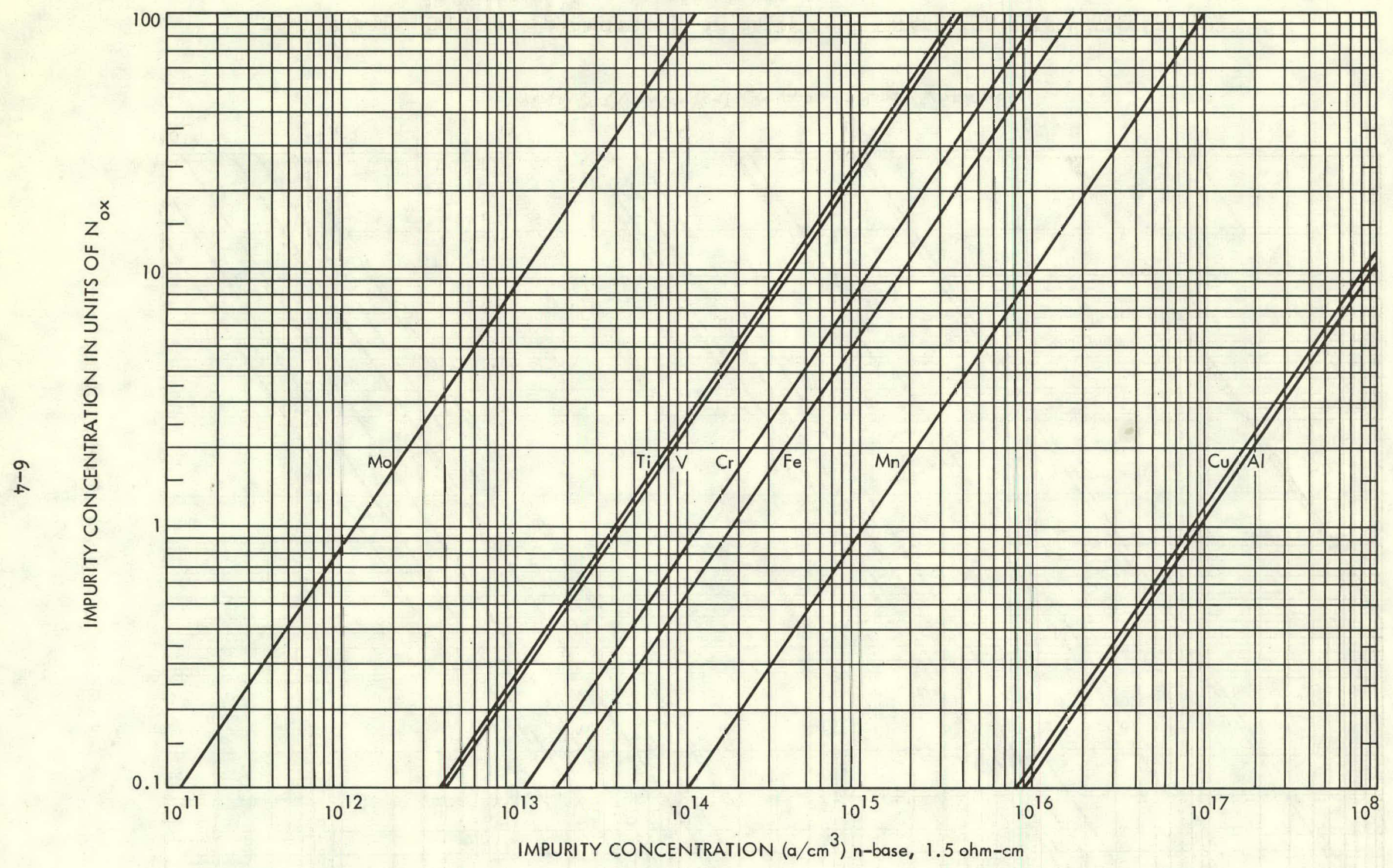

Figure 6-2E. Impurity Concentration in Solar Cell versus Impurity Concentration in Units of $\mathrm{N}_{\mathrm{ox}}, \mathrm{n}$-base, $\mathrm{a} / \mathrm{cm}^{3}$ 


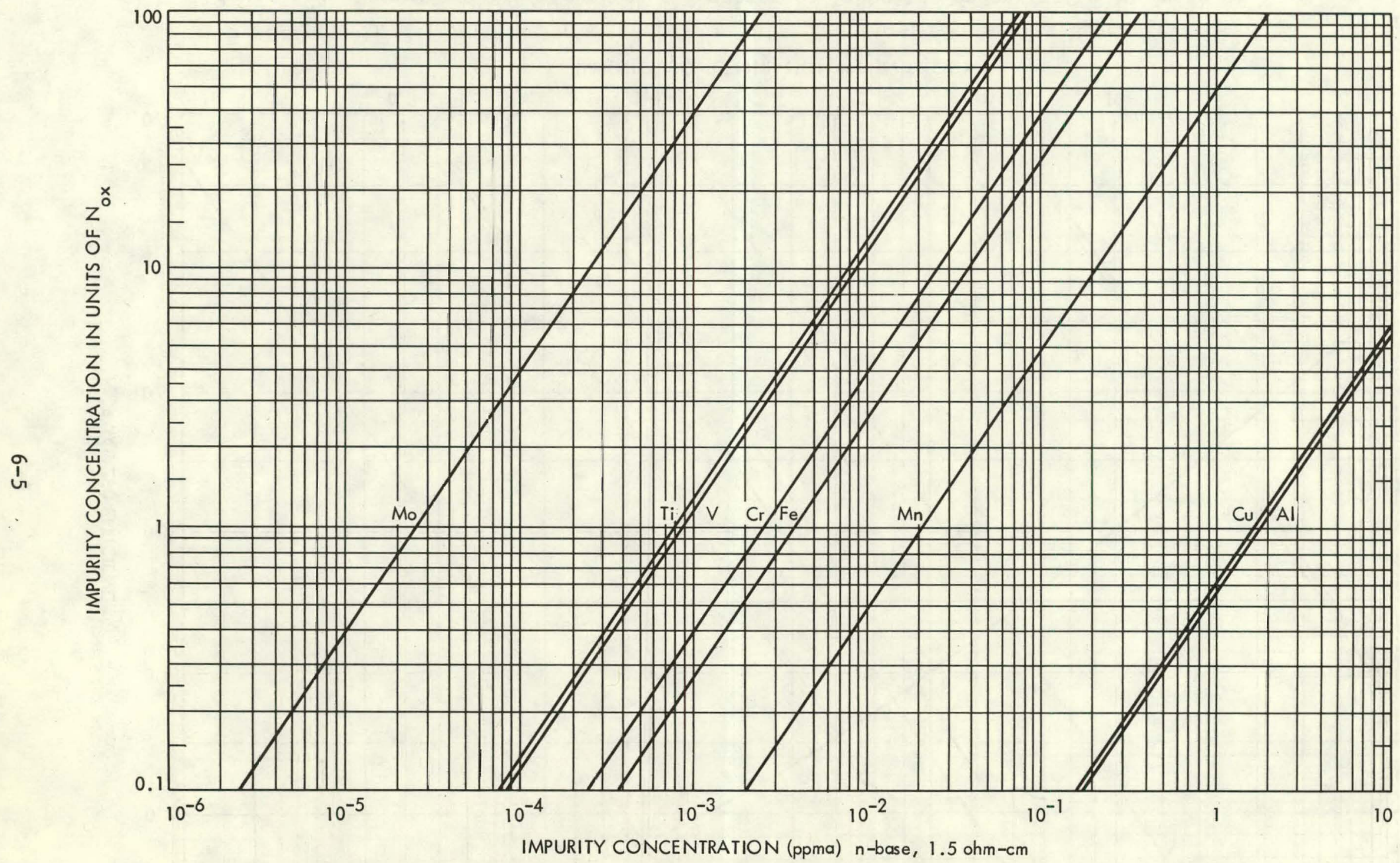

Figure 6-2b. Impurity Concentration in Solar Cell versus Impurity Concentration in Units of $\mathrm{N}_{\text {ox }}$, n-base, ppma 


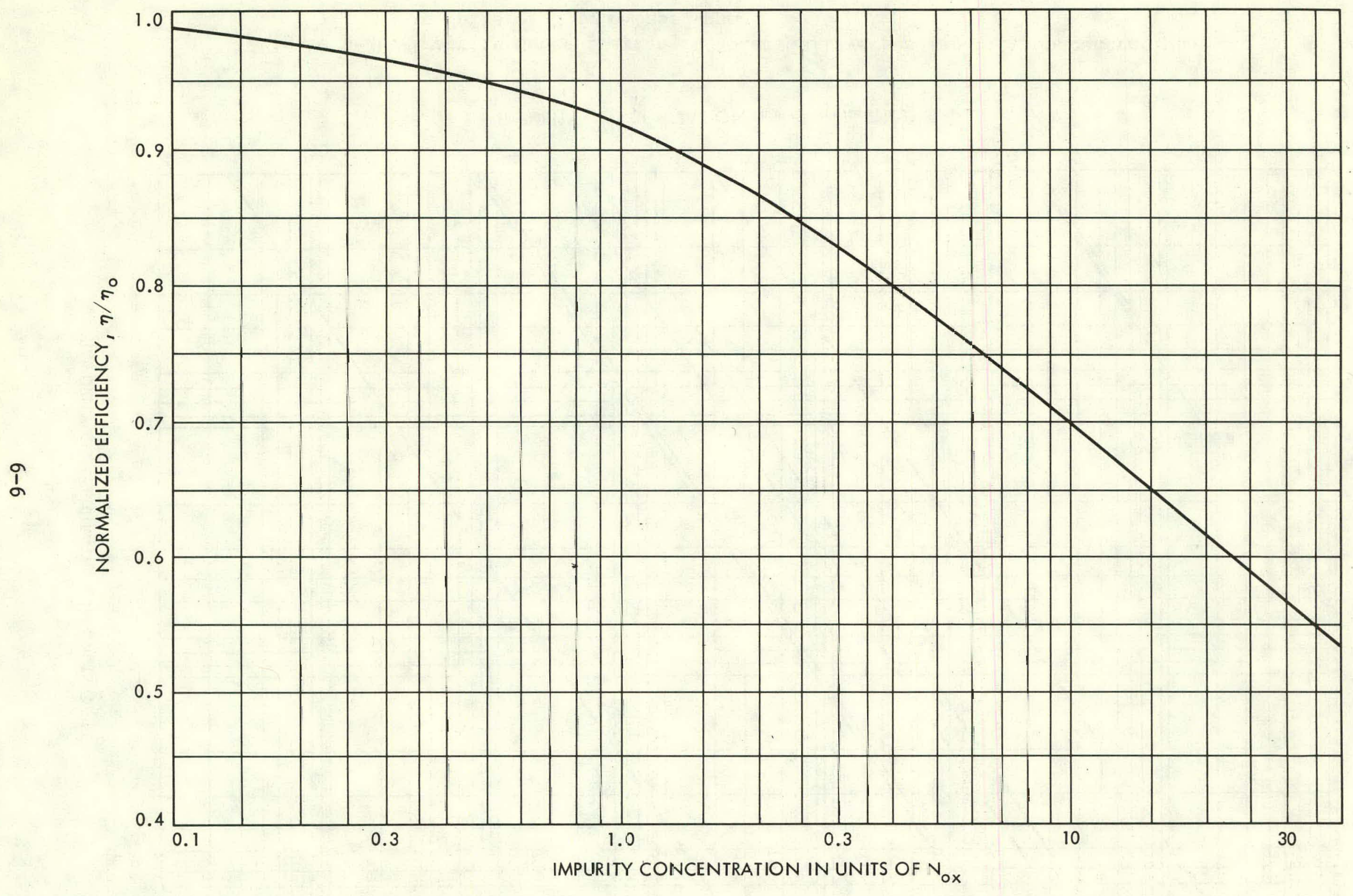

Figure 6-3. Normalizec Efficiency as a Function of Impurity Concentration in Units of $\mathrm{N}_{\mathrm{ox}}$ 


\section{Multiple Impurity Effects}

Where there are multiple impurities, Equation (8) gives the effects of these impurities on $I_{n}$ and thus on cell efficiency as the sum of the effects due to each impurity. Therefore, a calculation can be made of the expected performance of cells that contain multiple impurities at various concentration levels. The calculation includes the assumption that the impurities act independently. A comparison of calculated and experimental values makes possible an assessment of any interactive effects. Such a comparison was made (see Reference 1) and is shown in Figure 6-4 for typical studies on multiply-doped devices. The ingots are identified in Table 6-1. These data suggest a general anti-synergic behavior in that the calculated efficiencies are larger than the measured values. However, supplementary data (see Reference 1) obtained by dark current-voltage analysis and DLTS measurements show negligible impurity interactivity except for $\mathrm{Cu}$ with $\mathrm{Ti}, \mathrm{V}$, or $\mathrm{Zr}$ where the addition of Cu results in a small improvement in cell performance. The general downward displacement of the data was usually due either to junction degradation (precipitation) effects at higher total impurity concentrations that are not included in the calculations, or to inaccurate impurity concentration data. In general, impurities act independently, and the performance of solar cells with multiple impurities can be obtained by combining the effects produced by single impurities.

3. Application to Solar-Cell Manufacturing Processes Where No Redistribution of Impurities Occurs

The analysis presented in the previous section determines the tolerable concentration of impurities for solar-cell manufacturing processes where there is no redistribution of impurities in the feedstock during the manufacturing process. These processes include the edge-defined film growth method, the silicon-on-ceramic process, and various chemical vapor deposition methods.

\section{B. SOLAR-CELL MANUFACTURING PROCESSES WHERE REDISTRIBUTION OF IMPURITIES OCCURS}

The previous analysis is applicable to the definition of solar-grade silicon for silicon solar-cell manufacturing processes where no segregation of impurities from the feedstock occurs. However, for manufacturing processes where unidirectional freezing, under near equilibrium conditions, is an integral step in the process, as in Czochralski growth of single crystals, there is a redistribution of impurities during the growth process. This redistribution results in a reduction of the impurity content in the grown crystal.

To define solar-grade silicon for these processes, the partial removal of impurities from the feedstock during the growth process must be considered. Various processes, including the web dendrite method, and the heat exchanger method, are included in this group. There are only minor differences in the effective segregation coefficients for these methods, the magnitudes depending on the degree to which the growth conditions approach equilibrium conditions. For example, the effective segregation coefficients for web dendritic growth 


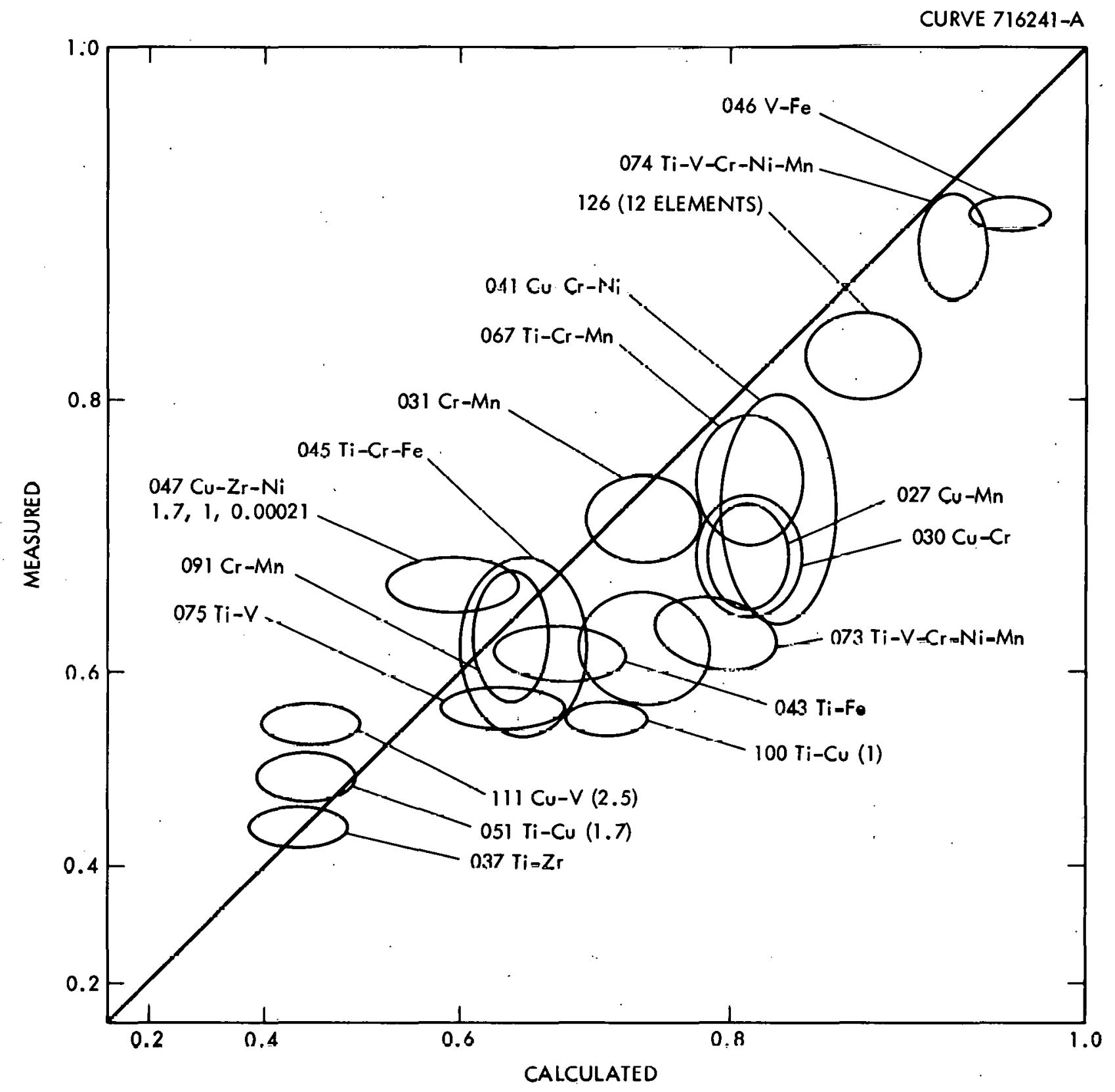

Figure 6-4. Normalized Efficiencies for Multiply-Doped 4 ohm-cm p-Base Solar Cells 

Table 6-1. Impurity Concentrations for Multiply-Doped Ingots
in Figure $6-5\left(10^{15} \mathrm{a} / \mathrm{cm}^{3}\right)$

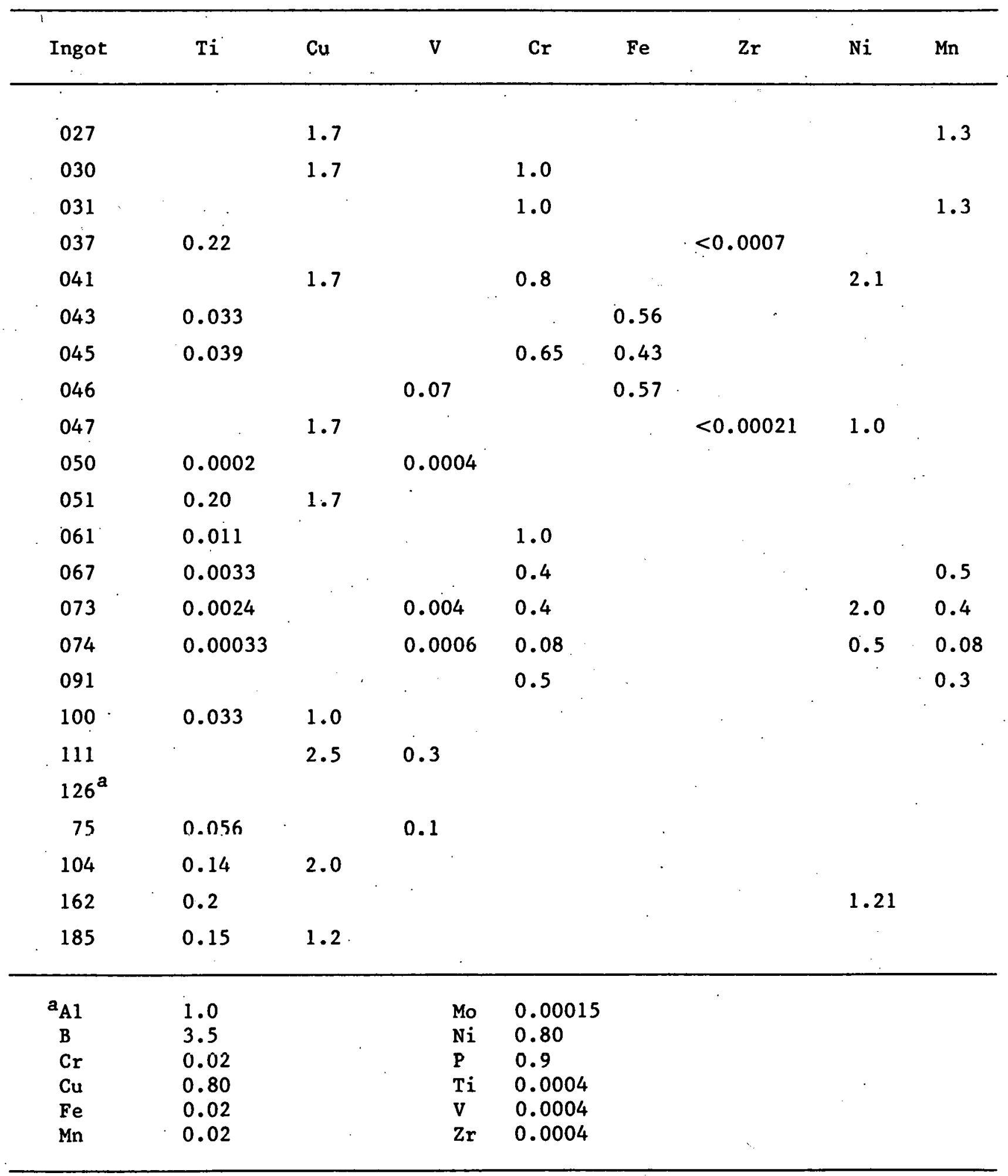


are about a factor of two larger than for Czochralski growth, and those for the heat exchanger method could be lower than for Czochralski growth because of the slow rate of solidification used. In Section VII, the effects of unidirectional solidification on the tolerable concentration of impurities in silicon feedstock are illustrated.

1. Impurity Buildup for Sequential Melt Replenishment

The equation giving the distribution of the impurities in the melt and in the crystal grown is given by (see Reference 1):

$$
c^{L}=c_{0}^{L}(1-g)^{k-1}
$$

where

$$
\begin{aligned}
& \mathrm{C}^{\mathrm{L}}=\text { impurity concentration in the melt } \\
& \mathrm{C}_{0}^{\mathrm{L}}=\text { initial impurity concentration } \\
& \mathrm{k}=\text { segregation coefficient (Table } 3-2) . \\
& \mathrm{g}=\text { fraction of the melt grown }
\end{aligned}
$$

For small segregation coefficients, $k$, such as those for most metallic impurities, Equation (22) can be approximated by

$$
c^{L}=\frac{c_{0}^{\top}}{1-g}
$$

so that

$$
\mathrm{c}^{\mathrm{s}}-\mathrm{kC}^{\mathrm{L}}
$$

where $\mathrm{C}^{\mathrm{S}}$ is the impurity concentration in the crystal. This approximation holds for all of the impurities considered except for boron and phosphorus which have segregation coefficients that are large, and are considered separately in Section VIII. During crystal growth there is an initial lowering of the impurity concentration in the grown crystal by a factor of $k$, the segregation coefficient. However, there is a subsequent buildup in impurity concentration as the crystal ingot is grown. The impurity concentration in the crystal depends on the fraction of the melt grown into a single crystal. For sequential melt replenishment, the impurity buildup in the melt progresses with the number of replenishments. For impurities where $k<<1$, as for most of the impurities considered, the concentration of impurities in the melt can be approximated by (see Reference 2): 


$$
c^{S}(x)=c_{0}^{L}\left(1+\frac{n g}{1-g}\right)
$$

where $n$ is the number of sequential replenishments and $g$ the fraction of the melt frozen between replenishments.

Figure 6-5 gives the impurity concentration buildup as a function of the number of replenishments used per crucible for Czochralski growth for various fractions of the melt grown before replenishments. For $90 \%$ of the melt grown before replenishments, the impurity concentration is built up by a factor of 10. For 5 replenishments per crucible the impurity is built up by a factor of 46 .

\section{Impurity Buildup for Continuous Melt Replenishment}

For continuous melt replenishment (see Reference 1), the melt volume remains constant. As an incremental volume of the crystal is grown from the melt, an equal volume of feedstock material is added. The change in impurity content in the melt is

$$
v_{o} d c^{L}=\left(c_{o}^{L}-k c^{L}\right) d v_{c}
$$

where $v_{c}=$ volume of crystal grown and $v_{0}$ the volume of the melt.

By integrating and applying the condition that $\mathrm{C}^{\mathrm{L}}=\mathrm{C}_{0}^{\mathrm{L}}$ when $v_{c}=0$ we have

$$
\frac{c^{L}}{c_{0}}=\frac{1}{k}\left[1-(1-k) \exp \left(\frac{-k V_{c}}{v_{0}}\right)\right]
$$

when

$$
\frac{\mathrm{kV}}{\mathrm{c}} \mathrm{v}_{\mathrm{o}}<1
$$

Equation (27) becomes

$$
\frac{c_{1}}{c_{0}} \simeq 1+\frac{v_{c}}{v_{0}}
$$




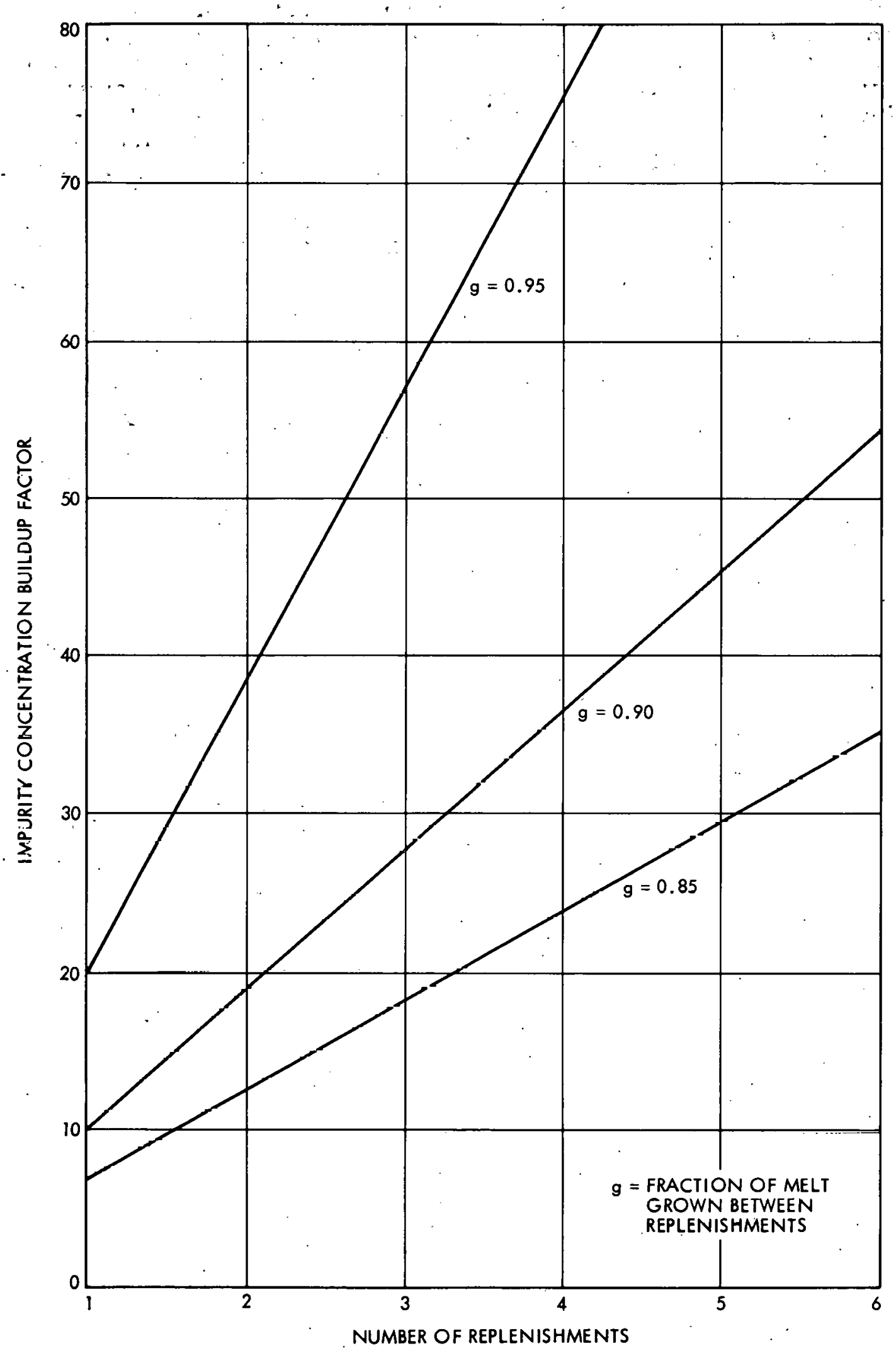

Figure 6-5. Impurity Concentration Buildup for Sequential Replenishment 
Figure 6-6 gives the impurity concentration buildup for continuous replenishment. Figures $6-7 \mathrm{a}$ and $6-7 \mathrm{~b}$ give the impurity concentration in the feedstock silicon for $90 \%$ of the melt grown (i.e., $g=0.9$ and an impurity concentration buildup factor of 10) as a function of $\mathrm{N}_{\mathrm{Ox}}$ for different impurities in p-base material in $\mathrm{a} / \mathrm{cm}^{3}$ and ppma, respectively. These curves can be used with the relationship between $N_{o x}$ and the normalized efficiency given in Figure 6-3 and in Figures $A-1$ through $A-7$ in Appendix $A$ to determine tolerable concentrations of impurities in silicon feedstock for solar-cell manufacturing processes using unidirectional freezing of molten silicon by first determining the impurity concentration buildup factor given in Figures 6-5 and 6-6 for the specific process used. 


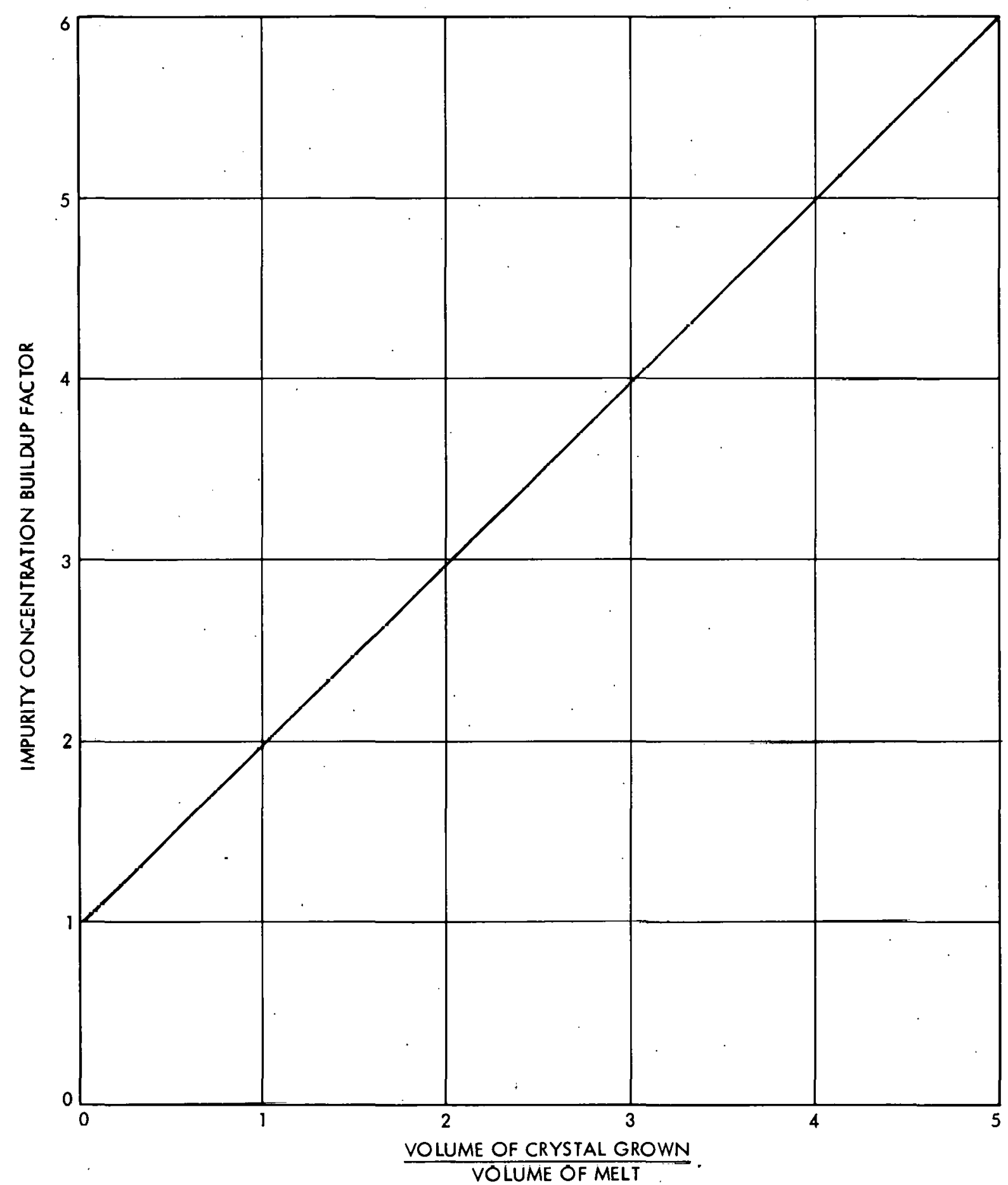

Figure 6-6. Impurity Concentration Buildup for Continuous Replenishment 


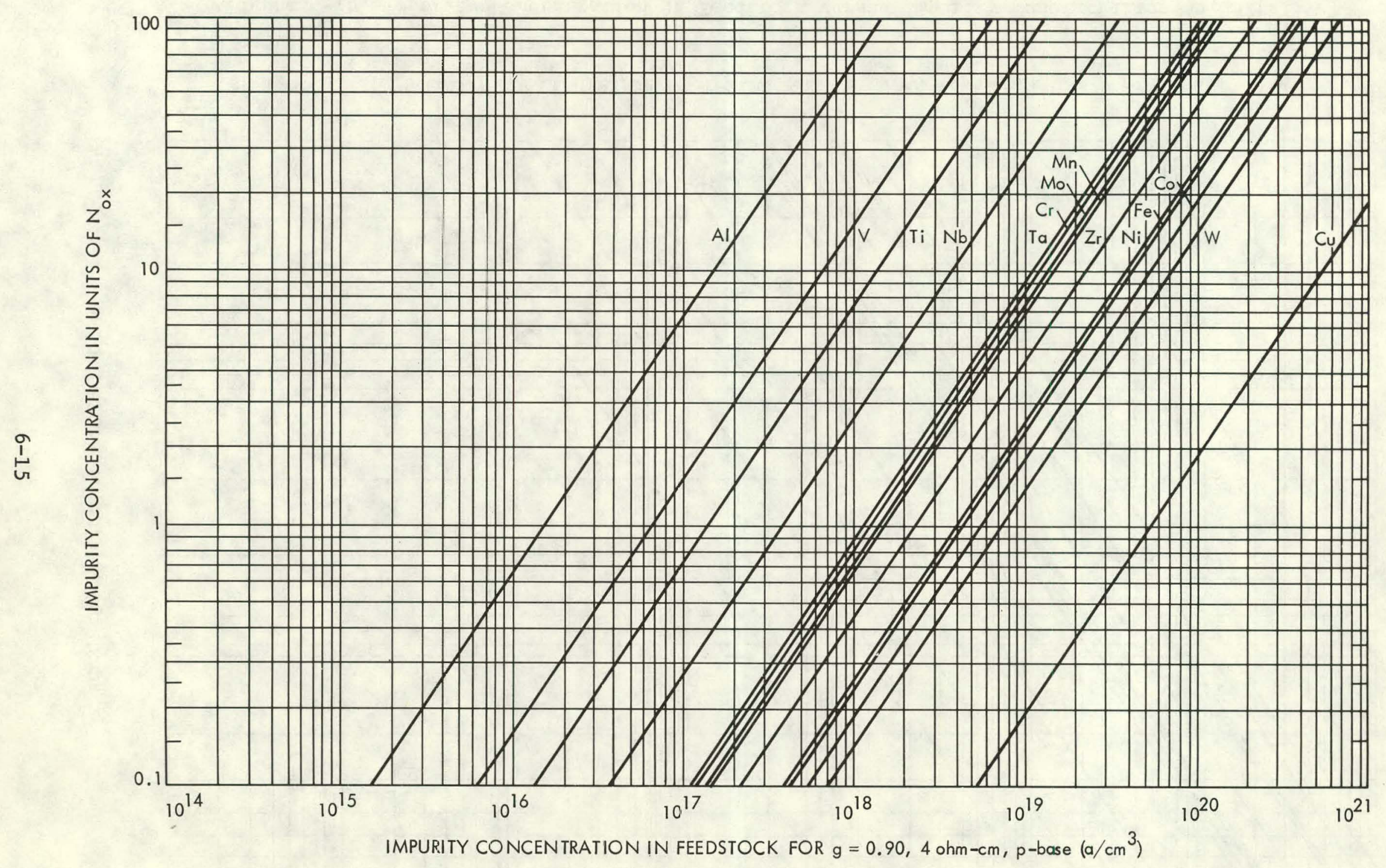

Figure 6-7a. Impurity Concentration in Feedstock versus Impurity Concentration in Units of $\mathrm{N}_{\text {ox }}, \mathrm{a} / \mathrm{cm}^{3}$ (Czochralski Growth) 


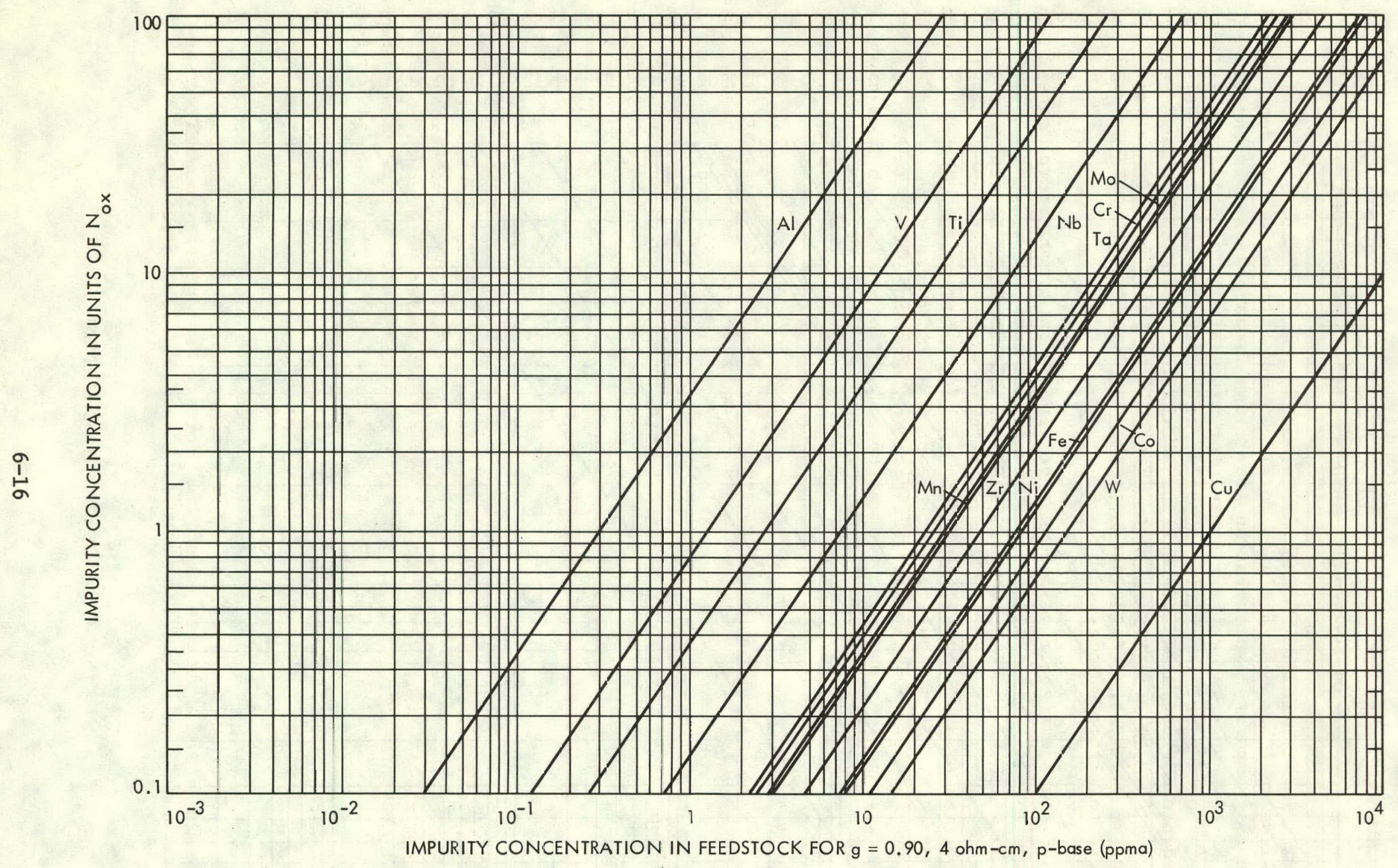

Figure 6-7b. Impurity Concentration in Feedstock versus Impurity Concentration in Units of $\mathrm{N}_{\text {ox }}$, ppma (Czociralski Growth) 
SECTION VII

SILICON SOLAR-CELL IMPURITY EFFECTS SLIDE RULE

A slide rule has been designed to aid in the calculations to determine the tolerable impurity concentration in silicon feedstock used in the manufacture of silicon solar cells. A need for calculations of this type arises because the effects of impurities on solar-cell performance are not only species-dependent but are different for the various processes to be developed for the Low-Cost Solar Array Project. The rule is based on the analysis given in the previous sections and uses the approximation that Figure 6-3 is applicable to all impurities.

The processes to be developed can be divided into two general cases. In Case I the manufacturing process is performed without redistribution of impurities in the silicon feedback. That is, the impurity concentration in the solar cells is essentially the same as that in the feedstock material. This condition occurs in the edge-defined film growth process, the silicon-onceramic process, and various chemical vapor deposition processes. In Case II, a redistribution of impurities in the silicon feedstock occurs in the cell manufacturing process, during unidirectional freezing of silicon from the melt, under conditions reasonably close to equilibrium. This condition exists for the Czochralski process with and without replenishment of the melt, the web dendrite process, and the heat exchanger process.

The rule is applicable to both cases. The degradation in solar-cell performance is calculated in terms of the normalized efficiency of the cell as a function of the impurity concentration in the siliçon feedstock in ppma. A conversion scale is provided to convert ppma to $\mathrm{a} / \mathrm{cm}^{3}$. Impurity concentration buildup during crystal growth for the various ingot processes can be calculated as a function of the number of replenishments used and the fraction of melt grown $(\mathrm{g})$ between replenishments.

\section{SAMPLE CALCULATION}

Figure 7-1 shows a picture of the slide rule. Scales 1 and 2 are used to calculate the tolerable concentrations of specific impurities in silicon feedstock where no redistribution of impurities occurs in the manufacturing process (Case I). Figure 7-2 gives an example of how to determine the allowable concentration of iron in the silicon feedstock for this case. The rule is set for iron (A). The impurity concentration in ppma is read for the allowable degradation in cell efficiency. The allowable iron concentration for a $10 \%$ degradation in cell performance is about $7 \times 10^{-3}$ ppma (B).

Scales 3, 4 and 5 are used to calculate the tolerable impurity concentrations in the silicon feedstock where redistribution of impurities occurs during unidirectional freezing of silicon under near equilibrium conditions as in the Czochralski process (Case II). First, the impurity concentration buildup factor shown as the IB Factor in Figure 7-3 is determined for the specific process used. 


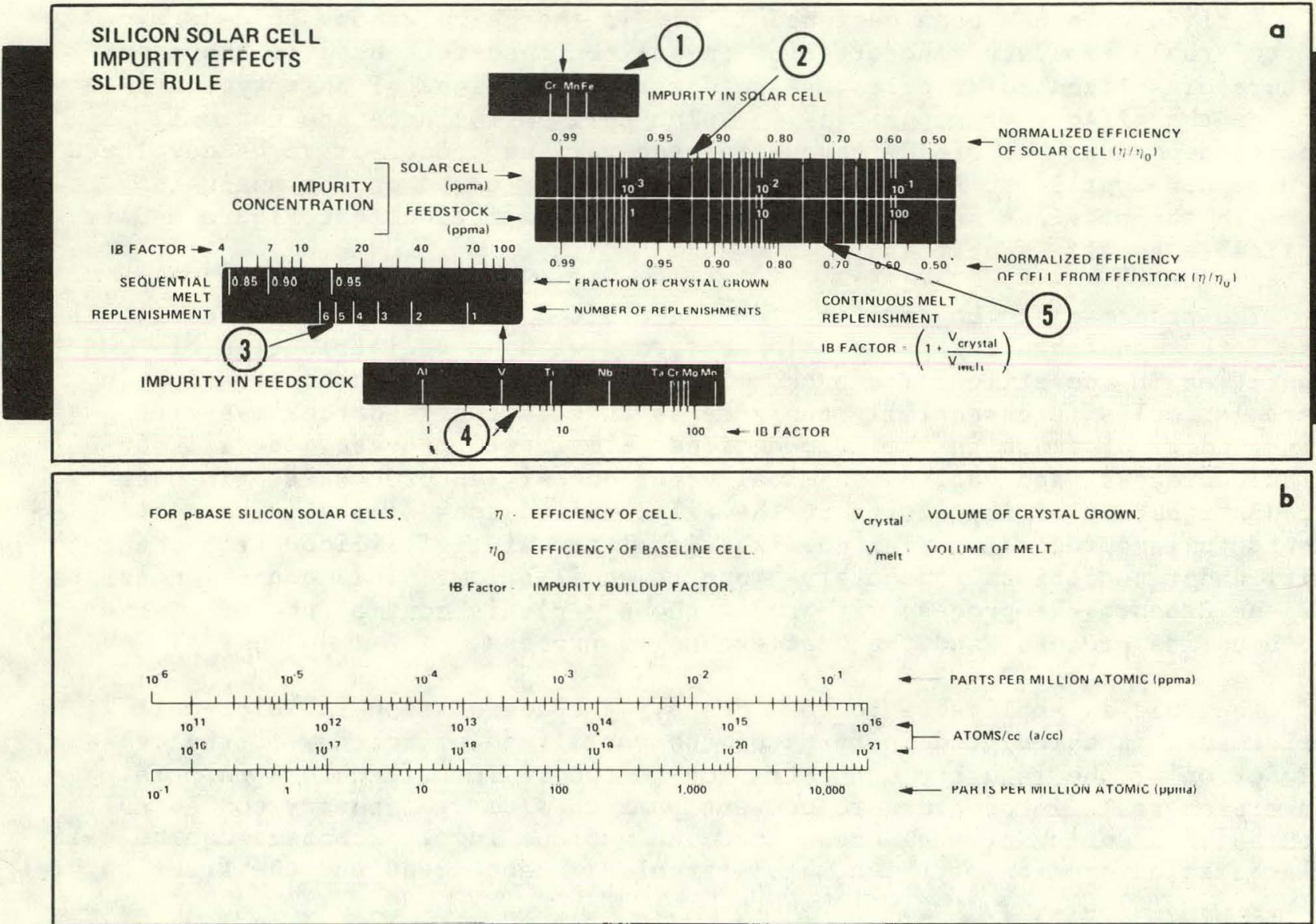

\section{Case I}

Use scales 1 and 2 for solar-cell manufacturing processes where the impurity concentration in the cells is equal to that in the feedstock.

\section{Case II}

Use scales 3, 4, and 5 for solar-cell manufacturing processes where redistribution of impurities in the feedstock occurs because of segregation of impurities during crysta1 growth.

Figure 7-1. Slide Rule (a - Front, b - Back) 


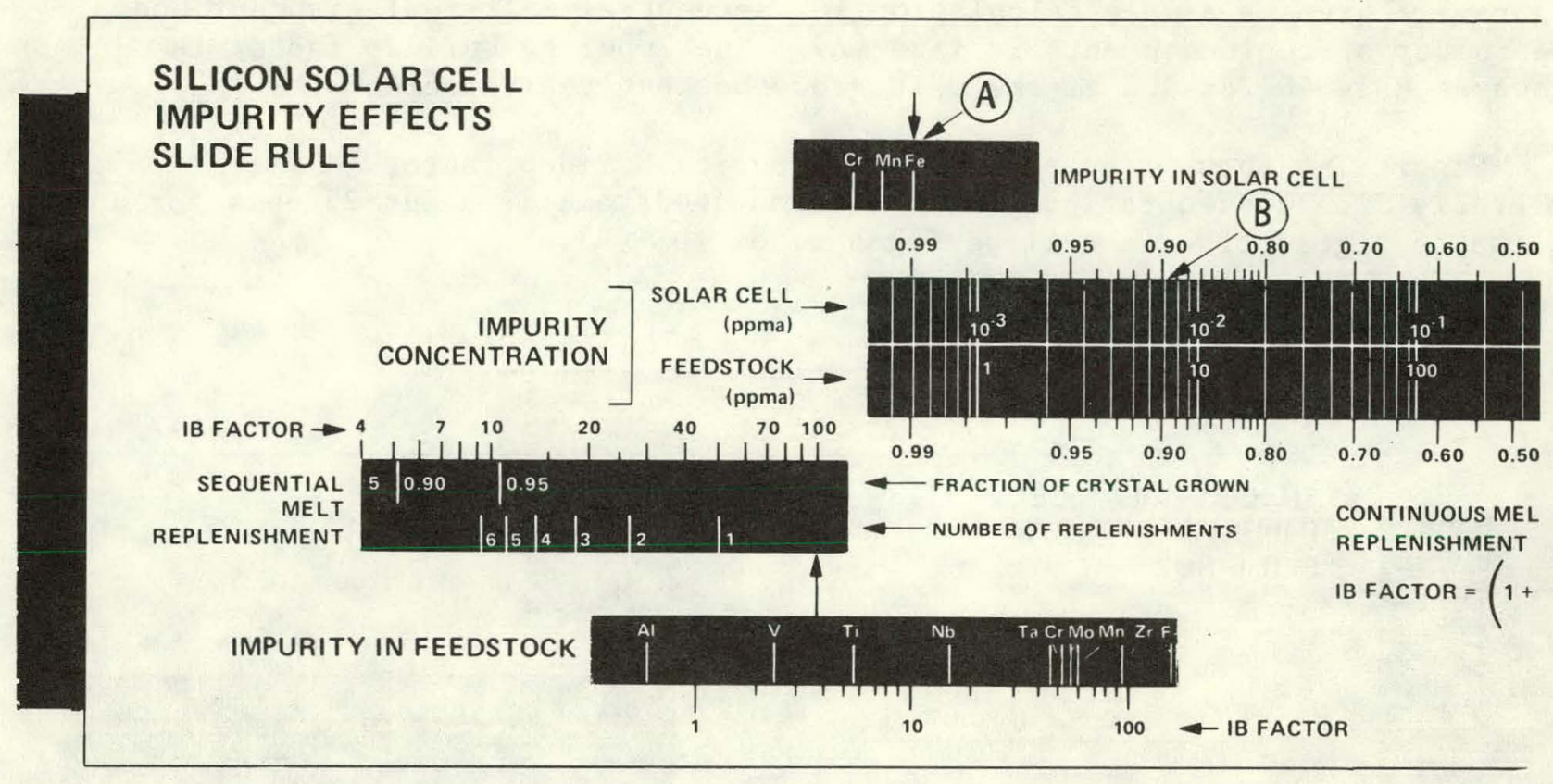

Figure 7-2. Scale Set for Fe for Case I at (A). Impurity Concentration in Solar Cell for $10 \%$ Degradation in Efficiency $7 \times 10^{-3}$ ppma

\section{SILICON SOLAR CELL IMPURITY EFFECTS SLIDE RULE}

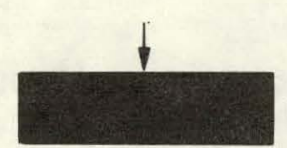

IMPURITY IN SOLAR CELL

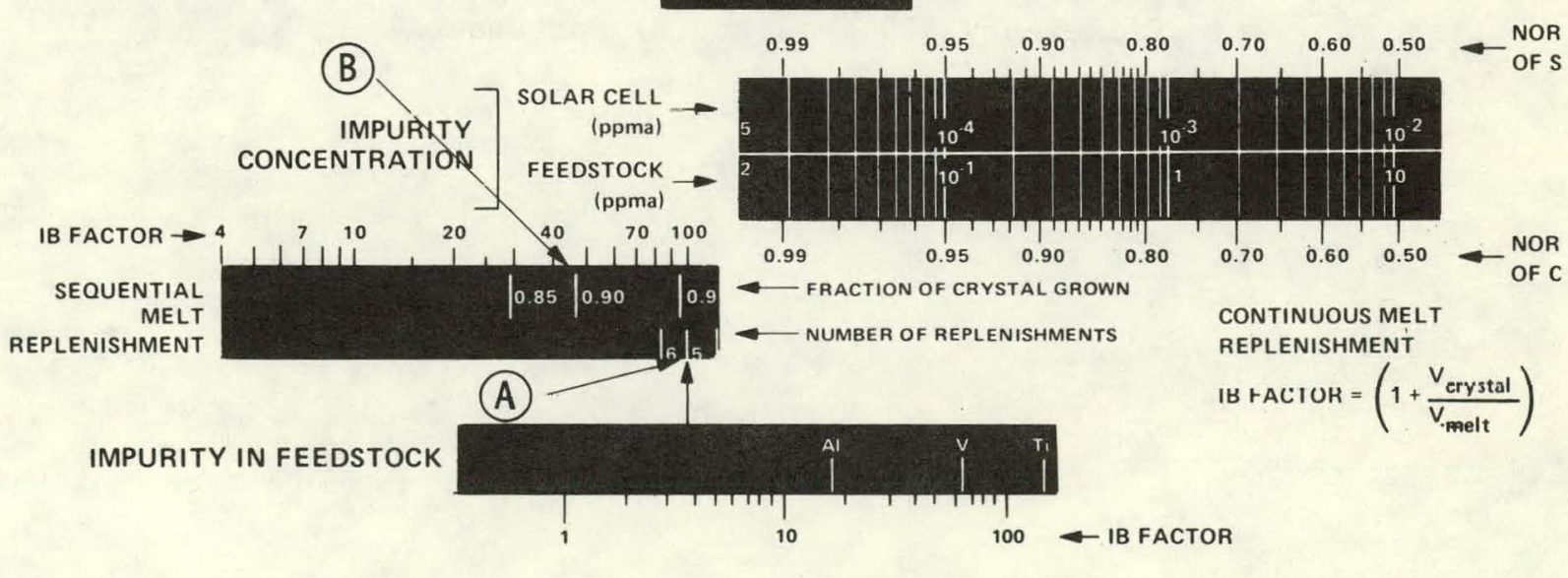

Figure 7-3. Scale Set for Five Replenishments for Case II at (A). Impurity Buildup Factor of 46 is Obtained at (B) 
Figure 7-3 gives a sample calculation for sequential melt replenishment where the number of replenishments is five (A). The impurity buildup factor is shown at $B$ as 46 for $90 \%$ of the melt grown between replenishments.

Figure 7-4 shows iron set at this impurity buildup factor (A). The tolerable iron concentration in the silicon feedstock is about 25 ppma for an allowable degradation in cell performance of $10 \%$ (B).

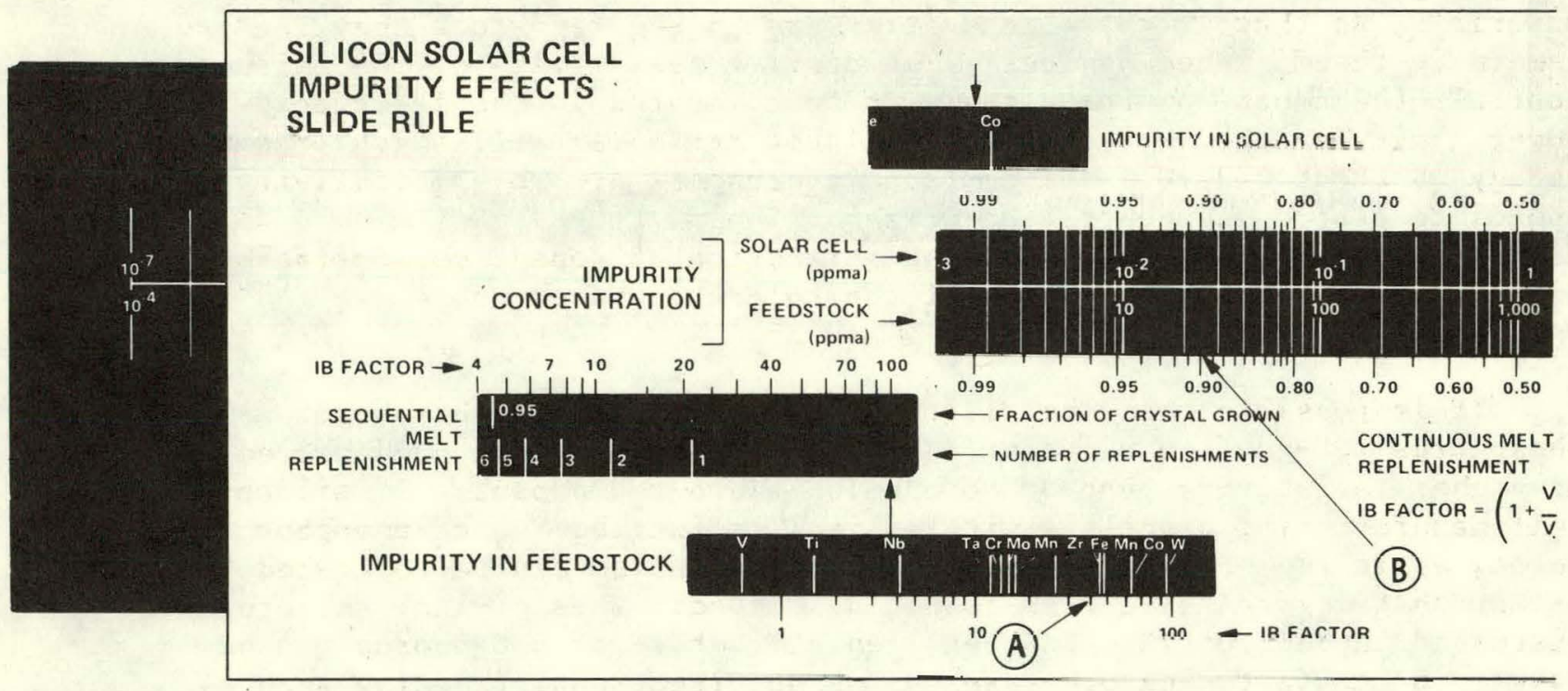

Figure 7-4. Scale Set at Impurity Buildup Factor of 46 for $\mathrm{Fe}$ at (A). Impurity Concentration in Feedstock for 10\% Degradation in Efficiency, 25 ppma at (B) for Case II 


\section{SECTION VIII}

\section{BORON AND PHOSPHORUS}

Boron and phosphorus occur in metallurgical-grade silicon (see Table 2-1). Although these elements are the common dopants used in making solar cells, their uncontrolled presence in silicon feedstock may lead to base material that is too low in resistivity or is highly compensated. These "impurities" are treated separately because they differ from the other impurities considered here in that their segregation coefficients are large: 0.8 for boron and 0.35 for phosphorus. They have also proved to be difficult to remove from silicon materials, so that if these impurities are in the feedstock they tend to remain in the finished devices. The desired resistivity of the silicon controls the amount of boron that can be tolerated in the feedstock. The lower limit for the resistivity of silicon for solar cells with present technology is about $0.3+0.1 \mathrm{ohm}-\mathrm{cm}$ (see Reference 17). This resistivity corresponds to a boron concentration of about 2 ppma (i.e., $10^{17} \mathrm{a} / \mathrm{cm}^{3}$ ) as shown in Figure 8-1 where the resistivity as a function of dopant concentration is given. This is the upper limit of the tolerable boron concentration in the feedstock.

It is possible that the silicon feedstock contains phosphorus or that phosphorus is added to silicon feedstock which results in compensated material of higher resistivity than if boron alone were the dopant. In silicon solarcell manufacturing processes with minimal redistribution of phosphorus and boron, as in edge-defined film growth, compensation can be tolerated to the extent that crystal structure is not disturbed. This crystal structure is discussed in Section IX. However, redistribution of phosphorus and boron occurs in manufacturing processes using unidirectional freezing such as Czochralski growth because of the difference in the segregation coefficients of boron and phosphorus. This causes a yield problem that limits the degree of compensation tolerable in the feedstock material. Equation (22) gives the concentration of impurity in the melt as a function of the initial concentration of impurity in the solid crystal, $\mathrm{C}^{\mathrm{S}}$, and the impurity concentration is obtained by using Equation (24) as:

$$
C^{S}=k C_{0}^{L}(1-g)^{k-1}
$$

By using Equation (25) for the initial concentration of boron and phosphorus, the resistivity of the grown ingot is calculated for various initial resistivities of the compensated silicon (i.e., $1,0.5,0.3$, and $0.1 \mathrm{ohm}-\mathrm{cm}$ ) and for various amounts of compensation by phosphorus. The results are given in Figures 8-2a through 8-2d. The resistivity of the compensated silicon rises with $g$, the fraction of the melt frozen, and converts from $p$ - to n-type for highly compensated ingots. This rise in resistivity with the fraction of melt grown sets a limit to the yield of usable silicon grown from compensated silicon. It is reasonable to consider a factor of 2 rise in resistivity as a cut-off value because the resistivity rises rapidly after this point. In Figure 8-3 the effect of multiple replenishment growth on phosphorus buildup has been calculated. 


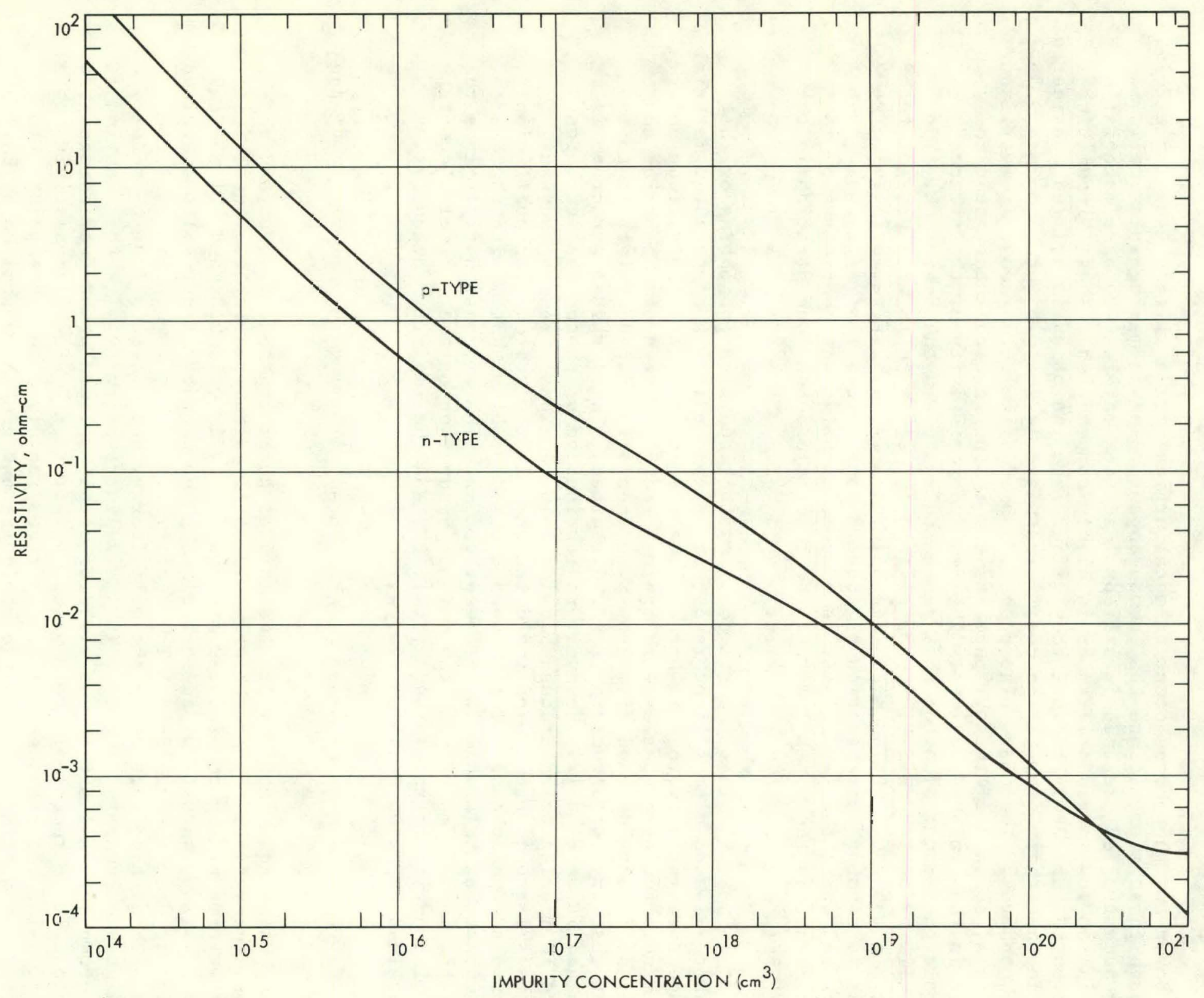

Figure 8-1. Resistivity of Silicon at $300^{\circ} \mathrm{K}$ as a Function of Acceptor or Dozor Concentration (See Reference 18) 


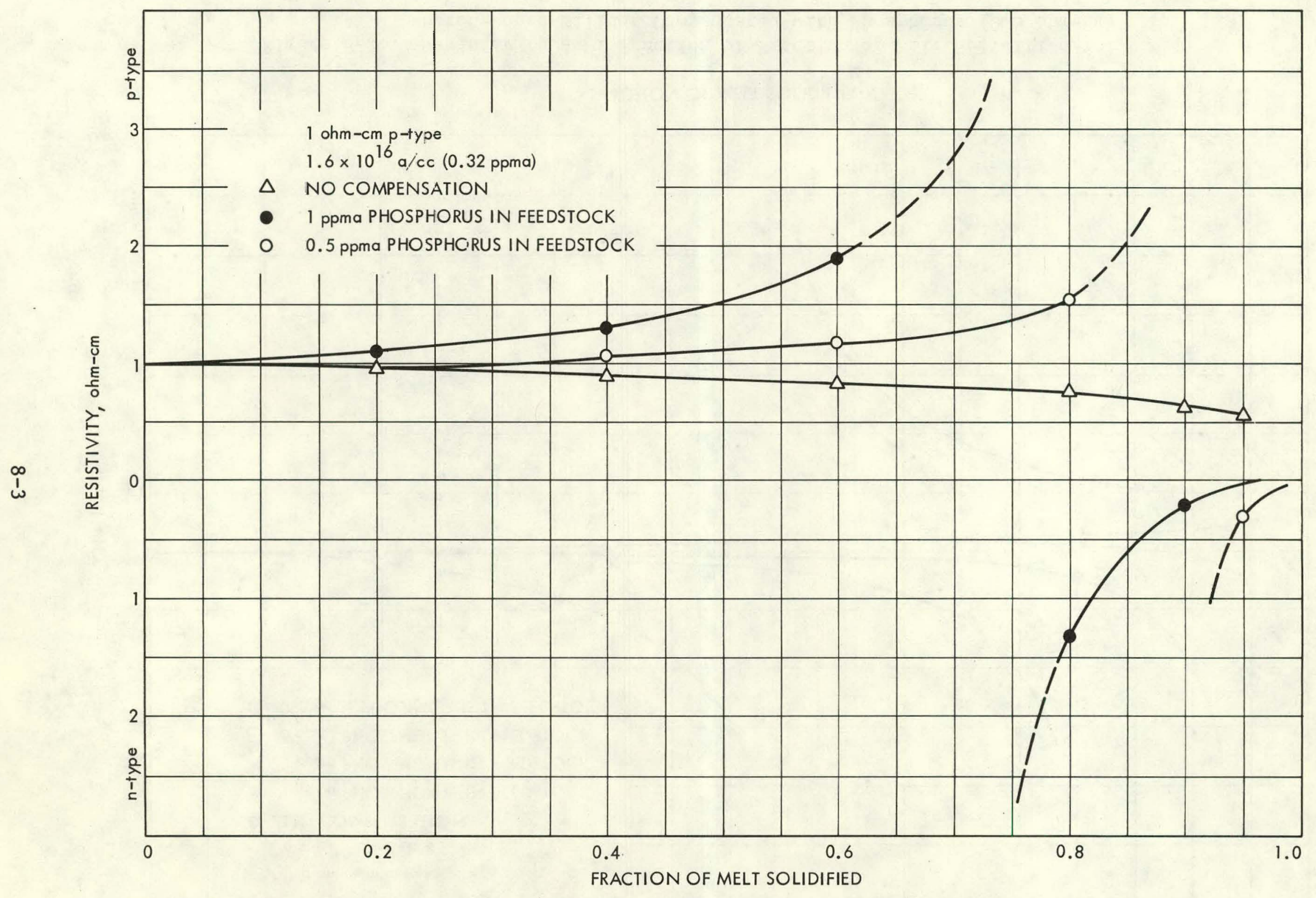

Figure 8-2a. Resistivity as a Function of Fraction of Melt Solidified for Boron-Doped Silicon Compensated with Phosphorus (1 ohm-cm) 


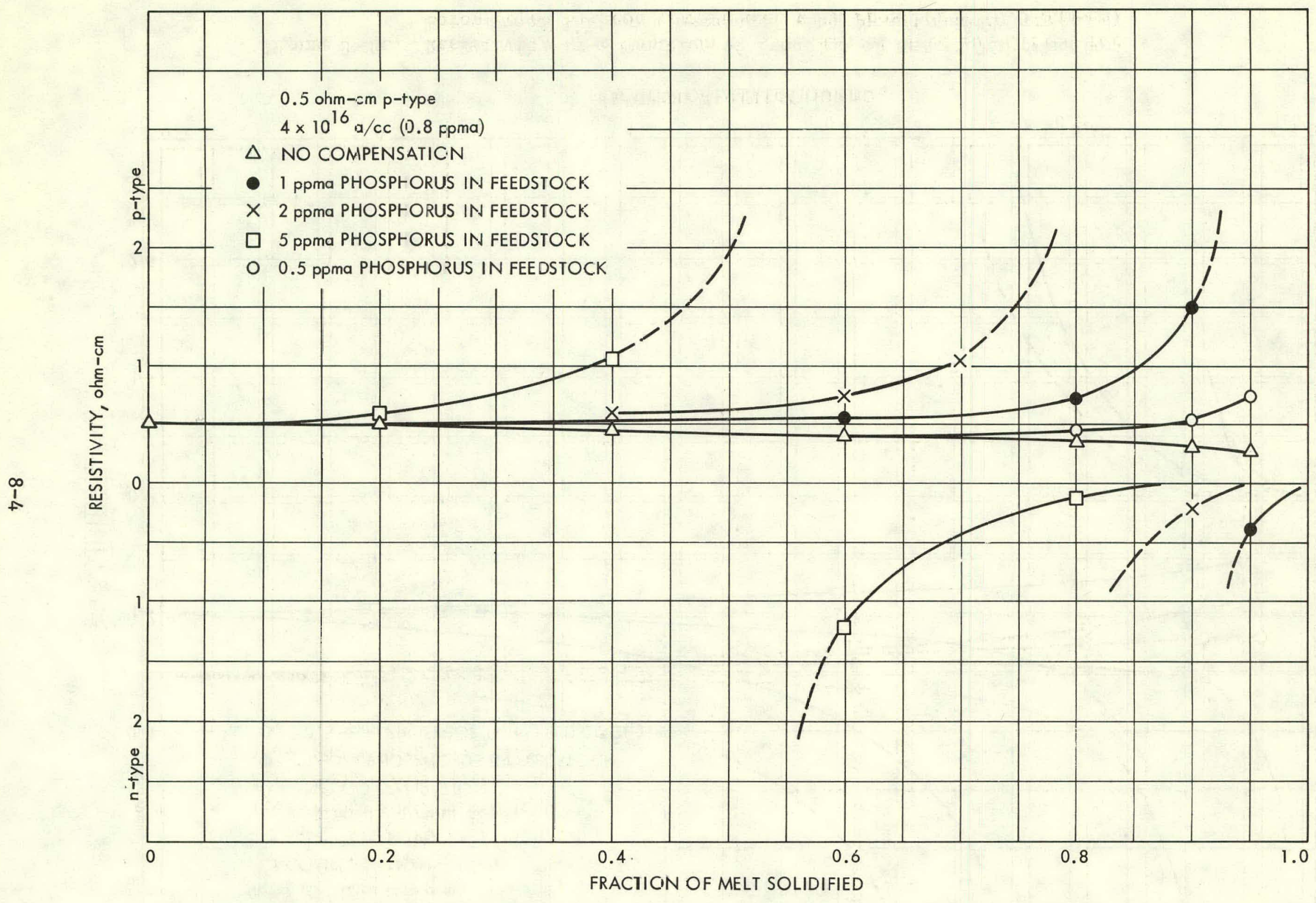

Figure 8-2b. Resistivity as a Function of Fraction of Melt Solidified for Bcron-Doped Si-icor Compensated with Phospiorus $(0.5 \mathrm{ohm}-\mathrm{cm}$ ) 


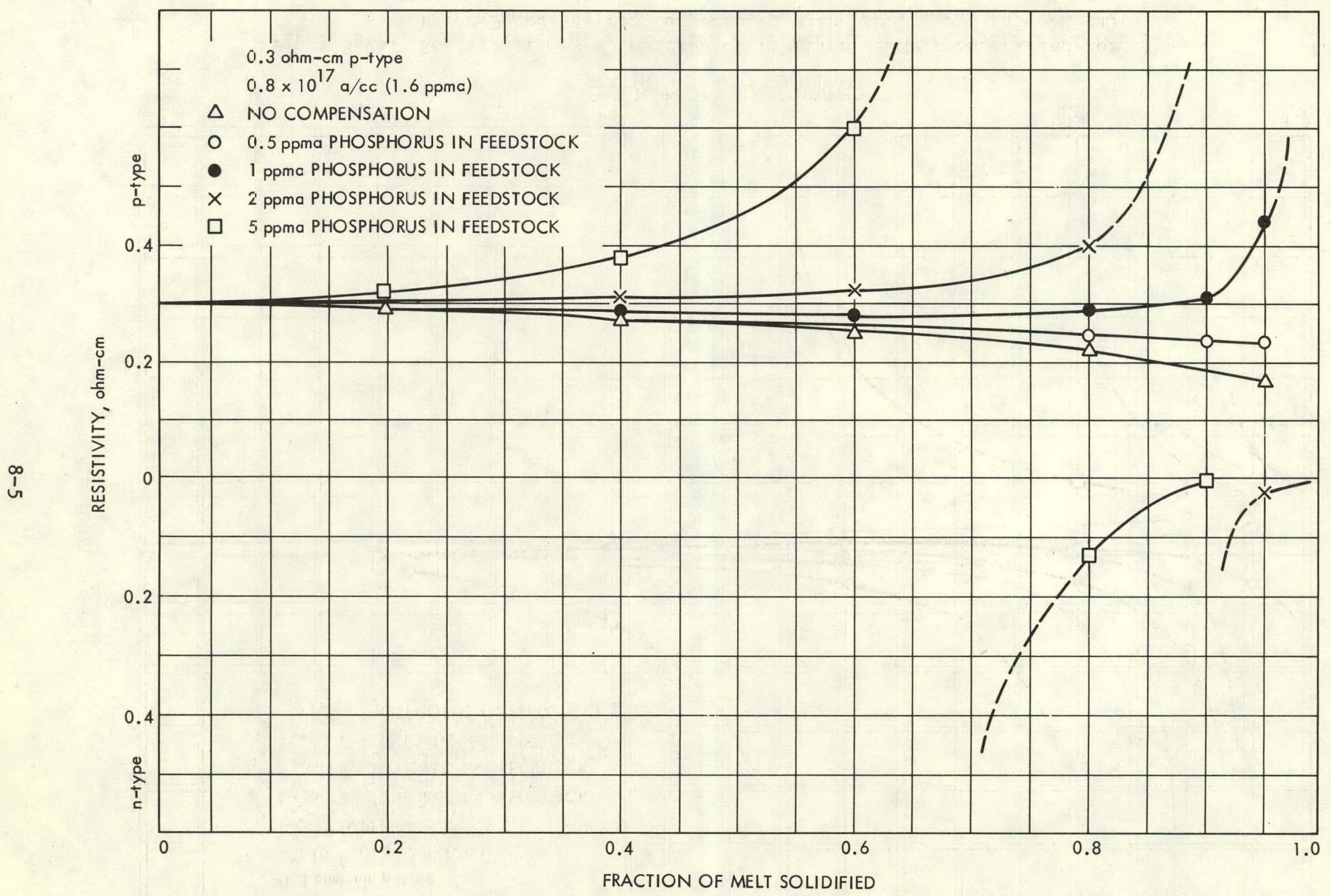

Figure 8-2c. Resistivity as a Function of Fraction of Melt Solidified for Boron-Doped Silicon Compensated with Phosphorus $(0.3 \mathrm{ohm}-\mathrm{cm})$ 


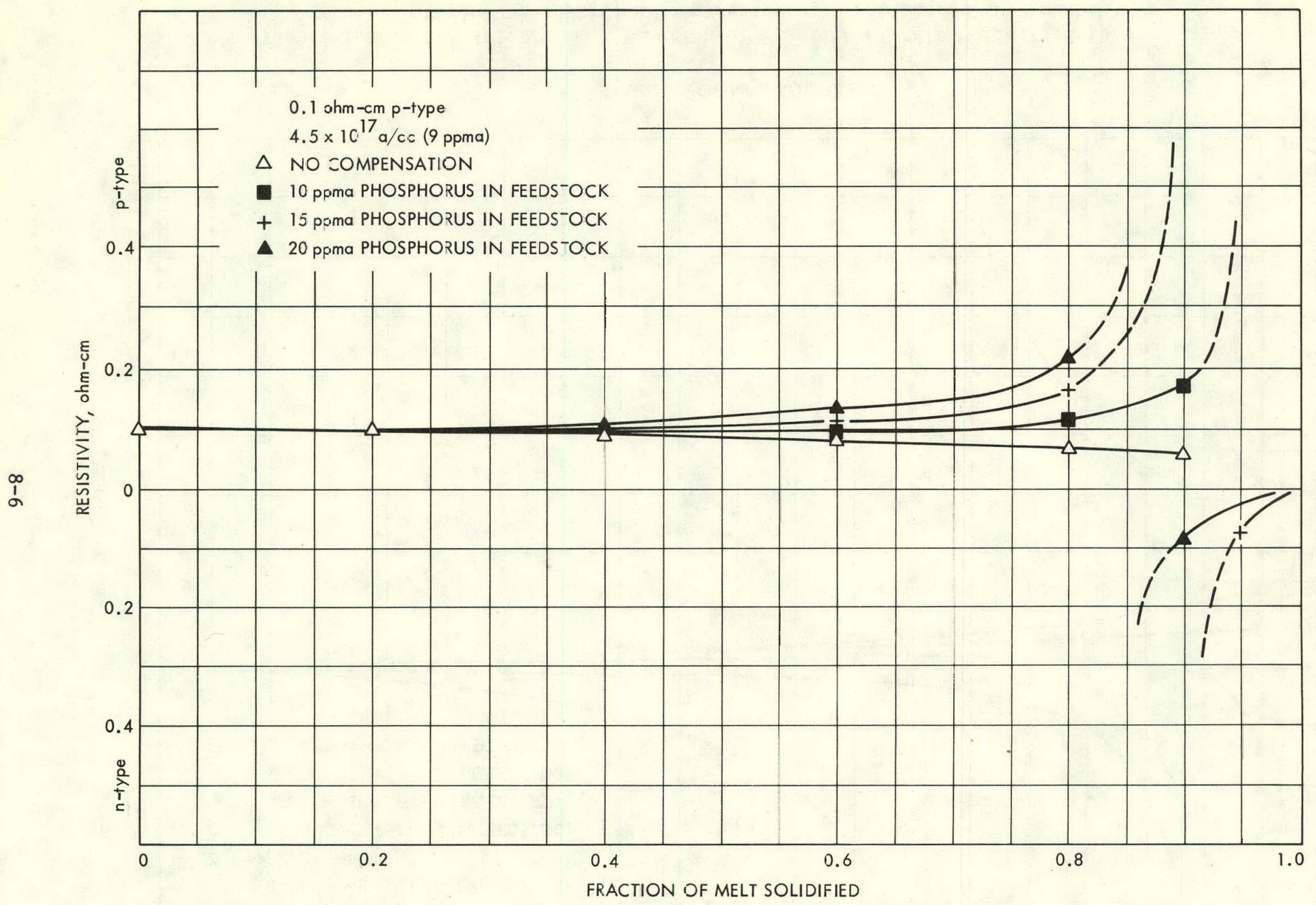

Figure 8-2d. Resistivity as a Function of Fraction of Melt solidified for Borcn-Doped Silicon Compensated with Phosphorus (0.1 ohm-cm) 


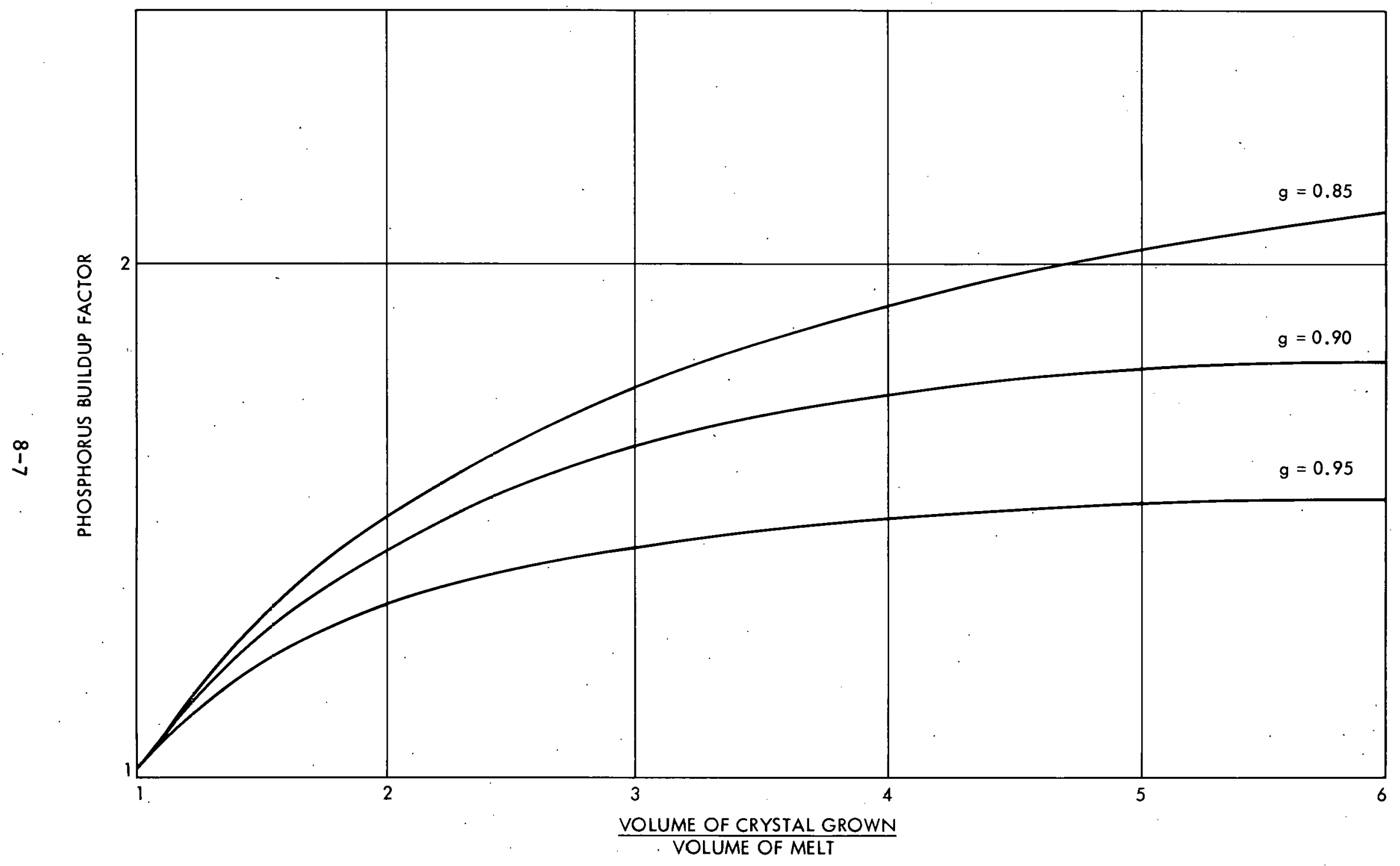

Figure 8-3. Phosphorus Buildup in Melt as a Function of the Ratio of the Volume of Crystal Grown to the Volume of the Melt 
Replenishment growth can increase the phosphorus content by about a factor of two. For $0.3 \mathrm{ohm}-\mathrm{cm}$ nominal resistivity, the tolerable phosphorus concentration is about 1 ppma for $g$ equal to 0.9 , as shown in Figures $8-1$ and 8-2c. For 5 replenishments the allowable concentration of phosphorus becomes about 0.5 ppma which corresponds to about one-fourth of the boron concentration. 
SECTION IX

CRYSTAL STRUCTURE BREAKDOWN

Another effect of impurities on solar-grade silicon is the possibility of structural breakdown during crystal growth. This result is governed by the total impurity content of the feedstock rather than by the species present. For Czochralski growth, the critical liquid impurity content $\mathrm{C}^{*}$ at which breakdown occurs can be described by an equation of the following form (see Reference 1):

$$
C^{L^{*}}=\frac{D}{m} \frac{A}{r^{1 / 2} v}-B e^{-130 V}
$$

where $D$ is the diffusion coefficient in the liquid, $m$ the 1iquidus slope, $r$ the crystal radius in centimeters, and $V$ the growth velocity in centimeters per second.

When the impurity concentration in the liquid exceeds $c^{L^{*}}$, the ingot structure degenerates and ceases to be a single crystal (see Reference 2). Using Equation (30) and the constants given in Reference 1 , the values of $\mathrm{C}^{\mathrm{L}^{*}}$ are compared with experimental values for ingots ranging in diameter from 2.5 to $8 \mathrm{~cm}$ in diameter and growth rates between 1 and $15 \mathrm{~cm} / \mathrm{h}$ as shown in Figure 9-1. The agreement is good considering the nature of the comparison. The critical breakdown concentrations typically fell in the 2000- to 5000-ppma range. As these values represent the onset of structural degradation, by referring to the impurity buildup curves shown in Figure $6-4$ it is evident that the tolerable feedstock concentration $C_{0}$ that corresponds to one Czochralski pull and $90 \%$ of the melt grown would be about one-tenth of these values; and five replenishments, about one-fiftieth of the values shown in Figure 7-4 or in the range of 200 to 500 ppma and 40 to 100 ppma, respectively.

As ingot sizes and pull rates are scaled up from the $8-\mathrm{cm}$ and $7-\mathrm{cm} / \mathrm{h}$ range, common for Czochralski growth, the impurity concentration at which structural breakdown occurs will also decrease. Figure 9-2, calculated from. Equation ( 30$)$, shows this trend where the critical breakdown concentration is given as functions of the ingot diameter and püll speed. It is possible that the upper 1 imit in the impurity concentration for these cases will be determined by crystal breakdown rather than by cell efficiency. 


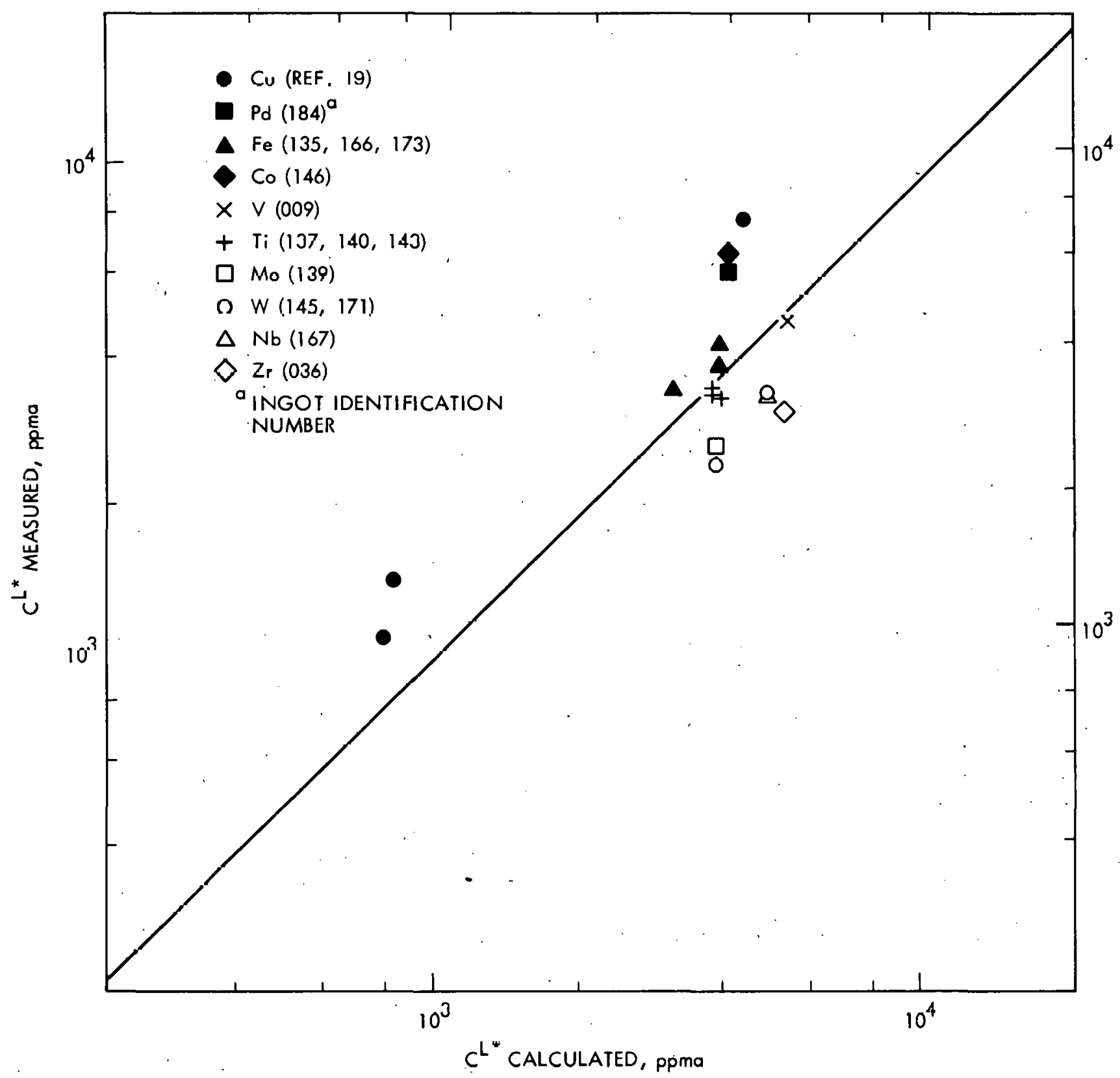

Figure 9-1. Measured and Calculated Values of the Critical Impurity Concentration, $\mathrm{CL}^{*}$, at the Start of Crysta $\perp$ structure Breakdown 


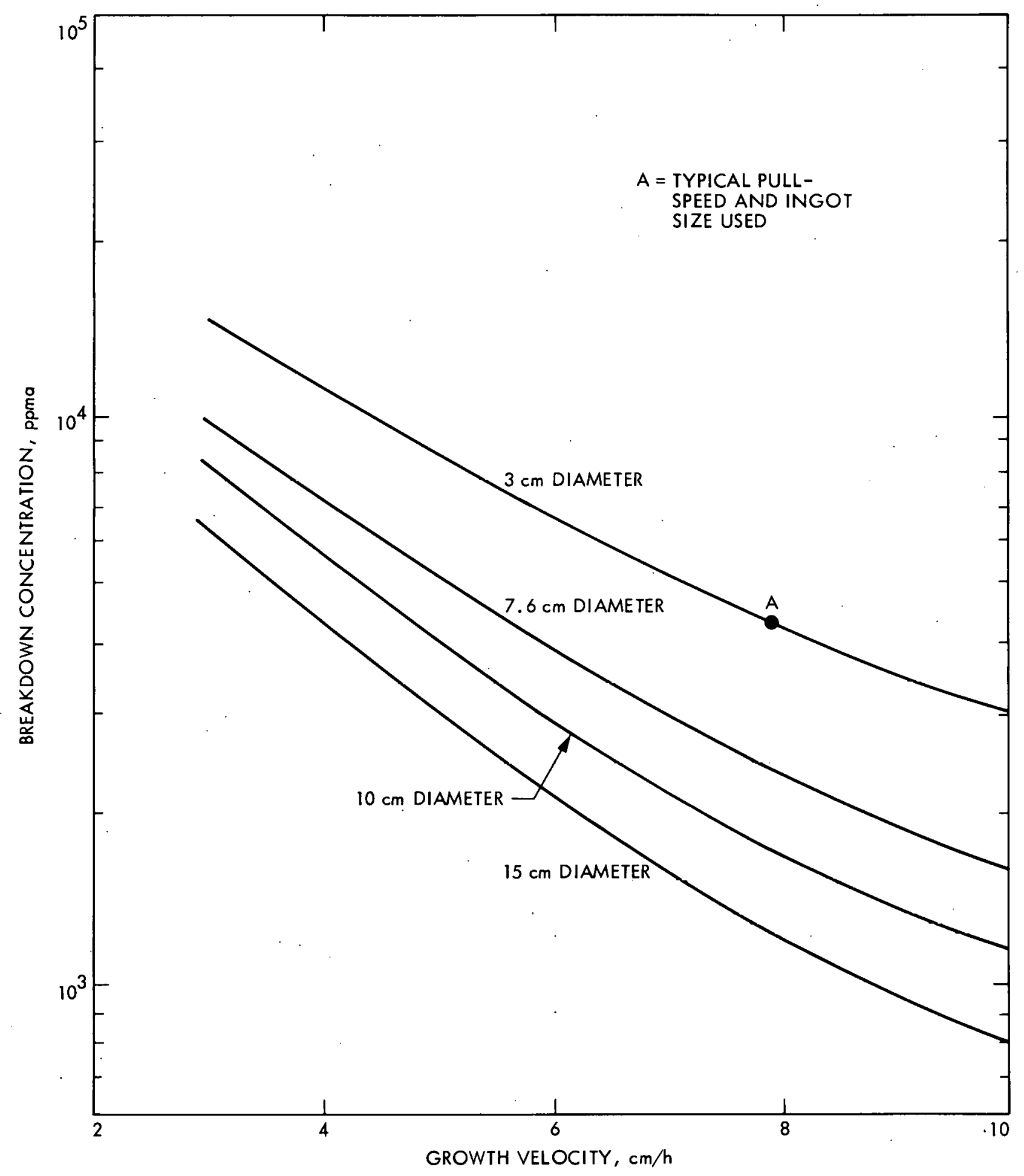

Figure 9-2. Impurity Concentration for Crystal Structure Breakdown as Functions of Pull Rate and Ingot Diameter 
SECTION $\mathrm{X}$

CONCLUSIONS

The effects of impurities on solar-cell performance are species-dependent. The effects are most severe for the elements $\mathrm{Ta}, \mathrm{Zr}, \mathrm{Mo}, \mathrm{W}, \mathrm{Nb}, \mathrm{V}$ and $\mathrm{Ti}$ where concentrations in the range of $10^{-6}$ to $10^{-5}$ ppma produce degradations in solar-cell performance of 5 to $10 \%$. $\mathrm{Cr}, \mathrm{Mn}, \mathrm{Fe}, \mathrm{Co}, \mathrm{Al}, \mathrm{Ni}$ and $\mathrm{Cu}$ have successively smaller effects, and for $\mathrm{Cu}$, the impurity concentration for a $10 \%$ degradation in cell performance is about 10 ppma.

Manufacturing processes for solar cells can be divided into two classes: (1) processes in which no redistribution of impurities in the feedstock occurs; and (2) processes that include unidirectional freezing of silicon melt, where redistribution of impurities occurs during crystal growth. The purity requirements of the silicon feedstock in the second case can be considerably relaxed compared to those in the first case. The processes included in the first case are edge-defined film growth, silicon-on-ceramic, and various chemical vapor deposition processes. The processes included in the second case are Czochralski growth, dendritic web, and the ingot casting method.

Boron and phosphorus primarily alter the resistivity and the yield of usable silicon. The tolerable boron concentration in silicon feedstock is about 2 ppma, which corresponds to a resistivity of about $0.3 \mathrm{ohm}-\mathrm{cm}$. Compensation by phosphorus limits the yield of usable silicon and for $0.3 \mathrm{ohm}-\mathrm{cm}-$ material the tolerable phosphorus impurity concentration is about $0.5 \mathrm{ppma}$ for a yield of $90 \%$ usable silicon crystal.

There is a limit to the total impurity concentration in silicon feedstock caused by crystal structure breakdown during growth. This effect is species independent, but depends on the rate of growth and size of the crystal grown.

The electrical effects, efficiency, and resistivity are dominant in the determination of tolerable concentrations of impurities in the silicon feedstock for all impurities studies. However, if faster growth rates and larger crystal diameters than presently used are developed, crystal growth limitations may occur.

A solar-grade silicon can be defined for a specific manufacturing process or type of process only. 
1. Hopkins, R. H., Davis, J. R., Rohatgi, A., Campbe11, R. B., Blais, P, D., Rai-Choudhury, P., Stapleton, R. E., Mollenkopf, H. C., McCormick, J. R., Effect of Impurities and Processing on Silicon Solar Cells; Phase III Summary and 17th Quarterly Report, Volume 1: Characterization Methods for Impurities in Silicon and Impurity Effects Data Base; Volume 2: Analysis of Impurity Behavior, Westinghouse R\&D Center, Pittsburgh, Pennsylvania, DOE/JPL-954331, 1980.

2. Hopkins, R. H., Davis, J. R., Blais, P. D., Rohatgi, A., Rai-Choudhury, P., Hanes, M. H., McCormick, J. R., Effect of Impurities and Processing on Silicon Solar Ce11s; Phase II Summary and 11th Quarterly Report, Westinghouse R\&D Center, Pittsburgh, Pennsylvania, DOE/JPL-954331, 1978.

3. Hopkins, R. H., Davis, J. R., Rai-Choudhury, P., Blais, P. D., McHugh, J. P., Seidensticker, R. G., McCormick, J. R., Silicon Materials Task of the Low-Cost Solar Array Project (Part 2); 5th Quarterly Report and Summary, ERDA/JPL-954331, 1977.

4. Study of the Effects of Impurities on the Properties of Silicon Materials and Performance of Silicon Solar Cells; First Technical Report, C. T. Sah Associates, DOE/JPL 954685, Apri1 1978.

5. Study of the Effects of Impurities on the Properties of Silicon Materials and Performance of Silicon Solar Cells; Second Technical Report, C. T. Sah Associates, DOEE/JPL 954685, March 1979.

6. Study of the Effects of Impurities on the Properties of Silicon Materials and Performance of Silicon Solar Cells; Third Technical Report, C. T. Sah Associates, DOE/JPL 954685, February 1980.

7. Study of the Effects of Impurities on the Properties of Silicon Materials and Performance of Silicon Solar Cells; Fourth Technical Report, C. T. Sah Associates, DOE/JPL 954685, March 1981.

8. Othmer, S. and Chen, S. C., Silicon Materials Task of the Low-Cost Solar Array Project; Draft.Final Report, Northrop Research and Technology Center, ERDA/JPL-954614, 1977.

9. Gutsche, H. W. and Hil1, D. E., Determination of a Definition of Solar Grade Silicon; Final Report, Monsanto Research Corporatinn, ERDA/JPL 954338, September 1976.

10. Uno, $F .$, Analysis of Effects of Impurities Intentionally Incorporated into Silicon; Final Report, Spectrolab, Inc., ERDA/JPL-954694, 1978.

11. Wohlgemuth, J. H. and Giuliano, M. N., Analysis of the Effects of Impurities in Silicon; Solarex Corporation, DOE/JPL-955307, 1980.

12. Sirtl, E. and Adler, A., Z. Metalk. 52, 529, 1961. 
13. Lang, D. V., Journal of Applied Physics, Vol. 45, 7 July 1974.

14. Mass Spectrometer Type MS-7 Performance Characteristics, Associated Electrical Industries, Ltd.

15. Multi-Element Survey Analysis of Silicon, Data Sheet, General Activation Analysis, Inc.

16. Lindholm, F. A., Fossum, J. G., and Burgess, E. L., "Application of the Superposition Principle to Solar-Ce11 Analysis,". Transactions on Electron Devices, Vol. ED-26, No. 3, March 1979.

17. Iles, P. A., and Green, IEEE Transactions, ED-23, No. 1, January 1970; Dunbar, P. M. and Hauser, J. R., Solid State Electronics, Vol. 19, Pp. 95-102, 1976; also presented at the 8th Photovoltaic Specialists' Conference, 1970 .

18. Irvin, J. C., Bell Systems Technical Journal, Vol. XLI, No. 2, 1962 .

19. Digges, T. C., Virginia Semiconductor Corporation, unpublished results, 1979. 
APPENDIX A

NORMALIZED EFFICIENCY AS A FUNCTION OF THE CONCENTRATION OF SPECIFIC IMPURITIES IN UNITS OF $\mathrm{N}_{\text {OX }}$

A-1 


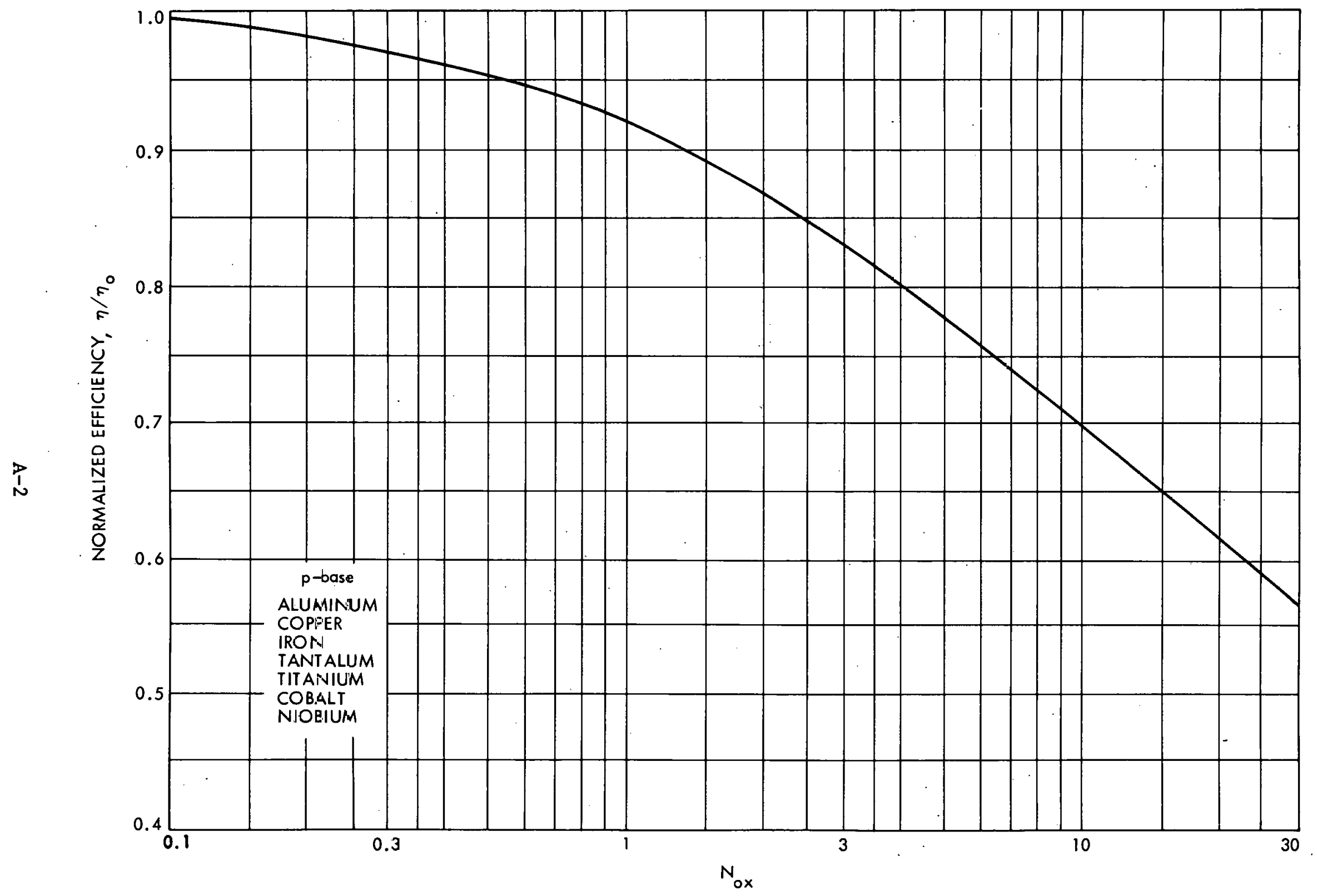

Figure A-1. Normalized Efficiency as a Function of Impurity Concentration in Units of $N_{0 x}$ 


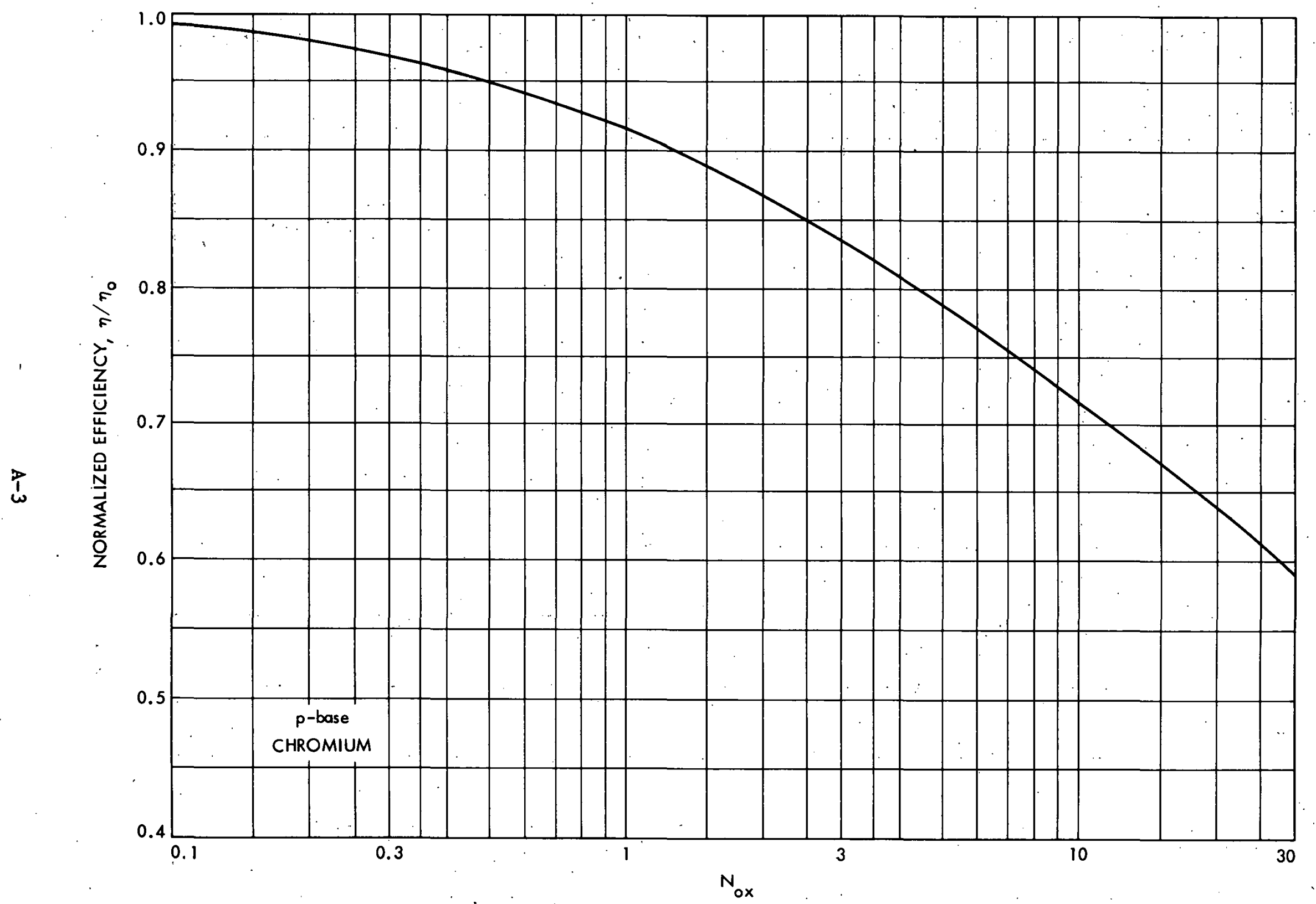

Figure A-2. Normalized Efficiency as a Function of Impurity Concentration in Units of $N_{\text {ox }}$ 


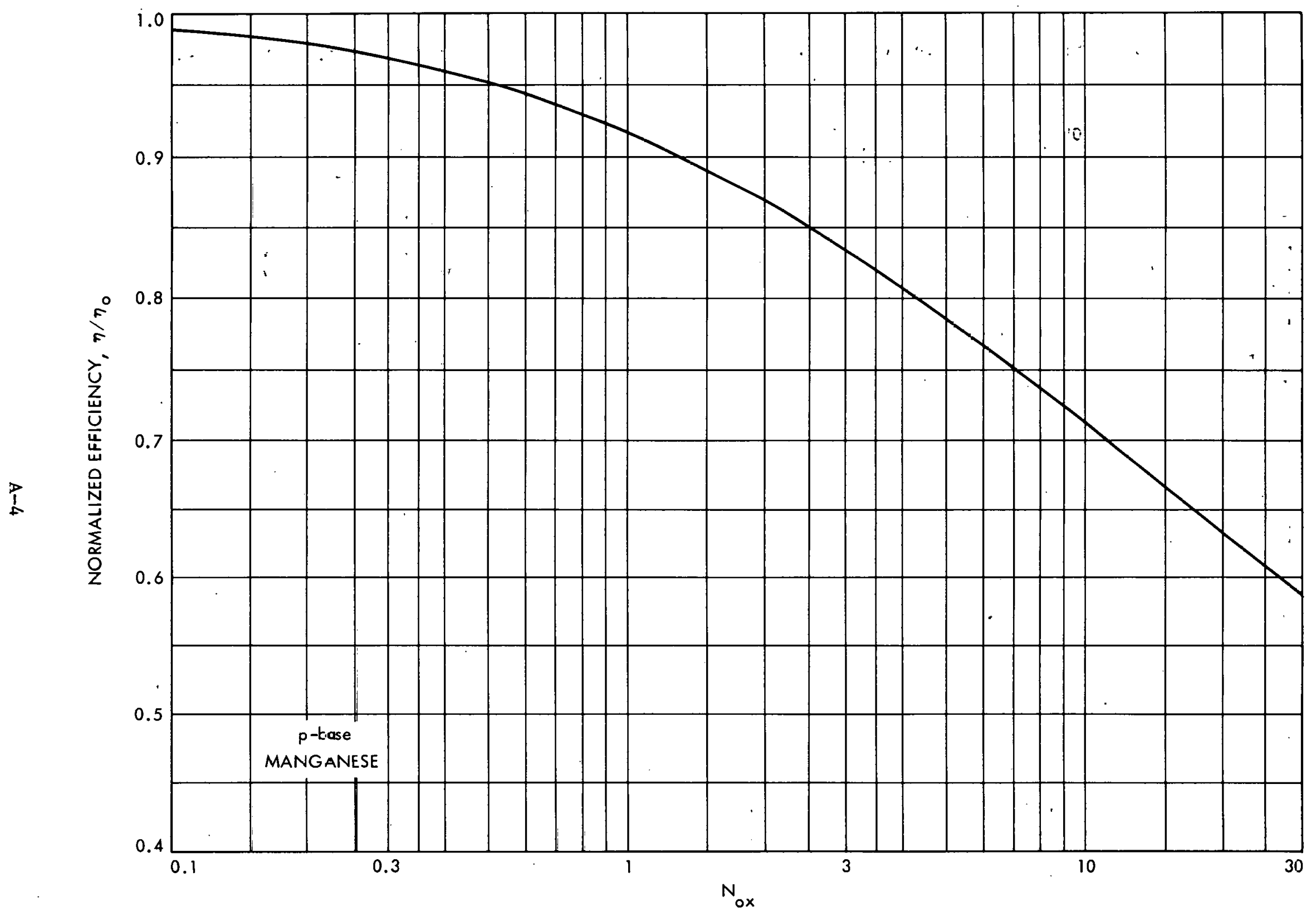

Figure A-3. Normalized Efficiency as a Function of Impurity Concentration in Units of $N_{o x}$ 


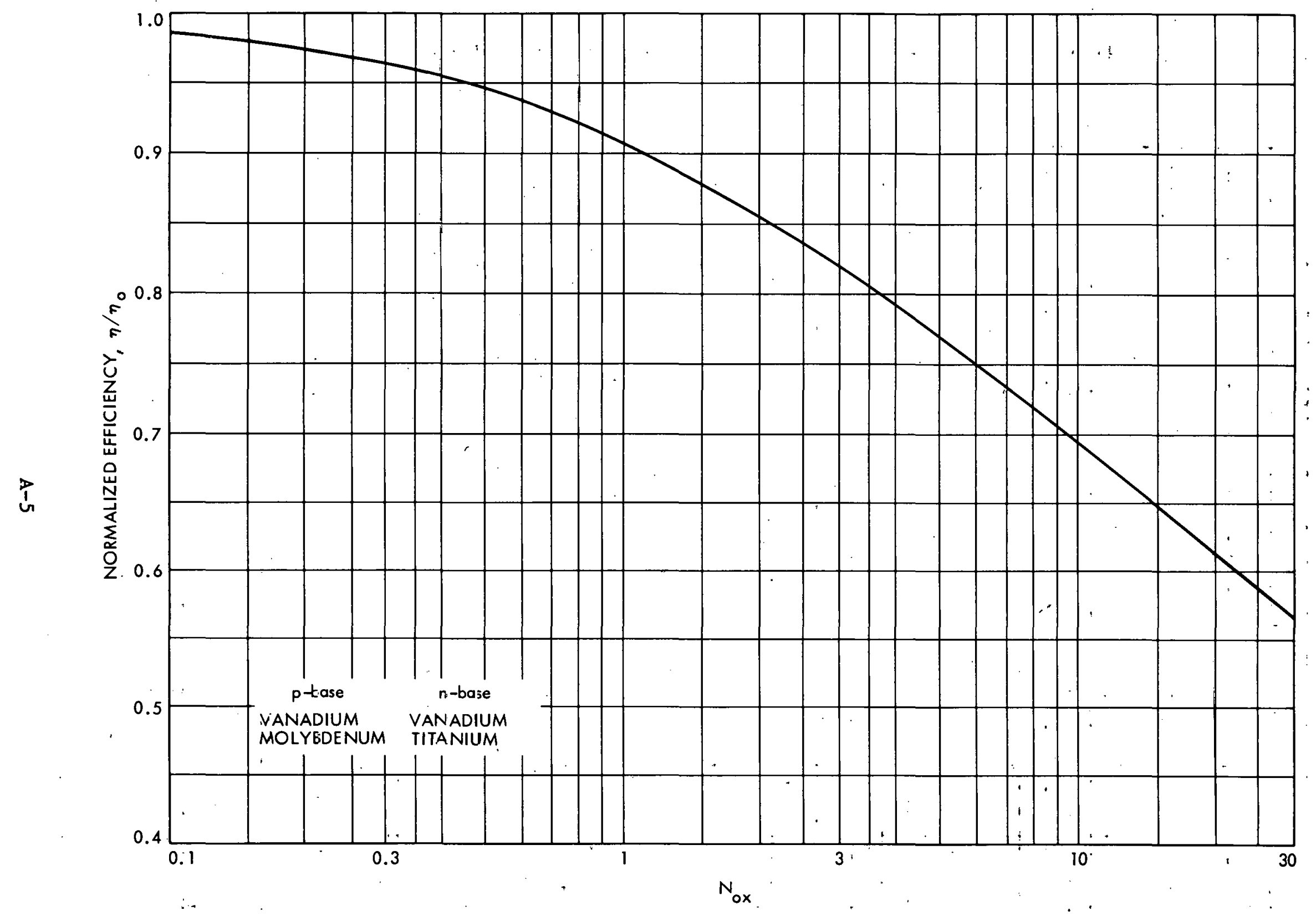

Figure A-4. Normalized Efficiency as a Function of Impurity Concentration in Units of $\mathrm{N}_{\text {ox }}$ 


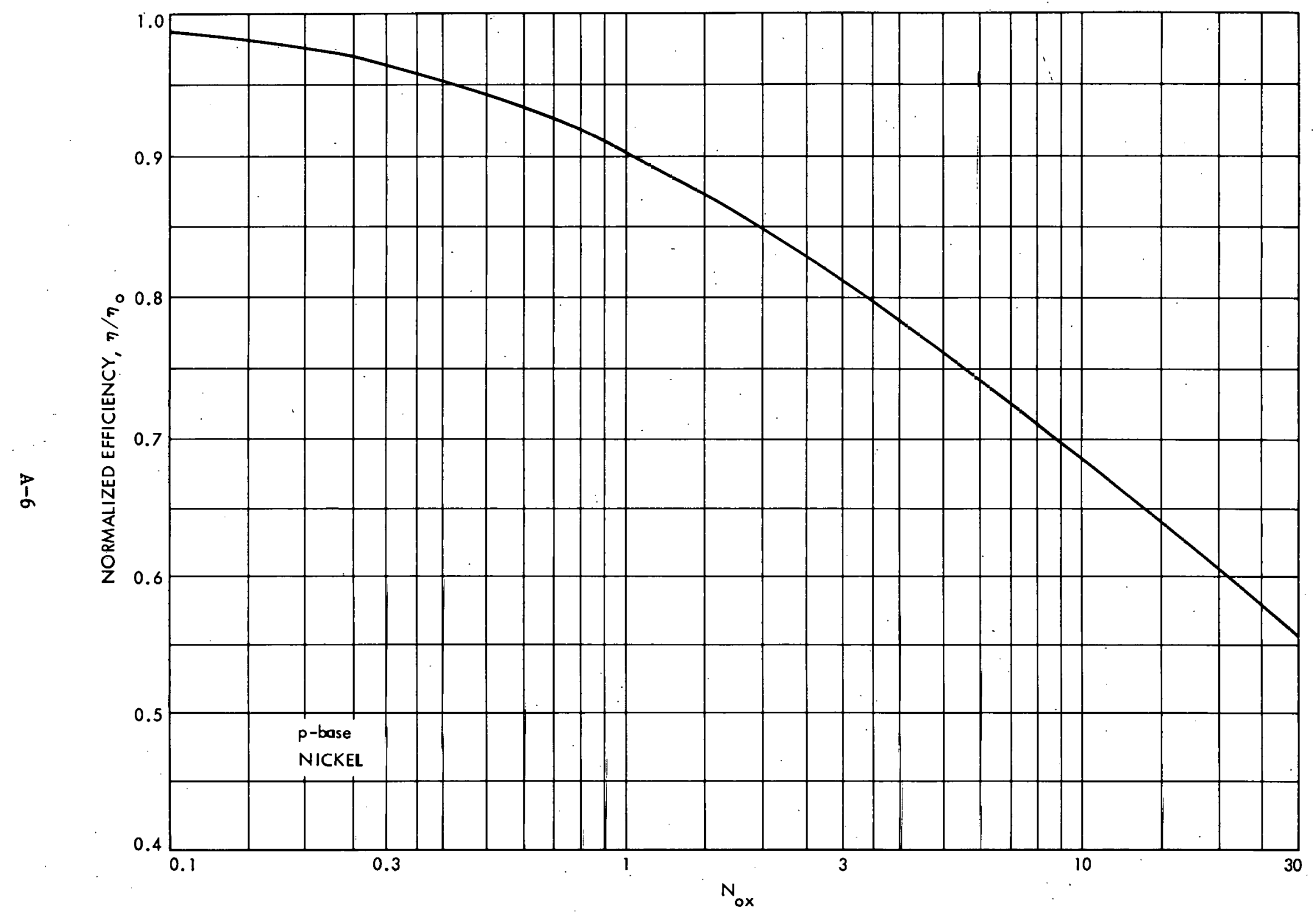

Figure A-5. Normalized Efficiency as a Function of Impurity Concentration in Units of $\mathrm{N}_{\mathrm{ox}}$ 


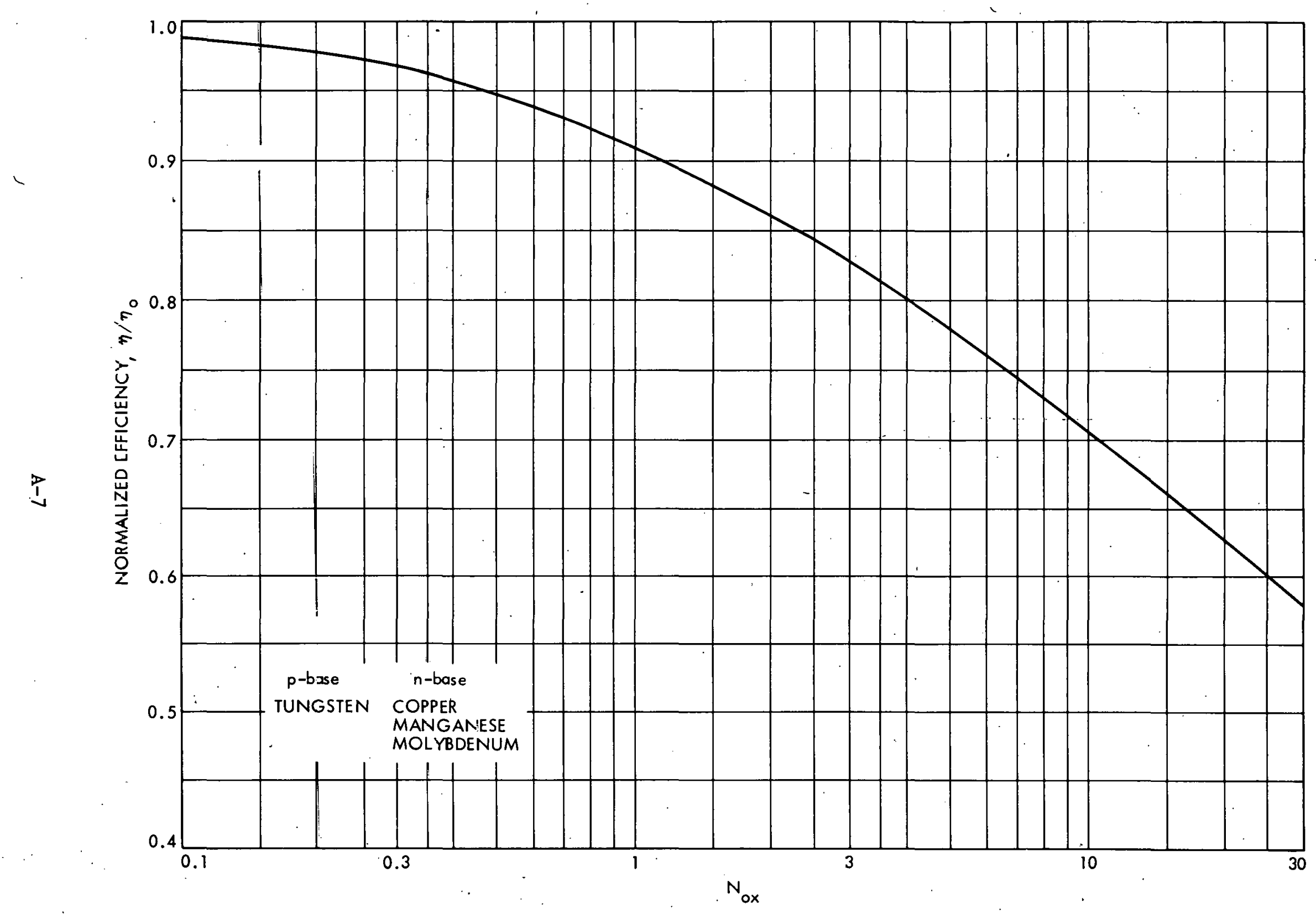

Figure A-6. Normalized Efficiency as a Function of Impurity Concentration in Units of $\mathrm{N}_{\mathrm{ox}}$ 


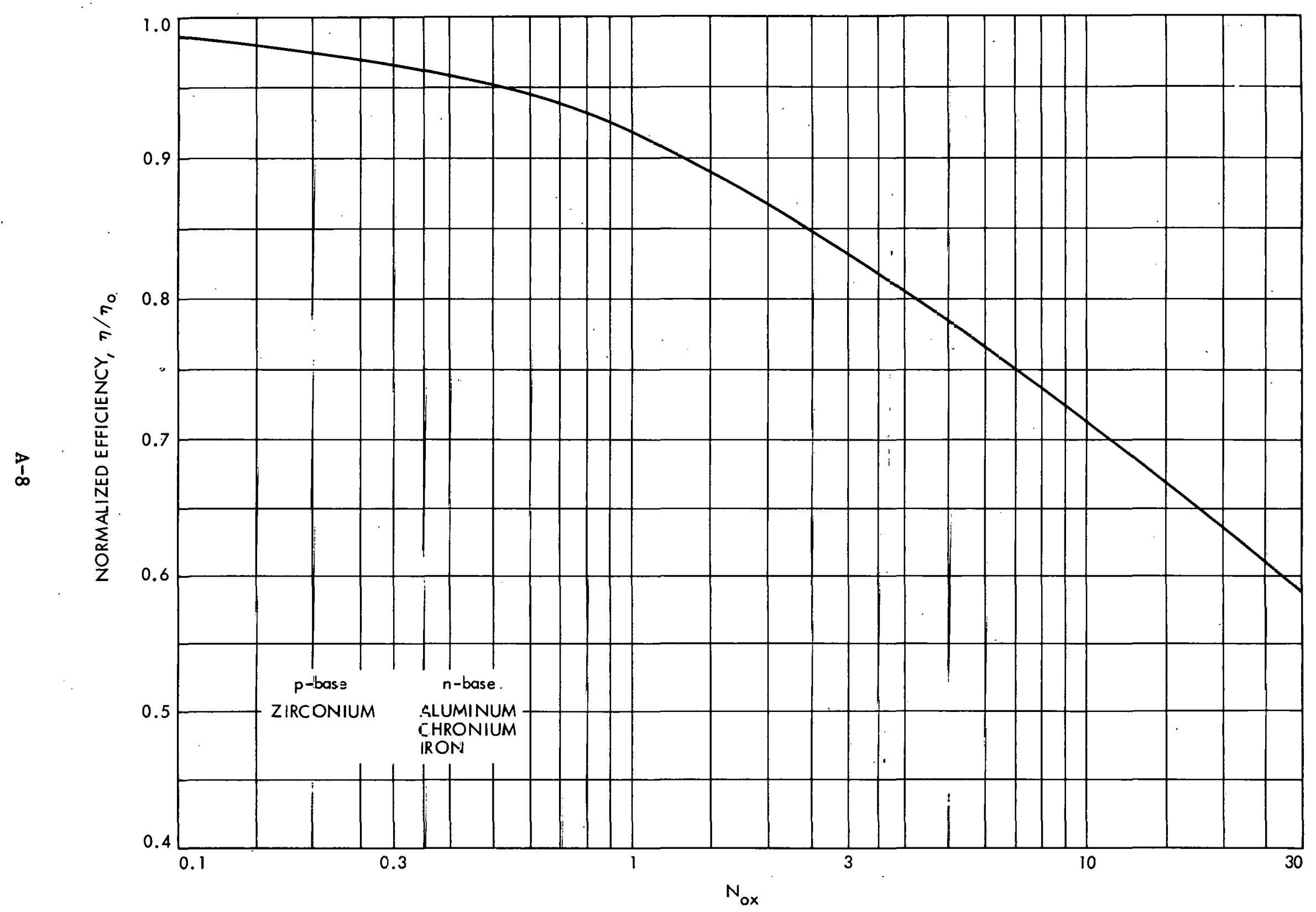

Figure A-7. Normalized Efficiency as a Function of Impurity Concentration in Units of $\mathrm{N}_{\mathrm{ox}}$ 